\title{
Ana Cláudia Tedesco Zanchi
}

Estudo das alterações no desenvolvimento, no comportamento e na bioquímica cerebral de ratos machos adultos expostos à poluição atmosférica ambiental durante a fase intra-uterina e o período de lactação

Tese apresentada à Faculdade de Medicina da Universidade de São Paulo para a obtenção do título de Doutor em Ciências.

Área de concentração: Fisiopatologia Experimental Orientadora: Profa. Dra. Angela Cristina do Valle

São Paulo 


\section{Ana Cláudia Tedesco Zanchi}

Estudo das alterações no desenvolvimento, no comportamento e na bioquímica cerebral de ratos machos adultos expostos à poluição atmosférica ambiental durante a fase intra-uterina e o período de lactação

Tese apresentada à Faculdade de Medicina da Universidade de São Paulo para a obtenção do título de Doutor em Ciências.

Área de concentração: Fisiopatologia Experimental Orientadora: Profa. Dra. Angela Cristina do Valle - FMUSP Co-orientador: Prof. Dr. Paulo Hilário do Nascimento Saldiva - FMUSP

São Paulo 


\title{
Dados Internacionais de Catalogação na Publicação (CIP)
}

\author{
Preparada pela Biblioteca da
}

Faculdade de Medicina da Universidade de São Paulo

Creprodução autorizada pelo autor

Zanchi, Ana Claudia Tedesco

Estudo das alterações no desenvolvimento, no comportamento e na bioquímica cerebral de ratos machos adultos expostos à poluição atmosférica ambiental durante a fase intra-uterina e o período de lactação. / Ana Claudia Tedesco Zanchi. -- São Paulo, 2010.

Tese (doutorado)--Faculdade de Medicina da Universidade de São Paulo para obtenção do título de Doutor em Ciências.

Área de concentração: Fisiopatologia Experimental.

Orientadora: Angela Cristina do Valle.

Descritores: 1.Estresse oxidativo 2.Sistema nervoso central 3.Memória 4.Atividade motora 5.Comportamento espacial 6.Material particulado 7.Poluição do ar 8.Poluição ambiental 9.Efeitos tardios da exposição pré-natal 10.Comportamento animal 
Dedico esse trabalho a minha mãe Marinice e irmã Marta.

Dedico esse trabalho as queridas professoras Claudia Ramos Rhoden e Rosani Bernardi. 


\section{Agradecimentos}

A Deus por me mostrar o caminho nos momentos mais difíceis,

A minha mãe e irmã pela paciência, carinho e amor,

Ao meu querido Leandro, pelo apoio e amor incondicionais,

Ao professor Saldiva pelos ensinamentos, por ter acreditado na gente aqui do sul e por ser "tri legal",

A professora Claudia Ramos Rhoden, minha mentora, amiga e companheira de todas as horas, que me ensinou tudo o que eu sei sobre pesquisa,

A professora Rosane Bernardi por me ajudar a desbravar os caminhos da memória, pela amizade, carinho, apoio e companheirismo,

A professora Elia Garcia Caldini, pelo apoio e atenção durante o curso,

A professora Mariângela Macchione pelo carinho,

A querida amiga Nilsa, pela amizade, companheirismo e por estar sempre ao meu lado,

A Mariana Matera Veras pela amizade e ensinamentos estereológicos;

A Neusa que sempre esteve por perto quando precisava,

Aos queridos amigos do laboratório de Estresse Oxidativo e Poluição Atmosférica:

Bel. Juliana Klieman Chagas, Bel. Lucas Sagrillo Fagundes, Bel. Maria Fernanda 
Hornos Carneiro, Bel. Roberto Marques Damiani, Msc. Graziele Halmenschlager, Dra. Giovana Gamaro, Fernando Teixeira, Gabriela Chagas, Lucianna Schmitt, Marcella Ody Piva,

A Sônia Fagundes por estar sempre sorrindo e pronta a nos ajudar quando precisamos, E a todas as pessoas que participaram dessa jornada, muito obrigada! 
"A felicidade não se resume na ausência de problemas, mas sim na sua capacidade de lidar com eles."

"A mente que se abre a uma nova idéia jamais volta ao seu tamanho original".

Albert Einstein 
Esta tese está de acordo com as seguintes normas em vigor no momento de sua publicação:

Referências: adaptado das Normas da Associação Brasileira de Normas Técnicas 2009 (Brasil)

Universidade de São Paulo. Faculdade de Medicina. Serviço de Biblioteca e documentação. Guia de apresentação de dissertações, teses e monografias. Elaborado por Anneliese Carneiro da Cunha, Maria Júlia de A.L. Freddi, Maria F. Crestana, Mannalva de Souza Aragão, Suely Campos Cardoso, Valéria Vilhena, 2a Ed., São Paulo: Serviço de Biblioteca e documentação.

Abreviaturas dos títulos dos periódicos de acordo com List of Journals Indexed in Index Medicus. 


\section{Sumário}

$\begin{array}{ll}\text { Lista de abreviaturas } & 12\end{array}$

$\begin{array}{ll}\text { Lista de figuras } & 16\end{array}$

$\begin{array}{ll}\text { Lista de gráficos } & 18\end{array}$

$\begin{array}{ll}\text { Lista de tabelas } & 20\end{array}$

$\begin{array}{ll}\text { Resumo } & 21\end{array}$

$\begin{array}{ll}\text { Abstract } & 23\end{array}$

1 INTRODUÇÃO

1.1 Aspectos gerais sobre a poluição atmosférica 25

1.2 Poluição do ar e efeitos sobre a saúde 28

1.2.1 Efeitos sobre o sistema cardiorrespiratório 28

1.2.2 Efeitos relacionados à exposição aos poluentes nas fases pré e pós-natal 31

1.2.3 Efeitos no sistema nervoso central (SNC) 33

1.2.4 Exposição a substâncias neurotóxicas e processos cognitivos 35

1.3 Desenvolvimento do SNC 38

1.4 Aspectos gerais sobre as memórias 46

1.4.1 Estruturas cerebrais envolvidas na formação das memórias 48

1.4.2 Mecanismos de formação das memórias 52

1.4.3 Mecanismos moleculares e rotas bioquímicas para a formação das 54 memórias

1.4.4 Modelos animais para estudo das memórias 58

$\begin{array}{ll}\text { 1.5 Estresse oxidativo } & 60\end{array}$

1.5.1 Toxicidade do oxigênio $\left(\mathrm{O}_{2}\right) \quad 60$

1.5.2 Tipos de espécies ativas de oxigênio 62

1.5.3 Reatividade das espécies ativas de oxigênio 64 
1.5.6 Estresse oxidativo, doenças neurodegenerativas e poluição do ar 73

$\begin{array}{ll}2 \text { JUSTIFICATIVA } & 76\end{array}$

3 OBJETIVOS

$\begin{array}{ll}3.1 \text { Objetivo geral } & 77\end{array}$

$\begin{array}{ll}3.2 \text { Objetivos específicos } & 77\end{array}$

4 MATERIAIS E MÉTODOS

4.1 Desenho experimental 81

4.2 Câmaras de exposição 86

4.3 Testes comportamentais 89

4.3.1 Teste do reconhecimento espontâneo de objetos (SORT) 89

4.3.2 Labirinto de Morris modificado 91

4.4 Análises do estresse oxidativo 92

4.4.1 Determinação da lipoperoxidação 92

4.4.2 Determinação da atividade da superóxido dismutase (SOD) 95

4.4.3 Determinação da catalase (CAT) 95

4.4.4 Determinação da concentração da glutationa total (GSHt) 96

4.5 Determinação dos elementos traço tóxicos e essenciais no sangue total 99

4.6 Análises histológicas por técnicas estereológicas 97

4.6.1 Córtex 98

$\begin{array}{ll}\text { 4.6.2 Hipocampo } & 100\end{array}$

$\begin{array}{ll}\text { 4.6.3 Estriado } & 101\end{array}$

$\begin{array}{ll}\text { 4.6.4 Coloração } & 102\end{array}$ 
4.6.5 Obtenção das imagens e análises estereológicas do córtex cerebral, 103 estriado e hipocampo

4.6.6 Quantificação do número de neurônios e neuroglia no córtex e estriado 105

4.6.7 Quantificação de neurônios e neuroglia na região CA1 do hipocampo 106

4.6.8 Fórmulas para cálculo do número de neurônios e neuroglia das 108 estruturas encefálicas analisadas

$\begin{array}{ll}4.7 \text { Análise estatística } & 109\end{array}$

$\begin{array}{ll}5 \text { RESULTADOS } & 111\end{array}$

5.1 Avaliação do desenvolvimento e caracterização da prole 111

$\begin{array}{ll}5.2 \text { Testes comportamentais } & 113\end{array}$

5.2.1 Teste do reconhecimento espontâneo de objetos (SORT) 113

$\begin{array}{ll}\text { 5.2.2 Labirinto de Morris modificado } & 116\end{array}$

$\begin{array}{ll}5.3 \text { Análises do estresse oxidativo } & 118\end{array}$

5.4 Determinação dos elementos traço tóxicos e essenciais no sangue total 123

$\begin{array}{ll}5.5 \text { Análises histológicas por técnicas estereológicas } & 126\end{array}$

$\begin{array}{ll}\text { 5.5.1 Volume total das estruturas encefálicas } & 126\end{array}$

$\begin{array}{ll}\text { 5.5.2 Contagem de neurônios e neuroglia } & 128\end{array}$

$\begin{array}{ll}\text { 5.5.2.1 Córtex } & 128\end{array}$

$\begin{array}{ll}\text { 5.5.2.2 Hipocampo } & 130\end{array}$

$\begin{array}{ll}\text { 5.5.2.3 Estriado } & 132\end{array}$

6 DISCUSSÃO

$\begin{array}{ll}7 \text { CONCLUSÃO } & 150\end{array}$

8 REFERÊNCIAS BIBLIOGRÁFICAS

$\begin{array}{lr}\text { APÊNDICE A } & 168\end{array}$ 


\section{Lista de abreviaturas}

Aco acetilcolina

ADN ácido desóxi-ribonucléico

Al alumínio

AMPA ácido alfa-amino-3-hidróxi-5-metil-4-isoxazol-propiônico)

AMPc monofosfato de adenosina cíclico

ARNm ácido ribonucléico mensageiro

ATP trifosfato de adenosina

A 442 peptídeo beta amilóide formado por 42 aminoácidos

BHE barreira hematoencefálica

BNDF brain-derived neutrophic factor (fator neurotrófico encefálico)

$\mathrm{Br}$ bromo

Ca cálcio

$\mathrm{Ca}^{+2}$ íon cálcio

CAF câmara ar filtrado

CaMKII cálcio calmodulina II

CANF câmara ar não filtrado

Cl cloro

CO monóxido de carbono

Co cobalto

COX2 ciclooxigenase 2

Cr cromo

CREB-P responsive element binding protein (fator de transcrição do ADN presente nos núcleos das células) 
Cu cobre

DA dopamina

DDAH distúrbio do déficit de atenção e hiperatividade

DHA dihidroascorbato

EAO espécies ativas de oxigênio

EO estresse oxidativo

ERK extracellular signal-regulated kinase (proteína cinase extracelular sinalizadora)

Fe ferro

GABA ácido gama-aminobutírico

GAP-43 proteína reguladora da liberação de glutamato

GPx glutationa peroxidase

GSH glutationa reduzida

GSHt glutationa total

GSSG disulfeto de glutationa (glutationa oxidada)

$\mathbf{H}^{+}$próton

$\mathrm{H}_{2} \mathrm{O}_{2}$ peróxido de hidrogênio

HAP hidrocarbonetos aromáticos policíclicos

HEPA high efficiency particulate air (filtro de alta eficiência para material particulado em suspensão no ar)

$\mathrm{HO}_{2}{ }^{\bullet}$ radical hidroperoxil

IL-1ß interleucina 1 beta

IL-6 interleucina 6

K potássio

$\mathbf{K}^{+}$íon potássio

$\mathbf{L O}_{2}{ }^{\bullet}$ radical peroxil 
MAPK agentes mitógenos

Mg magnésio

$\mathbf{M g}^{+2}$ íon magnésio

Mn manganês

MnSOD superóxidodismutase manganês

MP material particulado

$\mathrm{mV}$ milivolt

NA noradrenalina

$\mathrm{Na}^{+}$íon sódio

NADPH nicotinamida adenina dinucleotídeo fosfato oxidase

Ni níquel

NMDA N-metil-D-aspartato

NO óxido nítrico

$\mathrm{NO}_{2}$ dióxido de nitrogênio

$\mathrm{O}_{2}$ oxigênio

$\mathrm{O}_{2}^{-\bullet}$ ânion radical superóxido

$\mathrm{O}_{3}$ Ozônio

${ }^{1} \mathbf{O}_{\mathbf{2}}$ oxigênio singlet

$\mathrm{OH}^{-\bullet}$ radical hidroxil

P fósforo

$\mathbf{P b}$ chumbo

PKA proteína cinase $\mathrm{A}$

PKC proteína cinase C

PKG proteína cinase G

S enxofre 
Se selênio

SDA semihidroascorbato

\section{5-HT serotonina}

Si silício

SNC sistema nervoso central

$\mathrm{SO}_{2}$ dióxido de enxofre

SOD superóxido dismutase

SORT spontaneous object recognition test (teste de reconhecimento espontâneo de objetos)

SUR sistema uniforme randomizado

Ti titânio

TNF $\alpha$ alfa tumoral necrosis factor (fator de necrose tumoral alfa)

V vanádio

Zn zinco

CuZnSOD superóxido dismutase cobre-zinco 


\section{Lista de figuras}

Figura 1: Vista da Avenida Castelo Branco em Porto Alegre.

Figura 2: Representação esquemática das terminações nervosas sensoriais do epitélio nasal (seta vermelha).

Figura 3: Representação esquemática do desenvolvimento inicial do sistema nervoso.

Figura 4: A: Mapa das principais áreas cerebrais envolvidas no processamento das memórias declarativas.

Figura 5: Vista da formação hipocampal em corte coronal.

Figura 6. Representação esquemática das reações de redução incompletas do oxigênio à $\mathrm{H}_{2} \mathrm{O}$.

Figura 7: Representação esquemática das etapas da lipoperoxidação de membranas celulares.

Figura 8: Representação esquemática das reações de oxi-redução (1 e 2); reações de Fenton (3 e 4).

Figura 9: Representação esquemática da reação de dismutação catalisada pela SOD.

Figura 10: Representação esquemática da reação de oxidação da glutationa e redução do $\mathrm{H}_{2} \mathrm{O}_{2}$ catalisada pela GPx.

Figura 11: Representação esquemática da reação de detoxificação de lipoperóxido pelo $\alpha$-tocoferol.

Figura 12: Representação esquemática do desenho experimental.

Figura 13: Representação esquemática das câmaras de exposição.

Figura 15: Representação esquemática do Teste do Reconhecimento Espontâneo de Objetos.

Figura 16: Representação esquemática do labirinto de Morris.

Figura 17: Representação esquemática do método Fractionator - o córtex foi seccionado em fatias de $2 \mathrm{~mm}$ de espessura em série e novamente em fragmentos menores para gerar cortes (SUR).

Figura 18: Método utilizado para a obtenção dos cortes do córtex de $2 \mathrm{~mm}$ de espessura em série.

Figura 19: Representação esquemática - método disector - 2 pares de cortes de 5 $\mu \mathrm{m}$ seriados na mesma lâmina com um intervalo de $150 \mu \mathrm{m}$ entre eles 
Figura 20: Cortes do hipocampo no plano longitudinal.

Figura 21: Representação - método disector - 2 pares de cortes de $5 \mu \mathrm{m}$ seriados na mesma lâmina com um intervalo de $100 \mu \mathrm{m}$ entre eles.

Figura 22: Representação esquemática - método disector - 2 pares de cortes de 5 $\mu \mathrm{m}$ seriados na mesma lâmina com um intervalo de $150 \mu \mathrm{m}$ entre eles.

Figura 23: Fotografia ilustrativa de corte de córtex cerebral de rato exposto à poluição atmosférica ambiental após o período de desmame até 150 dias de vida (grupo FNF) corado com azul de toluidina, $5 \mu \mathrm{m}$.

Figura 24: Fotografia ilustrativa de hipocampo de rato exposto à plouição atmosférica a nível ambiental desde a vida intra-uterina até 150 dias de vida (grupo NF) corado com azul de toluidina, $5 \mu \mathrm{m}$.

Figura 25: Fotografia ilustrativa de estriado de rato exposto à poluição atmosférica ambiental após o período de desmame até 150 dias de vida (grupo FNF) corado com azul de toluidina, $5 \mu \mathrm{m}$. 


\section{Lista de gráficos}

Gráfico 1: Representação gráfica do índice de habituação de ratos machos adultos expostos ou não à poluição atmosférica a nível ambiental durante a fase intrauterina e o período de lactação. Grupos experimentais: F (filtrado), NFF (não filtrado/filtrado), FNF (filtrado/não filtrado), NF (não filtrado).

Gráfico 2: Representação gráfica do índice de discriminação de ratos machos adultos expostos ou não à poluição atmosférica a nível ambiental durante a fase intra-uterina e o período de lactação. Grupos experimentais: F (filtrado), NFF (não filtrado/filtrado), FNF (filtrado/não filtrado), NF (não filtrado).

Gráfico 3: Representação gráfica dos tempos de latência para encontrar a plataforma de escape a partir de diferentes posições no labirinto de Morris de ratos adultos expostos ou não à poluição atmosférica a nível ambiental durante a fase intra-uterina e o período de lactação. Grupos experimentais: F (filtrado), NFF (não filtrado/filtrado), FNF (filtrado/não filtrado), NF (não filtrado).

Gráficos 4: Representação gráfica da concentração de MDA, atividades das enzimas SOD e catalase e da concentração de glutationa total no córtex cerebral de ratos adultos expostos ou não à poluição atmosférica a nível ambiental durante a fase intra-uterina e o período de lactação. Grupos experimentais: F (filtrado), NFF (não filtrado/filtrado), FNF (filtrado/não filtrado), NF (não filtrado).

Gráficos 5: Representação gráfica da concentração de MDA, atividades das enzimas SOD e catalase e da concentração de glutationa total no hipocampo cerebral de ratos machos adultos expostos ou não à poluição atmosférica a nível ambiental durante a fase intra-uterina e o período de lactação. Grupos experimentais: $F$ (filtrado), NFF (não filtrado/filtrado), FNF (filtrado/não filtrado), NF (não filtrado).

Gráficos 6: Representação gráfica da concentração de MDA, atividades das enzimas SOD e catalase e da concentração de glutationa total no estriado de ratos machos adultos expostos ou não à poluição atmosférica a nível ambiental durante a fase intra-uterina e o período de lactação. Grupos experimentais: F (filtrado), NFF (não filtrado/filtrado), FNF (filtrado/não filtrado), NF (não filtrado).

Gráfico 7: Representação gráfica do número de células (neurônios e neuroglia) do córtex cerebral de ratos adultos expostos ou não à poluição atmosférica a nível ambiental na fase pré-uterina e durante o período de lactação. Grupos experimentais: F (filtrado), NFF (não filtrado/filtrado), FNF (filtrado/não filtrado), NF (não filtrado).

Gráfico 8: Representação gráfica do número de células (neurônios e neuroglia) do hipocampo cerebral de ratos adultos expostos ou não à poluição atmosférica a nível ambiental na fase pré-uterina e durante o período de lactação. Grupos experimentais: F (filtrado), NFF (não filtrado/filtrado), FNF (filtrado/não filtrado), NF (não filtrado). 
Gráfico 9: Representação gráfica do número de células (neurônios e neuroglia) do estriado cerebral de ratos adultos expostos ou não à poluição atmosférica a nível ambiental na fase pré-uterina e durante o período de lactação. Grupos experimentais: $F$ (filtrado), NFF (não filtrado/filtrado), FNF (filtrado/não filtrado), NF (não filtrado). 


\section{Lista de tabelas}

Tabela 1: Fórmulas utilizadas no cálculo dos índices do Teste do Reconhecimento Espontâneo de Objetos.

Tabela 2: Avaliação do desenvolvimento de ratos machos expostos ou não à poluição atmosférica a nível ambiental durante a vida intra-uterina e o período de lactação.

Tabela 3: Determinação das concentrações de elementos traço tóxicos no sangue total de ratos adultos expostos ou não à poluição atmosférica ambiental durante a fase intra-uterina e o período de lactação.

Tabela 4: Determinação das concentrações de elementos traço essenciais no sangue total de ratos adultos expostos ou não à poluição atmosférica ambiental durante a fase intra-uterina e o período de lactação.

Tabela 5: Valores dos volumes das estruturas encefálicas (córtex, hipocampo e estriado) dos ratos adultos expostos ou não à poluição atmosférica a nível ambiental durante a fase pré-natal e o período de lactação.

Tabela 6: Comparação entre as concentrações médias de cada elemento traço obtidas através da técnica de fluorescência de raios $X$ (FRX) para as amostras coletadas de $\mathrm{MP}_{2.5}$ em filtros de policarbonato provenientes das cidades de Porto Alegre (POA) e São Paulo (SP). 


\section{Resumo}

Zanchi, ACT. Estudo das alterações no desenvolvimento, comportamento $e$ bioquímica cerebral de ratos machos expostos à poluição atmosférica ambiental na fase intra-uterina [Tese]. São Paulo: Faculdade de Medicina, Universidade de São Paulo; 2010. 218 páginas.

Estudos experimentais feitos em nosso laboratório comprovaram que a inalação de material particulado proveniente da queima de combustíveis fósseis utilizados em siderurgia pelos ratos adultos diminuiu a atividade motora dos animais no campo aberto. Além disso, provamos que os ratos habituaram ao ambiente desse teste, o que significa que a inalação desse tipo de material não provocou variação em termos de aprendizado simples. Uma das causas da alteração no comportamento em relação à motricidade seria o estresse oxidativo causado pelo material particulado no estriado e cerebelo desses animais. Entretanto, em nossa cidade não existem estudos que demonstrem a estreita associação entre inalação de poluentes, estresse oxidativo e alterações comportamentais. Baseados nos nossos trabalhos anteriores e na literatura, nosso objetivo foi investigar se a poluição atmosférica a nível ambiental durante as fases pré e pós-natal alteraria a memória discriminativa de curta-duração e a memória espacial. Além disso, avaliamos o papel do estresse oxidativo como o mecanismo propulsor dessas mudanças de comportamento. Para tal, ratas prenhas foram expostas ao ar filtrado e ao ar não filtrado durante os 21 dias de gestação. Ao final do período de amamentação, os machos foram separados e subdividos em 4 grupos experimentais ( $n=24):$ 1) Filtrado: nasceu e viveu em ambiente cujo ar era filtrado, 2) NFF: nasceu em ambiente cujo ar era não filtrado e viveu a partir do $21^{\circ}$ dia do pós-natal no ambiente com ar filtrado, 3) FNF: nasceu sob ar filtrado e viveu a partir do $21^{\circ}$ dia do pós-natal sob ar não filtrado, 4)NF: nasceu e viveu em ambiente cujo ar era não filtrado. Os animais ficaram expostos a poluição por 150 dias. Os animais foram divididos em 3 lotes: lote 1: $n=6$ animais por grupo; após anestesia profunda, os animais foram perfundidos com soro fisiológico seguido de paraformaldeído $4 \%$, o encéfalo foi retirado e dissecado em córtex, hipocampo e estriado para análises histológicas por técnicas estereológicas; lote 2: $n=12$ ratos por grupo; aplicação dos testes comportamentais; um dia após os testes, esses animais foram eutanasiados por decapitação, o encéfalo retirado e dissecado da mesma forma citada anteriormente para análise de estresse oxidativo; lote 3: $n=6$ animais por grupo; os animais foram decapitados e o sangue troncular coletado para análises de elementos traço tóxicos e essenciais no sangue total. O córtex apresentou lipoperoxidação no grupo NF quando comparado aos outros grupos, assim como uma alta concentração de $\mathrm{Cd}$ no sangue. O grupo NFF apresentou uma maior concentração de $\mathrm{Cu}$, Se e $\mathrm{Zn}$ no sangue em relação aos demais. Em relação à memória discriminativa de curta-duração, houve uma diminuição no grupo NF em relação aos demais grupos. No hipocampo e estriado, foi observado aumento da lipoperoxidação nos grupos FNF e NF, respectivamente, quando comparado aos outros grupos. Quanto à memória espacial, não houve diferença estatisticamente 
significativa entre os grupos. Primeiramente, como pudemos observar, o cada estrutura encefálica apresenta uma resposta ao estresse oxidativo. O córtex do grupo NF apresentou aumento de lipoperoxidação. Como se sabe, o Cd é feto tóxico e passa via transplacentária adsorvido ao material particulado inalado pela mãe. No caso do grupo NF, o $\mathrm{Cd}$ possivelmente deslocou o $\mathrm{Zn}$ do sítio ativo da enzima CuZn superóxido dismutase formando forma inativada da mesma. O Cd, também, forma conjugado com duas moléculas de glutationa reduzida a fim de ser excretado pela bile. Isso reduz a sua capacidade antioxidante. Esse elemento traço desloca o Fe e o $\mathrm{Cu}$ dos sítios ativos das suas proteínas de armazenamento, a ferritina e a ceruplasmina, respectivamente. Esses dois elementos ficam livres para catalisar a reação de Fenton cujo produto é o radical hidroxil, extremamente tóxico para o organismo. O grupo NF apresentou uma diminuição na capacidade de discriminar dois objetos diferentes. Provavelmente, o $\mathrm{Cd}$ agiu de forma indireta diminuindo a capacidade antioxidante da CuZn superóxido dismutase e da glutationa, além de liberar $\mathrm{Fe}$ e $\mathrm{Cu}$ e aumentar a produção de radical hidroxil. $\mathrm{O}$ aumento da lipoperoxidação causado pelo $\mathrm{Cd}$ pode ser o mecanismo responsável pela perda desse tipo de memória. Entretanto, o grupo NFF, cuja exposição à poluição foi na fase pré-natal, não apresentou aumento na lipoperoxidação. Possivelmente, a alta concentração dos elementos traço essenciais, $\mathrm{Cu}, \mathrm{Zn}$ e Se aumentou a atividade das enzimas CuZn superóxidodismutase e glutationa peroxidase, respectivamente, o que evitou danos oxidativos durante o período intra-uterino. O grupo FNF apresentou aumento de lipoperoxidação no hipocampo, mas não houve diferença na memória espacial testada com o labirinto de Morris modificado. Portanto, considerando todos os achados, concluímos que, possivelmente, o aumento da lipoperoxidação causado indiretamente pelo $\mathrm{Cd}$ pode ser um dos mecanismos responsáveis pela perda da capacidade da memória discriminativa de curtaduração. Além disso, os elementos traço essenciais exercem uma proteção via aumento das defesas antioxidantes dos animais que nasceram em ambiente poluído e, após 21 dias de vida, foram transferidos para o ambiente com o ar filtrado, o que demonstra, provavelmente, a existência de mecanismos antioxidantes de adaptação em ambientes inóspitos como forma de proteção contra o agente agressor durante o desenvolvimento do embrião. 


\begin{abstract}
Zanchi, ACT. Study of the alterations in the development, behavior and cerebral biochemistry of male rats exposed to the environmental atmospheric pollution in the intra-uterine phase [Thesis]. São Paulo: University of Medicine, University of São Paulo; 2010. 218 páginas.
\end{abstract}

Experimental studies done at our laboratory demonstrated that the inhalation of residual oil fly ash by the adult rats decreased motor activity of the animals in the open-field test. Additionaly, we showed that rats which inhalated residual oil fly ash preserved its habituation capacity. In this study, oxidative stress in striatum and cerebellum might be the cause of motor activity alterations. However, there were any studies about air pollution and behavioral alterations in Porto Alegre. Based on our previous works and in the literature, our objective was to investigate if the exposure to air pollution during intrauterine and lactation periods would damage the short term discriminative and spatial memories and if the mechanisms would be dependent of oxidants. For such, female pregnant rats were exposed to the filtered air and to the non filtered air during the 21 days of gestation. At the end of the breast-feeding period, the males were separate and divided in 4 experimental groups ( $n=24)$ : 1) Filtered $(F)$ : - pre and post-natal exposure until adulthood in filtered air; 2) non filtered/filtered air (NFF): pre-natal period in non-filtered air until PND21 and post-natal in filtered air until adulthood; 3) filtered air/non-filtered air (FNF): pre-natal period in filtered air until PND 21 and post-natal period in nonfiltered air until adulthood; 4) non filtered air (NF): pre and post-natal periods in non-filtered air.The animals were exposed the pollution for 150 days. The animals were divided in 3 lots: lot 1: $n=6$ animals per group; after anesthesia, the animals were perfused with saline solution following by paraformaldehyde $4 \%$, the brain was removed and dissected in cortex, hippocampus and striatum for histological analyses by stereological techniques; lot 2: $n=12$ rats per group; submitted to behavioral tests; one day after the tests, those animals were euthanized by decapitation, the brain was removed and dissected in the same way mentioned previously for oxidative stress analysis; lot 3: 6 animals per group; the animals were decapitated and the troncular blood was collected to analyze the toxic and the essential trace elements. The cortex presented lipoperoxidation in NF group when compared to other groups, as well as a high concentration of $\mathrm{Cd}$ in the blood. The group NFF presented higher blood concentration of $\mathrm{Cu}$, Se and $\mathrm{Zn}$ when compared to other groups. There was a decrease in the discriminative capacity in the group NF when compared to other groups. In the hippocampus and striatum, increases of lipidperoxidation were observed in the groups FNF and NF, respectively, when compared to other groups. Spatial memory of all groups was preserved. We observed the each brain structure reacts in a different way to oxidative stress. The NF cortex group presented an increased of lipidperoxidation. In this group, there was higher $\mathrm{Cd}$ blood concentration, which passes through placenta and it is fetotoxic. It might be possible that $\mathrm{Cd}$ dislocated $\mathrm{Zn}$ of the active site of CuZn 
superóxido dismutase resulting in inactive forms of this enzyme. The $\mathrm{Cd}$ also depletes reduced glutathione. Moreover, $\mathrm{Cd}$ may dislocate the $\mathrm{Fe}$ and $\mathrm{Cu}$ from its storage proteins to react with oxygen peroxide increasing the hydroxyl radical production by Fenton reaction. The group NF presented a decrease in the capacity to discriminate two different objects. Cd may act in an indirect way reducing the antioxidant capacity of CuZn superxidodismutase and of the glutathione and increasing the hydroxyl radical production. Lipoperoxidation in NF cortex caused by the $\mathrm{Cd}$ may be one of the mechanisms which explain the loss of discriminative capacity. However, the group NFF, whose air pollution exposure was in the prenatal period, did not present increase of lipidperoxidation. The higher concentrations of essential trace elements ( $\mathrm{Cu}$, Se and $\mathrm{Zn}$ ) may protect this group against oxidative stress. These elements are cofactor of antioxidants enzymes, superoxidodismutase and glutathione peroxidase and increased its activities during the intra-uterine exposure to air pollution. The group FNF presented lipidperoxidation increase in the hippocampus, but there was no difference in the spatial memory tested with Morris' maze. Therefore, considering our data, we suggested that the increase of lipidperoxidation caused indirectly by $\mathrm{Cd}$, which was adsorbed in particulate matter surface, may be one of the mechanisms which explain the loss of short-term discriminative memory. 


\section{INTRODUÇÃO}

\subsection{Aspectos gerais sobre a poluição atmosférica}

Poluente, segundo a Resolução 03/90 de 28/06/1990 do Conselho Nacional do Meio Ambiente, é qualquer substância presente no ar, que, pela sua concentração, possa torná-lo impróprio, nocivo ou prejudicial à saúde, fauna e flora (Brasil. Conselho Nacional do Meio Ambiente, 1990).

As fontes emissoras de poluentes são classificadas em naturais e antropogênicas. Atividade vulcânica, queima de biomassa, decomposição de material orgânico, incêndios e queimadas são exemplos de fontes naturais. As antropogênicas advêm de atividades humanas e podem ser fixas como, por exemplo, as siderúrgicas e termelétricas, ou móveis, no caso, os veículos automotores (Oga, 2003). Além disso, os poluentes são classificados como primários, quando emitidos diretamente da fonte de emissão, e secundários quando resultantes de reações químicas entre os primários e substâncias presentes na atmosfera (Oga, 2003). Alguns dos parâmetros que influenciam na dispersão e concentração de poluentes dependem das características das fontes emissoras, tais como temperatura e velocidade de saída do gás, altura da chaminé e de fatores climáticos como a precipitação pluviométrica, luz solar, umidade relativa, temperatura do ar, velocidade e direção dos ventos, presença ou não de nuvens e neblina, pressão atmosférica, inversões térmicas, etc. (Oga, 2003). Dentre os 
poluentes mais comuns encontram-se o ozônio $\left(\mathrm{O}_{3}\right)$, o material particulado (MP), o monóxido de carbono (CO), os óxidos de nitrogênio (NOx), o dióxido de enxofre $\left(\mathrm{SO}_{2}\right)$ e o chumbo (Pb) (United States Environmental Protection Agency, 2009).

Especificamente, o material particulado (MP) é o conjunto de poluentes constituído por poeiras, fumaça e todo o tipo de material sólido e líquido suspenso na atmosfera variando em proporção e composição diariamente. Individualmente, estas partículas são invisíveis, mas, coletivamente, podem aparecer como nuvens ou "massa" escura suspensa no ar por longo tempo, sendo movimentada pelos ventos. O tamanho das partículas é variado e as mesmas são classificadas conforme o diâmetro aerodinâmico em grossas $\left(\mathrm{MP}_{10}\right)$, partículas com diâmetro entre 10 e 2,5 micra; finas $\left(\mathrm{MP}_{2,5}\right)$, diâmetro entre 2,5 e 0,1 micra; e, ultrafinas $\left(\mathrm{MP}_{0,1}\right)$, diâmetro menor do que 0,1 micra. A toxicidade do $\mathrm{MP}_{2,5}$ e $\mathrm{MP}_{0,1}$ está relacionada à massa, ao tamanho e à composição química, a qual caracteriza-se pela presença de metais de transição e compostos orgânicos adsorvidos na sua superfície, além de sulfatos e nitratos formados a partir da oxidação do dióxido de enxofre e dos óxidos de nitrogênio, respectivamente (Bérubé e cols., 2006; United States Environmental Protection Agency, 2009; Kaiser, 2000; Schwela, 2000). Martins e cols. (2009) confirmaram que as partículas ultrafinas, embora a qualidade do ar durante o período noturno seja melhor e a sua massa total, menor que a média anual preconizada pela Organização Mundial da Saúde $\left(10 \mu \mathrm{g} / \mathrm{m}^{3}\right)$ (2006), são mais tóxicas após a sua deposição nos pulmões. 
A principal fonte de emissão do MP são os veículos automotores. No Rio Grande do Sul, a frota, segundo levantamento realizado pelo Departamento de Trânsito do Estado do Rio Grande do Sul em 2001, era de três milhões e cem mil veículos, dos quais 40 e $20 \%$ pertenciam à Região Metropolitana de Porto Alegre e à cidade de Porto Alegre, respectivamente. Entre os anos de 1997 e 2002, o número de veículos apresentou um crescimento médio de 5\% ao ano. Estimativas feitas com base nesta taxa preveem em 2010 uma frota de cinco milhões (Fundação Estadual de Proteção Ambiental - Rio Grande do Sul, 2001.

No cenário nacional, realizou-se o projeto de avaliação ambiental através da coleta e da determinação da composição química do MP em 6 capitais brasileiras durante os anos de 2007 e 2008. Conforme o relatório final do referido estudo, Porto Alegre (figura 1) está em segundo lugar no Brasil em termos de concentração média anual de $\mathrm{MP}_{2,5}\left(22,25 \mu \mathrm{g} / \mathrm{m}^{3}\right.$ de ar), coletada no período do inverno, mensurada em 2007 (Laboratório de Poluição Atmosférica Experimental, Laboratório de Análise de Processos Atmosféricos, 2009). 


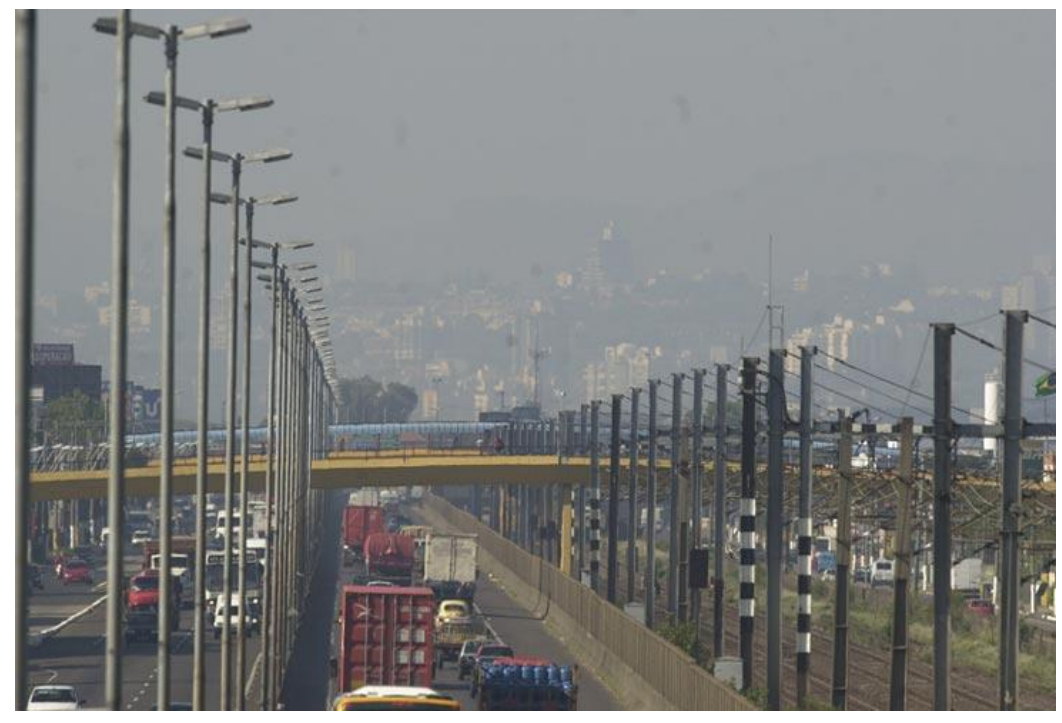

Figura 1: Vista da Avenida Castelo Branco em Porto Alegre (foto gentilmente cedida por Leandro da Silva Cardoso).

\subsection{Poluição do ar e efeitos sobre a saúde}

A poluição do ar é um problema de saúde pública. Dentre os sistemas mais estudados em relação à exposição aguda e crônica aos poluentes, encontram-se o cardiorrespiratório, o reprodutivo e o sistema nervoso central (SNC) (Organização Mundial da Saúde, 2006).

\subsubsection{Efeitos sobre o sistema cardiorrespiratório}

Estudos epidemiológicos demonstraram a existência de uma forte associação entre a alta concentração de poluentes na atmosfera e a morbimortalidade de doenças cardíacas e respiratórias em crianças e idosos (Saldiva $e$ cols., 1994; Saldiva e cols. 1995). Lin e cols. (2004) comprovaram que dois 
poluentes, $\mathrm{MP}_{10}$ e dióxido de enxofre $\left(\mathrm{SO}_{2}\right)$, estavam associados ao número de mortes diárias de recém nascidos. Entre os anos de 1993 e 1997, em São Paulo, Freitas e cols. (2004) mostraram que cada incremento de $10 \mu \mathrm{g} / \mathrm{m}^{3}$ na concentração de $\mathrm{MP}_{10}$ elevou em 1,1\% o número de mortes de idosos e causou um acréscimo de 1,3\% nos atendimentos de emergência por doenças respiratórias pré-existentes. Este estudo mostrou, também, o aumento no número de admissões hospitalares por doenças respiratórias em menores de 15 anos devido à alta concentração de poluentes, $\mathrm{MP}_{10}$, monóxido de carbono (CO) e ozônio $\left(\mathrm{O}_{3}\right)$ (Freitas e cols., 2004). Além disso, Lin e cols. (2003) demonstraram a correlação entre o aumento na quantidade de $\mathrm{CO}$ no ar e o incremento em $6,4 \%$ dos atendimentos por anginas e infarto agudo do miocárdio em emergência hospitalar. Miraglia e Saldiva (2005) demonstraram redução na expectativa de vida das pessoas idosas em 4 anos (considerando as doenças respiratórias) e 10 anos (considerando as doenças cardíacas). Em relação às crianças, o decréscimo foi de 19 anos (doenças respiratórias em crianças). A valoração da exposição à poluição do ar tornou-se um tópico relevante. O tempo, durante o qual as pessoas ficaram incapacitadas de exercer as atividades laborais e diárias, em razão das doenças acima, foi de $\mathbf{2 8 . 2 1 2}$ anos, anualmente. E o custo indireto na saúde pública devido à exposição aos poluentes resultou em U\$ 3.222.676, valor estimado apenas em relação às crianças e aos idosos (Miraglia e Saldiva, 2005).

Entre os mecanismos sugeridos para o aumento da morbi-mortalidade por doenças cardiorrespiratórias estão os efeitos tóxicos diretos causados pelas próprias partículas nos órgãos alvos (liberação de espécies ativas de oxigênio - EAO) 
e indiretos, causados pela liberação de mediadores pró-inflamatórios por macrófagos estimulados pelo MP e pela estimulação neural, após a deposição das partículas nos pulmões (Gurgueira e cols., 2002). Esta resposta inflamatória, induzida pela ação das substâncias oxidantes acarreta aumento na acidez, na viscosidade e na consistência do muco produzido pelas vias aéreas levando, por conseguinte, à diminuição da resposta e/ou eficácia do sistema muco ciliar (Cançado e cols., 2006). A exposição ao MP promove, também, resposta inflamatória sistêmica que inclui estimulação da medula óssea e progressão da aterosclerose. Estudos experimentais feitos em animais expostos à poluição atmosférica revelaram que a vulnerabilidade e o rompimento da placa aterosclerótica podem estar relacionadas à exposição ao MP e ao excesso de mortes por doenças cardiovasculares (Lewtas, 2007). Corroborando esses achados, Ferreira Rivero e cols. (2005) mostraram que ratos tratados com $\mathrm{MP}_{2,5}$, através da instilação intratraqueal, apresentaram incremento significativo no número total de reticulócitos, ocasionando aumento na viscosidade do sangue e piora da doença cardíaca congestiva crônica e cardíaca isquêmica. 


\subsubsection{Efeitos relacionados à exposição aos poluentes nas fases pré e pós-natal}

O período gestacional é crítico, pois a exposição materna aos poluentes pode afetar o desenvolvimento fetal tanto em seres humanos como em animais.

Inúmeros estudos em animais e humanos têm demonstrado a relação entre a exposição materna aos poluentes, a mortalidade neonatal e os defeitos congênitos (Lewtas, 2007; Damaceno-Rodrigues e cols., 2009; Veras e cols., 2008; Veras e cols., 2009). Veras e cols. (2008) mostraram aumento na difusão transplacentária de substâncias em camundongos fêmea expostos aos níveis de poluição urbana durante o período pré-gestacional e gestacional. Em 2009, os mesmos pesquisadores mostraram que as fêmeas que inalaram MP a nível ambiental apresentaram uma redução no número de ciclos, de folículos e na implantação dos embriões, bem como o baixo peso dos filhotes. Reliene e cols. (2005) constataram aumento na frequência de mutações no ADN (ácido desóxiribonucléico) dos filhotes cujas mães foram expostas ao MP.

Em estudos conduzidos em mulheres, Lacasãna e cols. (2005) revelaram a associação entre o incremento de $10 \mu \mathrm{g} / \mathrm{m}^{3}$ na concentração de $\mathrm{MP}_{10}$ e $22 \%$ de acréscimo no número de óbitos de recém-nascidos por doenças respiratórias. A exposição materna ao $\mathrm{O}_{3}$ no segundo e ao $\mathrm{CO}$ no terceiro mês de gravidez acarretou baixo peso dos bebês (Glinianaia e cols., 2004; Mannes, 2005; Maisonet e cols., 2004; Salam e cols., 2005). Do mesmo modo, as grávidas que inalaram dióxido de 
nitrogênio $\left(\mathrm{NO}_{2}\right)$, durante o período gestacional, apresentaram um risco $25 \%$ maior de parto prematuro (Maroziene e Grazuleviciene, 2002). O mecanismo sugerido para esclarecer a associação entre o $\mathrm{CO}$ e o baixo peso do neonato seria a competição entre este gás com o oxigênio $\left(\mathrm{O}_{2}\right)$, pelos sítios de ligação da hemoglobina, o que reduziria o transporte de $\mathrm{O}_{2}$ para os tecidos e prejudicaria o desenvolvimento fetal. Quanto à associação entre $\circ \mathrm{O}_{3}$ e a diminuição no peso do bebê ao nascer, estudos animais sugeriram que este efeito seria modulado pelo processo inflamatório materno. A prematuridade poderia ser explicada através da oxidação dos componentes teciduais (proteínas e lipídeos) pelo $\mathrm{NO}_{2}$ e da diminuição da proteção antioxidante do feto e da mãe. Estudos experimentais demonstraram que a inalação de $\mathrm{NO}_{2}$ durante o período de gestação não só induziu à oxidação dos lipídeos, os quais compõem a placenta, como causou elevada letalidade no período da pós-implantação do embrião (Tabakova e cols., 1997). Gilboa e cols. (2005) mostraram a existência de uma associação positiva entre a exposição ao CO e a tetralogia de Fallot (razão de chance: 2,04); entre o $\mathrm{MP}_{10}$ e defeitos no septo atrial (razão de chance: 2,27) e entre $\circ \mathrm{SO}_{2}$ e defeitos no septo ventricular (razão de chance: 2,16). Em estudo de Ritz e cols. (2002), o $\mathrm{CO}$ e $\mathrm{O}_{3}$ inalados durante o segundo mês de gestação, período crítico para o desenvolvimento do coração, causaram má formação congênita cardíaca.

Considerando os estudos apresentados, cabe ressaltar que são pouco conhecidos os mecanismos envolvidos nos danos ocasionados pela exposição à poluição do ar nas fases pré e pós-natal. Assim, há a necessidade de aprofundarmos 
os nossos conhecimentos para que possamos determinar os efeitos da inalação de poluentes durante a gestação em longo prazo.

\subsubsection{Efeitos no sistema nervoso central (SNC)}

Os poluentes do ar causam efeitos adversos no encéfalo através de vários mecanismos. A inflamação pulmonar persistente em cães e seres humanos devido à deposição das partículas finas e ultrafinas nos alvéolos pulmonares e a degeneração dos epitélios nasal e do trato respiratório acarretam a liberação de citocinas, como interleucinas 6 (IL-6), $1 \beta$ (IL-1 $\beta$ ) e fator de necrose tumoral $\alpha$ (TNF $\alpha)$ na circulação sistêmica. Estes mediadores inflamatórios ativam os receptores do endotélio vascular da barreira hematoencefálica (BHE) tornando-a mais permeável (CalderónGarcidueñas e cols., 2008a; Sunyer, 2008). Além disso, estas substâncias estimulam a medula a produzir macrófagos que, após ultrapassarem a BHE, se diferenciam em microglia. Estas células inflamatórias, por sua vez, ativam a liberação de óxido nítrico, proteases, derivados do ácido araquidônico e proteína precursora amilóide promovendo neuroinflamação (Block e Calderón-Garcidueñas, 2009; CalderónGarcidueñas e cols., 2008a; Calderón-Garcidueñas e cols., 2008b; CalderónGarcidueñas e cols., 2002; Calderón-Garcidueñas e cols., 2001b). Esta associação entre a exposição à poluição do ar urbano e inflamação no SNC foi confirmada a partir do estudo de coorte feito em adultos. No córtex pré-frontal e hipocampo destes indivíduos a expressão do ARNm (ácido ribonucléico mensageiro) para a 
transcrição da enzima ciclooxigenase 2 (COX2) estava elevada (CalderónGarcidueñas e cols., 2004). Além disso, foi observado aumento na expressão dos ARNm para IL-1 $\beta$ e COX2 no bulbo olfatório e córtex pré-frontal de crianças, adolescentes e adultos jovens (Calderón-Garcidueñas e cols., 2004). Estes trabalhos mostraram, também, que o MP e as substâncias adsorvidas na sua superfície como lipopolissacarídeos, metais derivados da combustão de diesel e gasolina - vanádio (V), níquel (Ni) - e hidrocarbonetos aromáticos policíclicos (HAP) foram captadas pelas terminações nervosas sensoriais do epitélio da cavidade nasal e, em seguida, através da translocação axonal, via bulbo olfatório, atingiram estruturas do SNC (figura 2) (Calderón-Garcidueñas e cols. 2001b; Calderón-Garcidueñas e cols. 2002; Calderón-Garcidueñas e cols., 2003a; Calderón-Garcidueñas e cols., 2003b, Calderón-Garcidueñas e cols. 2004; Calderón-Garcidueñas e cols. 2007; Oberdörster e cols., 2005a; Oberdörster e cols., 2005b; Oberdörster e Utell, 2002; Peters e cols., 2006;).

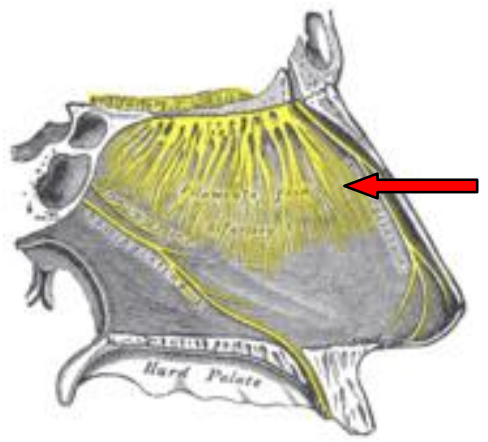

Figura 2: Representação esquemática das terminações nervosas sensoriais do epitélio nasal (seta vermelha) (Fonte: Wikipedia http://pt.wikipedia.org) 
Estudos de Calderón-Garcidueñas e cols., (2003b) demonstraram, ainda, que a exposição de cães a poluentes na cidade do México, provocou, além da inflamação cerebral, dano oxidativo e mutações no ADN, acúmulo do peptídeo beta amilóide $(A \beta 42)$ - fragmento hidrofóbico formado por 42 aminoácidos da proteína beta amilóide - nos neurônios e astrócitos, bem como sua deposição em placas no córtex frontal. Esse agregado de peptídeo beta amilóide $(A \beta 42)$ é característica patogênica do encéfalo de pacientes portadores do Mal de Alzheimer.

Em resumo, o MP penetra no SNC através de várias vias. Logo, as partículas podem atingir áreas mais profundas do encéfalo e provocar danos irreparáveis em estruturas importantes como o córtex pré-frontal, frontal e hipocampo.

\subsubsection{Exposição a substâncias neurotóxicas e processos cognitivos}

Conforme mencionado anteriormente, os mecanismos fisiopatológicos envolvidos nos danos sobre o sistema cardiorrespiratório induzidos pela exposição à poluição do ar são muito conhecidos. Existe uma lacuna a ser preenchida em termos de estudos que relacionem exposição aos poluentes e alterações no SNC.

A exposição a substâncias neurotóxicas nas fases pré-natal e pós-natal é motivo de preocupação, pois o feto e as crianças são mais sensíveis aos poluentes atmosféricos. Na fase gestacional, estes podem afetar o desenvolvimento do SNC e se manifestar tardiamente como distúrbios cognitivos e problemas emocionais 
durante a vida (Segalowitz, 2008). Perera e cols. (2006) mostraram que a exposição de mulheres, durante a fase gestacional, aos hidrocarbonetos aromáticos policíclicos (HAP) foi associada ao baixo desenvolvimento mental de crianças com 3 anos de idade na fase pré-escolar. Em outro estudo feito na China, Perera e cols. (2008) mostraram a associação entre aumento de mutações no ADN causadas pela inalação de HPA e redução no quociente de desenvolvimento da área motora em crianças com 2 anos de idade. O mesmo grupo demonstrou a existência de relação entre diminuição do quociente de inteligência em crianças de 5 anos e exposição na fase pré-natal aos HPA (Perera e cols., 2009). Além disso, pesquisa feita na Coréia do Sul, em 2009, revelou que a exposição na fase gestacional ao chumbo (Pb), mesmo em concentrações baixas, estava associada aos sintomas de distúrbio do déficit de atenção e hiperatividade (DDAH) (Ha e cols., 2009). Nesta mesma linha, Braun e cols. (2006) verificaram que tanto o $\mathrm{Pb}$ quanto a fumaça do cigarro eram fatores de risco para o DDAH. Do mesmo modo, Calderón-Garcidueñas e cols. (2008b) conseguiram demonstrar a relação entre o processo neuroinflamatório causado pela inalação de MP por crianças e adolescentes, com idades entre 7 e 17 anos, e diminuição no tamanho do córtex pré-frontal - estrutura relacionada ao aprendizado. Suglia e cols. (2008) corroboraram estes achados quando revelaram a relação entre inalação de partículas de carbono, resultantes da frota veicular, e declínio das funções cognitivas determinadas através de testes de inteligência verbal, não verbal e memória.

Já em investigações feitas em camundongos recém-nascidos de fêmeas expostas às partículas resultantes da queima do óleo diesel, não houve diferença no 
aprendizado referente à localização espacial conforme descrito por Hougaard e cols. (2008). Entretanto, Zanchi e cols. (2008) demonstraram que ratos adultos expostos ao ROFA, através da instilação intranasal, apresentaram aumento de lipoperoxidação no estriado, bem como redução da atividade motora no campo aberto. Em trabalho complementar, o mesmo grupo de pesquisadores observou que não havia prejuízo na capacidade de habituação destes animais quando expostos a situações seqüenciais a um mesmo ambiente (Zanchi e cols., 2010). 


\subsection{Desenvolvimento do SNC}

O primeiro tecido neural aparece ao final da primeira semana de desenvolvimento embrionário, quando o disco é composto de ectoderma, mesoderma e endoderma. Uma parte especializada do ectoderma, o neuroectoderma, origina o encéfalo, a medula espinhal e o sistema nervoso periférico (figura 3).

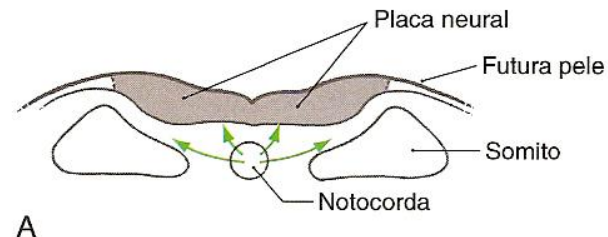

A

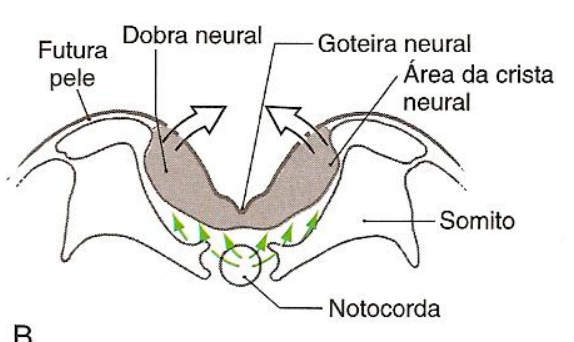

B

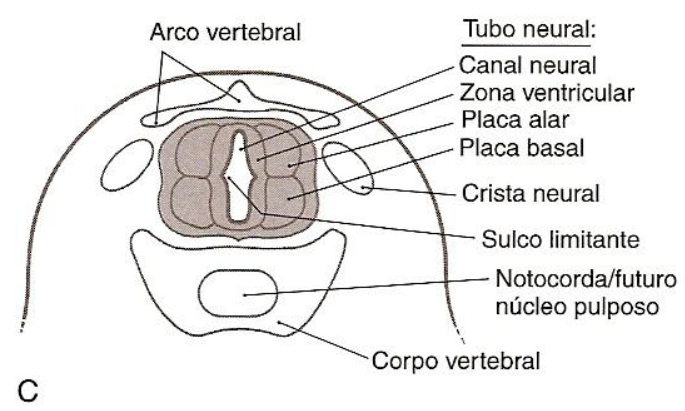

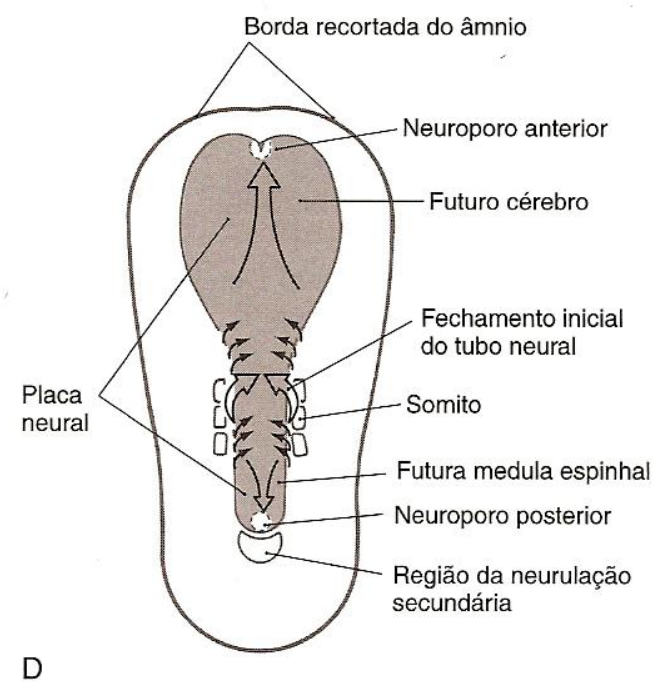

$\mathrm{D}$

Figura 3: Representação esquemática do desenvolvimento inicial do sistema nervoso. Cortes transversais $(A-C)$ mostrando a transição da placa neural $(A)$ para o tubo neural (C). Uma vista dorsal (D) da placa neural mostra o ponto de fechamento inicial e a direção do fechamento (pequenas setas) em direção aos neuroporos anterior e posterior. As setas verdes (A, B) representam a indução da formação do tubo neural (Evans e Hutchins, 2006). 
A notocorda se origina do mesoderma axial em cerca de 16 dias e está completamente formada no início da quarta semana. Ela define o eixo longitudinal do embrião, determina a orientação da coluna vertebral e persiste como núcleo pulposo dos discos intervertebrais. Uma importante função da mesma é a indução, ou seja, dirigir o ectoderma adjacente para formar a placa neural (figura 3, A-B). A produção das moléculas de adesão celular na notocorda está associada a este processo. Estas se difundem da mesma para dentro da placa neural e unem as células neuroepiteliais primitivas em uma unidade compacta (Evans e Hutchins, 2006).

Dentro do neuroectoderma, algumas células neuroepiteliais se alongam e se tornam fusiformes. Este alongamento celular, induzido também pela notocorda, forma a placa neural e é finalizado ao final da terceira semana de gestação (figura 3, A). A placa neural origina a maior parte do sistema nervoso (Evans e Hutchins, 2006).

Conforme descrito anteriormente, o SNC se desenvolve a partir de uma estrutura côncava chamada tubo neural, a qual é produzida pela neurulação. Existem dois processos de neurulação. A maior parte do tubo neural se forma a partir da placa neural, por um processo de envolvimento chamado neurulação primária. Esta parte do tubo neural originará o encéfalo e a medula espinhal até os níveis lombares. A porção mais caudal do tubo neural, a qual dará origem ao nível sacral e coccígeo da medula, é formada por um processo chamado neurulação secundária. Aproximadamente no $18^{\circ}$ dia após a fertilização, a placa neural começa 
a se espessar em suas margens laterais (figura 3, B) (Lent, 2004; Evans e Hutchins, 2006). Este espessamento eleva as bordas da placa neural para formar as dobras neurais. Em torno de 20 dias, as dobras neurais contatam uma à outra para formar o tubo neural. Esta fusão ocorre, inicialmente, na linha média dorsal, que se transforma nos níveis cervicais da medula espinhal e prossegue, como um zíper, na direção caudal e rostral (figura 3, C-D). Durante o processo, o lúmen do tubo neural, chamado de canal neural, é aberto para a cavidade amniótica tanto rostral quanto caudalmente (figura 3, D). A abertura rostral, o neuroporo anterior, se fecha em cerca de 24 dias, e a abertura caudal, o neuroporo posterior, 2 dias mais tarde (Lent, 2004; Evans e Hutchins, 2006).

A neurulação é provocada por alterações morfológicas nos neuroblastos, os futuros neurônios imaturos em divisão na zona ventricular. Como previamente mencionado, estas células são alongadas e orientadas em ângulos retos para a superfície dorsal da placa neural, que será a parede interna do canal neural. Microfilamentos em cada célula formam um feixe circular paralelo à futura superfície luminal, enquanto os microtúbulos se estendem ao longo do comprimento da célula. A contração do feixe circular de microfilamentos faz com que os microtúbulos se alarguem em ângulo, como os raios de um leque. Isto forma uma célula cônica alongada, com o seu ápice na goteira neural e sua base na borda da dobra neural (Lent, 2004; Evans e Hutchins, 2006).

As malformações congênitas associadas, com a neurulação defeituosa, são chamadas de defeitos disráficos. 0 processo de indução significa que o 
desenvolvimento apropriado de uma estrutura é dependente da formação das estruturas vizinhas. Há uma relação íntima do tecido neural com o osso circundante, as meninges, os músculos e a pele. Devido a esta relação, uma falha na neurulação quase sempre prejudica a constituição destas estruturas circundantes (Lent, 2004; Evans e Hutchins, 2006).

A organização do encéfalo determina o seu funcionamento. Os três parâmetros importantes na organização cerebral são: a densidade de neurônios, o padrão de ramificação dos axônios e dendritos e o padrão dos contatos sinápticos. Estas características começam a se desenvolver ao final do período de pico da migração neuronal, no sexto mês de gestação. Apesar de a densidade neuronal e dos padrões básicos do crescimento axonal e dendrítico serem determinados dentro de 2 a 3 anos após o nascimento, a remodelagem das conexões sinápticas continua ao longo da vida (Evans e Hutchins, 2006; Lent, 2004; Thompson, 2005).

A embriogênese produz de uma e meia a duas vezes mais neurônios em relação às células presentes no encéfalo maduro. Em 24 semanas de gestação, quase todos os neurônios já foram produzidos. Subsequente a isto há morte seletiva de células neuronais (Evans e Hutchins, 2006; Lent, 2004; Thompson, 2005). A morte celular geneticamente programada, apoptose, dos neurônios é uma característica do desenvolvimento celular em muitas áreas do cérebro. Ao contrário da necrose (morte celular como resultado de lesão), apoptose requer síntese protéica e, portanto, é um processo celular ativo. Alguns fatores de crescimento interrompem o processo normal de apoptose. Os fatores de crescimento do nervo, 
neurotrófico, e do fibroblasto são conhecidos como inibidores da morte celular. Este achado levou à idéia de que a administração de tais fatores de crescimento poderia bloquear a morte celular neuronal, que ocorre em certas doenças degenerativas (Evans e Hutchins, 2006; Lent, 2004; Thompson, 2005).

Após os neuroblastos completarem a sua divisão celular final e migrarem para a sua localização definitiva, eles começam a estender um único axônio com uma ou mais elaborações distais, conhecidas como cones de crescimento. Esta extensão, em forma de ponta de espada do axônio em crescimento, é capaz de se dirigir através dos campos de tecido nervoso ou mesenquimatosos em desenvolvimento para alcançar alvos distantes. A orientação dos cones de crescimento é influenciada por ambos os fatores trópicos (que guiam a célula em direção a um determinado alvo) e tróficos (que mantêm o metabolismo de uma célula ou seus processos). Enquanto um axônio cresce, este pode emitir ramificações, cada uma com o seu próprio cone de crescimento. Algumas ramificações podem terminar em sítios que não serão, em última instância, inervados pela célula. Por exemplo, as células do córtex motor, que emitem axônios para a medula espinhal, para inervar os neurônios motores, também emitem ramificações temporárias paras as estruturas do tronco encefálico e estas conexões ectópicas não são normalmente mantidas (Evans e Hutchins, 2006; Lent, 2004; Thompson, 2005).

Uma vez que o cone de crescimento axonal chega a seu sítio de terminação, - mesmo sofre alterações bioquímicas e morfológicas para se tornar uma 
terminação pré-sináptica. Similarmente, a área do neurônio alvo contatado pelo processo pré-sináptico começa a expressar o maquinário pós-sináptico característico, como os receptores de neurotransmissores e as moléculas de segundos mensageiros (Evans e Hutchins, 2006; Lent, 2004; Thompson, 2005).

Uma visão do desenvolvimento da sinapse é a de que há uma competição pelo espaço sináptico disponível nos neurônios alvo. Uma sinapse que se forma persistirá apenas se intercambiar as pistas certas com a célula alvo. Muitas sinapses que se formam são imediatamente perdidas e substituídas por outras que podem ser mais bem-sucedidas. Assim, somente um subconjunto do grande número de sinapses que se formam é retido ao final. Este é o conceito de estabilização sináptica, e ele requer (1) um sinal gerado pela célula pré-sináptica, possivelmente o neurotransmissor a ser utilizado na sinapse adulta; (2) um meio da célula póssináptica responder ao sinal pré-sináptico; e (3) um sinal retrógrado da célula póssináptica para a célula pré-sináptica, para indicar quais permanecerão na maturidade (Evans e Hutchins, 2006; Lent, 2004; Thompson, 2005).

Um importante processo relacionado à organização neuronal é a plasticidade. O encéfalo em formação não é tão vulnerável à lesão quanto o maduro. Os bebês que sofrem lesão cortical significativa, no período pré-natal ou no início do pós-natal, podem apresentar uma recuperação funcional surpreendente, terminando com pouco ou nenhum déficit óbvio. O mecanismo de plasticidade se relaciona com as alterações na morte neuronal e na simplificação axonal seletivas, e com a retenção das ramificações axonais e sinapses temporárias 
que, de outro modo, seriam perdidas, como discutidas anteriormente (Evans e Hutchins, 2006; Lent, 2004; Thompson, 2005).

O desenvolvimento sináptico ocorre em paralelo com a proliferação e migração celular. As espinhas dendríticas constituem o sítio de muitos contatos sinápticos, especialmente nos neurônios corticais. Nas diferentes partes do encéfalo, a frequência da formação da espinha varia, mas é normalmente máxima durante o sexto mês após o nascimento. Muitas crianças com retardo mental, incluindo aquelas com síndrome de Down, possuem menos ramificações axonais e dendríticas, em quantidade e complexidade, e menos espinhas dendríticas do que crianças normais. Em alguns pacientes, há perturbação da estrutura citoesquelética que sustenta a arquitetura dos processos axonais. O desenvolvimento axonal e sináptico são especialmente vulneráveis à hipóxia perinatal, desnutrição e às toxinas ambientais (Evans e Hutchins, 2006).

Os oligodendrócitos mielinizam os axônios dos neurônios no SNC. A mielinização começa em torno do sexto mês e atinge o pico entre o nascimento e o primeiro mês de vida, mas continua na idade adulta. Um retardo na mielinização pode resultar em atraso no desenvolvimento funcional. O melhor exemplo é uma cegueira cortical congênita, que se resolve durante o primeiro ano de vida (Evans e Hutchins, 2006). Existe uma hierarquia definida na maturação regional da formação de mielina. Os tratos motor e sensorial ao longo do sistema nervoso amadurecem cedo, enquanto os de associação completam o seu desenvolvimento relativamente mais tarde. Diversas doenças neurodegenerativas (leucodistrofias) afetam a 
formação da mielina. Muitos erros inatos do metabolismo de aminoácidos e ácidos orgânicos prejudicam a mielinização, notavelmente a fenilcetonúria. Finalmente, a nutrição inadequada pode, também, prejudicar o processo de mielinização (Evans e Hutchins, 2006). 


\subsection{Aspectos gerais sobre as memórias}

Memória é a codificação, a conservação e a evocação de informações."

(Izquierdo, 2002)

A codificação se refere ao processamento da nova informação a ser armazenada e envolve duas fases: aquisição e consolidação. A aquisição registra as informações em arquivos sensoriais e estágios de análise sensorial, enquanto a consolidação cria forte representação das mesmas através do tempo. 0 armazenamento, resultado da aquisição e da consolidação, cria e mantém um registro permanente. Finalmente, a evocação utiliza a informação armazenada para criar uma representação consciente ou executar um comportamento aprendido através da atividade motora (Gazzaniga e cols., 2006).

Didaticamente, existem dois tipos de memória: a não declarativa e a declarativa. A memória não declarativa se reflete no desempenho - no modo como fazemos algo. Este tipo de memória inclui várias habilidades motoras e sensoriais, hábitos, aprendizado emocional e formas elementares de aprendizado reflexo, tais como habituação, sensibilização e condicionamento clássico e operante (Izquierdo, 2002; Squire e Kandel, 2003; Thompson, 2005). Logo, a memória não declarativa ou implícita envolve tipicamente um conhecimento que é de natureza reflexa, mas que não exige reflexão. Quando alguém aprende a andar de bicicleta, no início há a necessidade de dispensar uma enorme atenção ao tentar controlar a roda dianteira com o guidom, além de estar atento também ao ato de empurrar os pedais, 
primeiro com o pé esquerdo e depois com o direito. No entanto, à medida que andar de bicicleta se tornou uma prática, a tarefa começou a ficar armazenada como memória não declarativa. O indivíduo continua a observar o caminho com atenção, mas agora dirige e pedala automaticamente - de forma reflexa, e não refletindo sobre isso (Izquierdo, 2002). O exemplo mais simples desse tipo de memória é a habituação, que é aprender a reconhecer e ignorar, considerando familiares estímulos sem importância, para que não sejam repetidos de forma monótona. Em termos de comportamento animal, o rato explorará menos o ambiente ao qual for exposto inúmeras vezes. Esta diminuição na exploração caracteriza a habituação (Squire e Kandel, 2003; Thompson, 2005).

A memória declarativa é a memória para eventos, fatos, palavras, faces, música - todos os fragmentos do conhecimento que fomos adquirindo durante uma vida de experiência e aprendizado. Este conhecimento pode ser declarado, isto é, trazido à mente de uma forma verbal ou como imagem mental. Este tipo de memória é, também, denominado explícita ou consciente. Ainda, a mesma se subdivide em memória episódica e semântica. A episódica é a autobiografia dos eventos da vida de alguém, bem como armazenamento de marcos espaciais e temporais que identificam o tempo e o lugar, em particular onde um evento ocorreu. Já a semântica é o conhecimento organizado do mundo (Izquierdo, 2002; Squire e Kandel, 2003; Thompson, 2005).

Em resumo, memória não declarativa remete ao aprendizado de procedimentos como andar de bicicleta e à habituação, as quais independem da 
reflexão antes de partir para a ação. Já a memória declarativa é o armazenamento de informações inerentes à autobiografia do indivíduo e ao conhecimento organizado do mundo.

\subsubsection{Estruturas cerebrais envolvidas na formação das memórias}

Tanto as memórias episódicas quanto as semânticas requerem para seu correto funcionamento, quer na aquisição, quer na formação ou na evocação uma boa memória de trabalho, um bom funcionamento do córtex pré-frontal. As principais estruturas nervosas responsáveis pelas memórias episódicas e semânticas são duas áreas intercomunicadas do lobo temporal: o hipocampo e o córtex entorrinal. Ambas trabalham associadas entre si e em comunicação com outras partes do córtex, como o córtex cingulado e parietal. As principais regiões moduladoras da formação das memórias declarativas são a área basolateral do núcleo amigdalino ou amígdala, localizado também no lobo temporal, e as grandes regiões reguladoras dos estados de ânimo, alerta, ansiedade e emoções, localizadas à distância: substância negra, o locus ceruleus, os núcleos da rafe e o núcleo basal de Meynert. Os axônios destas regiões atingem o hipocampo, a amígdala e os córtices entorrinal, cingulado e parietal e liberam, respectivamente, os neurotransmissores, a dopamina, noradrenalina, serotonina e acetilcolina (figura 5) (Izquierdo, 2002; Izquierdo, 2004). 

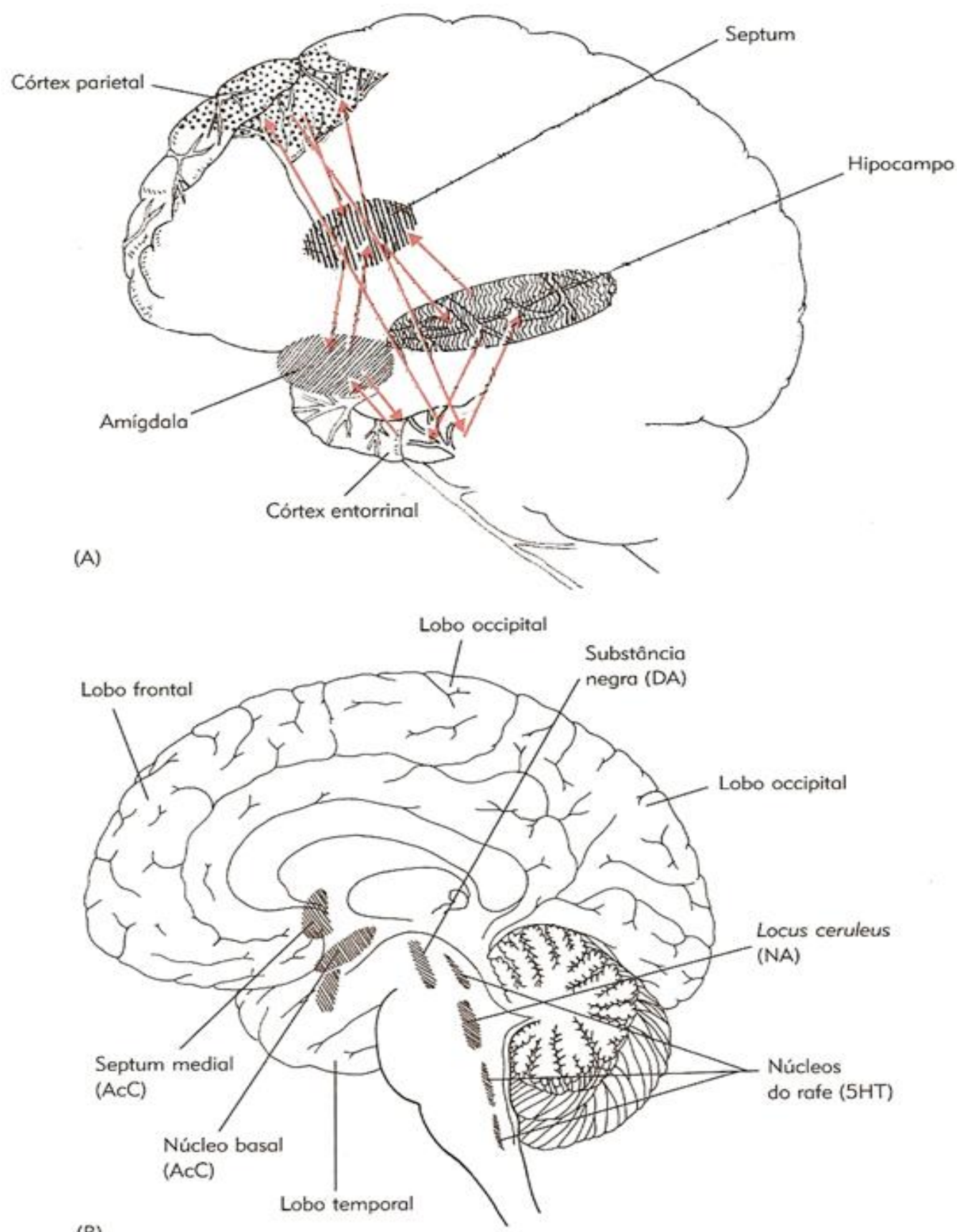

(B)

Figura 4: A: Mapa das principais áreas cerebrais envolvidas no processamento das memórias declarativas. Observe-se que todas essas áreas estão interconectadas entre si e com o hipocampo através do córtex entorrinal. Além disso, todas recebem inervação dos grandes sistemas moduladores: o da dopamina (DA), o da serotonina (5-HT) e acetilcolina (Aco). B: localização dos neurônios dos diversos sistemas moduladores (adaptado de Izquierdo, 2002). 


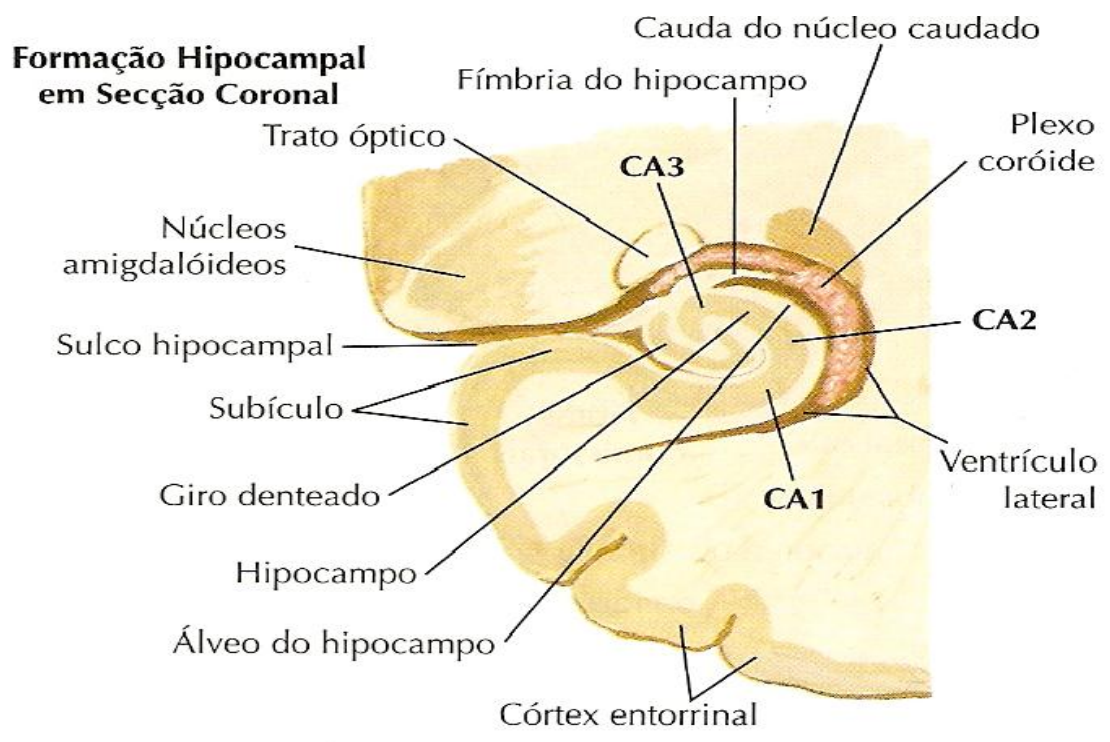

Figura 5: Vista da formação hipocampal em corte coronal (adaptado de Felten e Józefowicz, 2005).

A amígdala basolateral recebe, na hora da formação das memórias, o impacto inicial dos hormônios periféricos (corticóides, adrenalina) liberados na corrente sanguínea pelo estresse ou emoção excessiva. É o núcleo por meio do qual estas substâncias modulam as memórias: sua ativação faz com que estas se gravem, em geral, melhor que outras (Izquierdo, 2002; Izquierdo, 2004).

Os circuitos responsáveis pelas memórias de procedimentos ou implícitas (hábitos) envolvem o núcleo caudado (inervado pela substância negra) e o cerebelo. Algumas destas utilizam circuitos do lobo temporal (hipocampo, córtex entorrinal figura 5) nos primeiros dias depois da aquisição. Esse tipo de memória sofre pouca modulação pelas emoções ou estados de ânimo. A principal modulação é via substância negra - núcleo caudado, que pode explicar, por exemplo, a aparição, aumento ou diminuição de tremores e alterações do tônus muscular, que, muitas 
vezes, são observados quando somos vítimas de tensões emocionais e queremos fazer ou deixar de executar determinado movimento (Izquierdo, 2002; Izquierdo, 2004).

A memória de trabalho é uma memória on-line, varia de instante a instante, utiliza poucas vias nervosas (principalmente o córtex pré-frontal), mantém as informações por poucos segundos, raras vezes, um minuto ou dois, e cumpre uma função gerenciadora de nosso contato com a realidade. Decide entre tudo aquilo que nos acontece, o que guardaremos e não guardaremos na memória declarativa ou na procedural; ou que memória declarativa ou procedural valerá à pena evocar em cada caso (Izquierdo, 2002; Izquierdo, 2004).

Em relação à memória espacial, ratos e camundongos vivem em um mundo constituído de espaços complexos, semelhante a um labirinto. Eles desenvolveram capacidades para construir representações internas das características espaciais dos lugares onde se encontram. No hipocampo, estrutura principal em termos de memória espacial, existe células de lugar, os neurônios piramidais. Cada ambiente no qual o animal se encontra é preenchido por campos de lugar, sobrepostos, de neurônios no hipocampo. Isso significa que cada célula responde a alguma parte do lugar onde o animal está. Este mapa neuronal é estável e basta olhar os campos do local para se especificar a posição do animal no espaço, após exame simultâneo dos padrões de deflagração dos neurônios hipocampais. Assim, para cada lugar haverá um mapa neuronal específico (Thompson, 2005). 


\subsubsection{Mecanismos de formação das memórias}

Os neurônios se comunicam entre si pelos pontos de contato altamente especializados, denominados sinapses. Algumas das mais notáveis atividades do encéfalo, tais como aprendizado e memória, emergem das propriedades sinalizadoras das sinapses. Enquanto o sinal no axônio - o potencial de ação - é um sinal do tipo "tudo ou nada", grande e invariável, o sinal da sinapse - potencial sináptico - é graduado e modificável (Squire e Kandel, 2003; Thompson, 2005).

Uma sinapse típica apresenta três componentes: um terminal pré-sináptico, uma célula alvo pós-sináptica e um pequeno espaço entre estes dois processos, separando os dois neurônios, a fenda sináptica. O terminal pré-sináptico de uma célula se comunica através da fenda sináptica com o corpo celular ou com os dendritos da célula alvo pós-sináptica (Squire e Kandel, 2003; Thompson, 2005).

Para ativar a célula alvo, a corrente produzida pelo potencial de ação na célula pré-sináptica não pode saltar diretamente pela fenda. Em vez disso, o sinal sofre uma grande transformação na sinapse. Quando o potencial de ação atinge o terminal pré-sináptico, o sinal elétrico promove a liberação do neurotransmissor. Essa substância é derramada dentro da fenda sináptica, onde atua como sinal para a célula alvo. Uma vez que este tenha se difundido pela fenda, é reconhecido e se liga a moléculas receptoras na superfície da célula pós-sináptica (Squire e Kandel, 2003; Thompson, 2005). Os neurotransmissores mais comuns utilizados pelas células nervosas são aminoácidos ou seus derivados, como, por exemplo, 
glutamato, ácido gama-aminobutírico (GABA), acetilcolina (Aco), adrenalina, noradrenalina (NA), serotonina (5-HT) e dopamina (DA). A transmissão sináptica ocorre no momento em que o potencial de ação penetra nos terminais présinápticos. Este provoca a abertura de canais para íons cálcio $\left(\mathrm{Ca}^{+2}\right)$ na membrana, causando um grande e rápido aumento deste dentro dos terminais pré-sinápticos. $\mathrm{A}$ elevação da concentração de $\mathrm{Ca}^{+2}$ dentro da célula causa a liberação de neurotransmissor. Este se difunde pela fenda sináptica rumo à pós-sináptica. Finalmente, a interação desta substância com receptores na célula pós-sináptica causa potencial excitatório sináptico despolarizante no neurônio pós-sináptico que, se for grande o suficiente, pode gerar um potencial sináptico (Squire e Kandel, 2003; Thompson, 2005).

Estes sinais neurais são responsáveis pelo início do processo de armazenamento das memórias. O potencial de ação induzirá a liberação de neurotransmissores, que vão se acoplar aos receptores na membrana pós-sináptica, AMPA (ácido alfa-amino-3-hidróxi-5-metil-4-isoxazol-propiônico), do tipo metabotrópico, que libera o monofosfato de adenosina cíclico (AMPc) e NMDA (Nmetil-D-aspartato), do tipo ionotrópico, causador do influxo de $\mathrm{Ca}^{+2}$ para dentro da célula neuronal. O movimento deste íon para o interior da célula pós-sináptica e a liberação de AMPc, segundo mensageiro, ativa mecanismos moleculares responsáveis pelo armazenamento das informações (Squire e Kandel, 2003; Thompson, 2005). 


\subsubsection{Mecanismos moleculares e rotas bioquímicas para formação das memórias}

A formação das memórias de curta e longa duração são processos paralelos, pois a de curta permanece durante o tempo necessário para o término da formação da de longa duração, ao redor de 6 h (Izquierdo, 2002).

A memória de curta duração é formada a partir do estímulo proveniente do mundo exterior, que causa o desencadeamento do potencial de ação. Este ativa os receptores AMPA, NMDA e metabotrópicos, cuja ação é modulada positivamente (facilitada) por colinérgicos muscarínicos, dopaminérgica tipo D1 e $\beta$ noradrenérgicos, e negativamente (inibida) por serotonérgicos do tipo IA. No córtex entorrinal, há intervenção dos glutamatérgicos do tipo AMPA, porém modulação positiva pelos serotonérgicos tipo IA. No parietal, ocorre a intervenção de glutamatérgicos do tipo AMPA. Em CA1, na primeira hora, é necessária a ativação das isoenzimas $\alpha$ e/ou $\beta$ da proteína cinase $C(P K C)$, presumivelmente présinápticas. Ao mesmo tempo, outras isoformas da mesma são ativadas no córtex entorrinal. Além disso, durante os primeiros 90 minutos, é necessária a ativação da proteína cinase A (PKA) no hipocampo. Para tal, a estrutura da proteína G muda sua conformação, após ativação dos receptores citados anteriormente, e ativa a adenilil ciclase, que converte trifosfato de adenosina (ATP) em monosfosfato de adenosina cíclica (AMPc). A concentração de AMPc aumenta e ativa a PKA. Ocorre, consequentemente, o fechamento dos canais de $\mathrm{K}^{+}$(não NMDA), a abertura dos de $\mathrm{Na}^{+}$(receptores AMPA), determinando um alargamento do potencial de ação e, por 
conseguinte, o aumento no influxo de $\mathrm{Ca}^{+2}$, através dos canais de cálcio via receptor NMDA, causando a liberação do neurotransmissor. O AMPc, então, atuando via proteína cinase, dependente de AMPc, modula tanto os canais iônicos quanto a liberação do neurotransmissor. Assim, as conexões sinápticas são reforçadas por todo o período da memória de curta duração (Izquierdo, 2002, Squire e Kandel, 2003).

Em relação à memória espacial, de longa duração, o mecanismo ainda não é bem conhecido. Entretanto, sugere-se que o processo de armazenamento ocorra devido ao potencial de longa duração. O rato, ao ser testado no labirinto de Morris, forma um mapa do local, a partir das pistas penduradas na parede da sala onde está a piscina, com o objetivo de encontrar a plataforma para escapar da água. Este estímulo desencadeia o potencial de ação e causa excitação repetida das células hipocampais na região CA1, por meio da estimulação de receptores AMPA (glutamatérgicos), NMDA e metabotrópicos, assim chamados porque respondem tanto ao glutamato quanto ao ácido amino-hidróxi-metil-isoxazol-propiônico. Os receptores gabaérgicos do tipo A, no hipocampo e córtex entorrinal, inibem o início da formação da memória de longa duração. Simultaneamente, a ativação dos receptores colinérgicos, do tipo muscarínico, e noradrenérgicos, do tipo $\beta$, modula os anteriores. Essa excitação repetida dos neurônios leva à despolarização persistente da célula pós-sináptica. Assim, o receptor AMPA é ativado e há o influxo de $\mathrm{Na}^{+}$para o interior da célula neuronal. Como consequência da despolarização, o tampão de $\mathrm{Mg}^{+2}$ da abertura do canal do receptor NMDA é removido e acontece o influxo de $\mathrm{Ca}^{+2}$, em quantidade suficiente para que haja aumento persistente da 
atividade sináptica. A elevada concentração de $\mathrm{Ca}^{+2}$ estimula direta ou indiretamente uma série de enzimas. A proteína calmodulina cálcio dependente (CaMKII) e a proteína cinase C (PKC) favorecem a fosforilação de receptores glutamatérgicos. Na célula pré-sináptica, a PKC fosforila uma proteína chamada GAP-43, reguladora da liberação de glutamato na região CA1. Ainda, a proteína cinase G (PKG) ativa três enzimas pós-sinápticas: a óxido nítrico sintase, que produz o óxido nítrico (NO), a hemeoxigenase, que produz o monóxido de carbono (CO) e a que produz o fator de ativação plaquetária (FAP). O NO e o CO são gases e se difundem através da membrana rumo àquela pré-sináptica; o FAP é um lipídeo que atravessa a membrana dendrítica e também se dirige à terminação axônica. As três substâncias, por meio de mecanismos que promovem a liberação do glutamato, aumentam a eficiência desta sinapse por vários minutos (fortalecimento da sinapse). Isso potencializa a transmissão glutamatérgica na célula pós-sináptica na região CA1. Além disso, a proteína cinase, ativada por agentes mitógenos (MAPK), que intervém 3h ou mais após a aquisição da tarefa, fosforila o fator de transcrição do ADN presente nos núcleos das células, o CREB-P (do inglês responsive element binding protein - Izquierdo, 2002), bem como hiperfosforila o fator ERK (do inglês, extracellular signal-regulated kinase), em diferentes regiões do córtex entorrinal e do hipocampo, responsável pela consolidação e reconsolidação da memória de longa duração (Kelly e cols., 2003). Do mesmo modo, a proteína cinase A (PKA) intervém duas vezes na formação da memória de longa duração: a primeira, nos primeiros minutos após a aquisição e, a segunda, 2-6 h mais tarde. Ambos os picos de atividade da PKA são acompanhamos por elevação simultânea de CREB-P 
nuclear; o segundo pico de PKA, por aumento de CREB-P nas mitocôndrias póssinápticas. A ativação deste fator leva o núcleo das células pós-sinápticas a produzir ARNm (ácidos ribonucléicos mensageiros), que organizam a síntese de numerosas proteínas. Algumas são fatores de transcrição que retornam para o núcleo. Outras são proteínas de adesão celular, que são transportadas às sinapses destas células, alterando a sua superfície e, portanto, aumentando ou diminuindo a sua função (Izquierdo, 2002, Squire e Kandel, 2003). Especificamente, o segundo pico de PKA, 2-6 h após o início da aquisição da memória, é altamente regulável por receptores dopaminérgicos D1/D5, noradrenérgicos do tipo $\beta$ e, finalmente, serotonérgicos do tipo IA. Os dois primeiros estimulam e os serotonérgicos inibem a enzima adenilil ciclase, que produz AMPc, cofator imprescindível para a ação da PKA. Assim, indiretamente, os receptores D1 e $\beta$ estimulam e os IA inibem a atividade da PKA, levando à facilitação ou depressão da consolidação da memória, respectivamente (Izquierdo, 2002, Squire e Kandel, 2003). Após 12h do evento, ocorre a liberação de dopamina, a partir da área tegmentar ventral. A dopamina ativa a formação hipocampal, que produz BNDF (brain-derived neutrophic factor) necessário para o fortalecimento das sinapses envolvidas (plasticidade sináptica) (Berkinschtein e cols., 2009).

Já a habituação ocorre devido ao processo de depressão sináptica, ou seja, decréscimo na eficácia da transmissão de certas sinapses como resultado de ativação repetida. Isso ocorre através da redução na liberação do neurotransmissor das vesículas, nas terminações nervosas da célula neuronal pré-sináptica na fenda sináptica. A causa desse decremento é a diminuição na entrada de íons $\mathrm{Ca}^{+2}$, na 
terminação nervosa, devido à ação do sistema de segundo mensageiro resultante da ativação repetida (Thompson, 2005).

\subsubsection{Modelos animais para estudo das memórias}

Existem vários testes comportamentais para o estudo das memórias. O teste do reconhecimento espontâneo de objetos (SORT) é um teste classicamente descrito para o estudo da memória de trabalho, do tipo non-matching-to-sample, onde a informação a ser lembrada em cada teste é independente da próxima. Como consequência, é possível testar um animal repetidamente e usar o mesmo para comparar diferentes condições experimentais. Nesse estudo utilizamos esse teste para avaliação da memória discriminativa de curta duração. O teste se baseia na exploração espontânea, diferencial de objetos familiares e novos, logo não existem componentes de memória de referência. O desempenho do reconhecimento é obtido a partir dos tempos gastos (em segundos) na exploração de dois objetos diferentes (conhecido/desconhecido) (Ennaceur e Delacour, 1988). Em relação ao estudo da memória espacial (hipocampal), utilizamos o teste do labirinto de Morris modificado, que é um aparato, no qual o rato é treinado para escapar da água nadando até uma plataforma submersa, sob um fluido opaco. O animal é liberado de uma localização aleatória, próxima à periferia do tanque. Na primeira tentativa, encontrará a plataforma por acaso. Para lembrar onde está a plataforma nas tentativas seguintes, o rato deve utilizar referências espaciais fornecidas por marcas 
nas (quatro) paredes da sala. Animais normais aprendem onde a plataforma está rapidamente (Squire e Kendal, 2003). 


\subsection{Estresse oxidativo}

\subsubsection{Toxicidade do oxigênio $\left(\mathrm{O}_{2}\right)$}

Embora os organismos aeróbios necessitem do $\mathrm{O}_{2}$ do ar para sobreviver, esta substância pode causar danos. Os sinais de toxicidade dependem da espécie, idade, estado fisiológico e dieta. Ratos recém nascidos sobrevivem por mais tempo respirando $\mathrm{O}_{2} 100 \%$ em comparação aos adultos, os quais desenvolvem sofrimento respiratório. Já os humanos adultos ao respirarem $\mathrm{O}_{2}$ por várias horas poderão apresentar dano alveolar e fibrose pulmonar. As altas pressões de $\mathrm{O}_{2}$ causam toxicidade aguda no SNC dos seres humanos, sendo capazes de provocar convulsões em mergulhadores ou pacientes colocados em câmaras hiperbáricas (Halliwell e Gutteridge, 1985; William, 1991; Bondy e Lebel, 1993; Campbell, 2001; Junqueira, 2004; Halliwell e Gutteridge, 2006).

Nos organismos vivos, $\mathrm{o}_{2}$ é utilizado na respiração celular. Esta molécula (95\% do $\mathrm{O}_{2}$ ) é reduzida, de forma completa, via citocromo oxidase, à água através da cadeia respiratória (na mitocôndria), com o intuito de produzir trifosfato de adenosina (ATP). No entanto, os $5 \%$ restantes de oxigênio sofrem reações de redução incompleta (figura 6), gerando espécies ativas de oxigênio (EAO), extremamente reativas e instáveis (quadro 1) (Halliwell, 2006). 


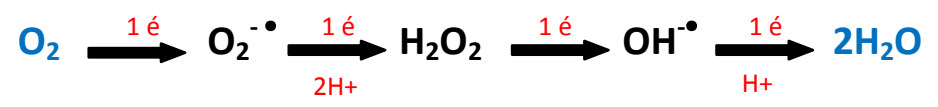

Figura 6. Representação esquemática das reações de redução incompletas do oxigênio à $\mathrm{H}_{2} \mathrm{O}$ (Halliwell e Gutteridge, 1985; Halliwell, 1992; Halliwell e Gutteridge, 2006).

A citocromo oxidase possui íons de metais de transição nos seus sítios ativos - ferro (Fe) e cobre (Cu). Metais de transição, como ferro (Fe), cromo ( $\mathrm{Cr}$ ), níquel (Ni), manganês (Mn), vanádio $(\mathrm{V})$, cobre $(\mathrm{Cu})$, cobalto (Co) e titânio (Ti), apresentam números de oxidação variáveis. A alteração entre estes estados de oxidação permite que estes íons transfiram elétrons e facilitem as reações de oxi-redução. Os mesmos, quando não estão ligados a nenhum sítio de ação, promovem a liberação de EAO (Halliwell, 2006). 
Quadro 1. Exemplos de espécies ativas de oxigênio e nitrogênio (Halliwell e Gutteridge, 1998; Halliwell e Gutteridge, 2006).

\begin{tabular}{|c|c|}
\hline \multicolumn{2}{|c|}{ Espécies ativas de oxigênio } \\
\hline Superóxido $\mathrm{O}_{2}^{-\bullet}$ & Peróxido de hidrogênio $\mathrm{H}_{2} \mathrm{O}_{2}$ \\
\hline Hidroxil $\mathrm{OH}^{-\bullet}$ & Ácido hipocloroso $\mathrm{HOCl}_{4}$ \\
\hline Peroxil $\mathrm{RO}_{2}{ }^{\bullet}$ & Ozônio $\mathrm{O}_{3}$ \\
\hline Alcoxil $\mathrm{RO}^{\bullet}$ & Oxigênio singlet $\mathrm{O}^{1}$ \\
\hline Hidroperoxil $\mathrm{HO}_{2}{ }^{\bullet}$ & Peroxinitrito $\mathrm{ONOO}^{-}$ \\
\hline & Óxido nítrico NO \\
\hline
\end{tabular}

\subsubsection{Tipos de espécies ativas de oxigênio}

\section{Radical ânion superóxido $\left(\mathrm{O}_{2}^{-\bullet}\right)$}

O radical ânion superóxido ocorre em quase todas as células aeróbicas e resulta da ativação máxima de neutrófilos, monócitos, macrófagos e eosinófilos, devido a processos inflamatórios. Apesar de ser considerado pouco reativo em 
soluções aquosas, tem sido observada lesão biológica secundária em sistemas geradores de $\mathrm{O}_{2}^{-\bullet}$ (Ferreira e Matsubara, 1997).

\section{Radical hidroperoxil $\left(\mathrm{HO}_{2}{ }^{\circ}\right)$}

Representa a forma protonada do radical ânion superóxido, ou seja, possui o próton hidrogênio. Existem evidências de que o hidroperoxil é mais reativo do que o ânion superóxido, devido à maior facilidade em danificar membranas biológicas (Ferreira e Matsubara, 1997).

\section{Radical hidroxil $\left(\mathrm{OH}^{-\bullet}\right)$}

A combinação extremamente rápida do $\mathrm{OH}^{\bullet}$ com metais ou outros radicais no próprio sítio onde foi produzido, confirma sua alta reatividade em sistemas biológicos. Assim, se o radical hidroxil for produzido próximo ao ADN e, no mesmo estiver fixado um metal, as bases púricas e pirimídicas sofrerão modificações, levando à inativação ou mutação do ADN. Além disso, este radical inativa várias proteínas (enzimas ou constituintes da membrana celular), ao oxidar seus grupos sulfidrilas (-SH) a pontes dissulfeto (-SS) e, por conseguinte, iniciar a oxidação dos ácidos graxos poliinsaturados das membranas celulares (Ferreira e Matsubara, 1997; Milton, 2004; Perry e cols., 2002). 


\section{Peróxido de hidrogênio $\left(\mathrm{H}_{2} \mathrm{O}_{2}\right)$}

O peróxido de hidrogênio não é espécie radical, pois não possui elétrons

desemparelhados na última camada. É uma molécula que passa para o meio intracelular facilmente através da difusão passiva e participa da reação que produz o radical hidroxil (Ferreira e Matsubara, 1997).

\section{Oxigênio singlet $\left({ }^{1} \mathrm{O}_{2}\right)$}

É a forma excitada do oxigênio molecular e não possui elétrons desemparelhados em sua última camada. $\mathrm{O}^{1} \mathrm{O}_{2}$ tem importância em certos eventos biológicos, mas poucas doenças foram relacionadas à sua presença (Ferreira e Matsubara, 1997).

\subsubsection{Reatividade das espécies ativas de oxigênio}

As EAO reagem com lipídios, proteínas e ADN, danificando as membranas celulares, provocando mutações e acúmulo de produtos de degradação causando a morte celular. Estas reações ocorrem em diferentes órgãos do organismo como o coração, fígado, pulmões, rins, encéfalo entre outros (Halliwell e Gutteridge, 1985; 
William, 1991; Bondy, Lebel, 1993; Campbell, 2001; Junqueira, 2004; Halliwell e Gutteridge, 2006).

A figura 7 mostra a representação esquemática do processo de lipoperoxidação.

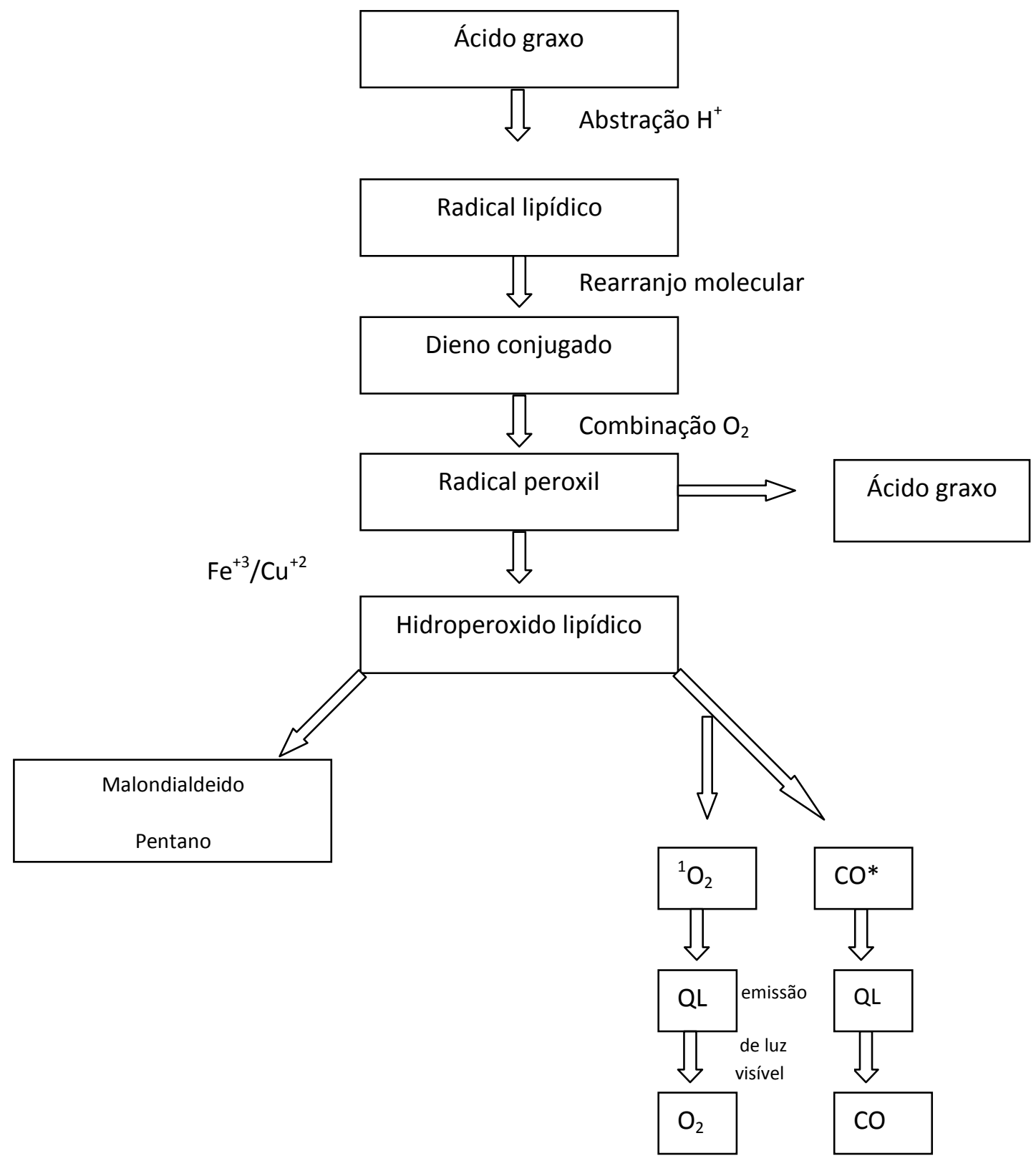

Figura 7: Representação esquemática das etapas da lipoperoxidação de membranas celulares ${ }^{1} \mathrm{O}_{2}=$ oxigênio singlet e $\mathrm{CO}^{*}=$ carbonila excitada (adaptado de Del Maestro, 1980). 
A reação em cascata da lipoperoxidação se divide em três etapas: iniciação, propagação e terminação. Na iniciação, ocorre o ataque das EAO, como o radical hidroxil, aos ácidos graxos poliinsaturados, retirando o átomo de hidrogênio de um metileno $\left(-\mathrm{CH}_{2}-\right)$. A retirada deste átomo resulta na espécie $-\mathrm{CH}^{\bullet}-$, que apresenta um elétron desemparelhado na última camada. Este radical se estabiliza através do rearranjo molecular de um dieno conjugado. Já na segunda etapa, a propagação, os dienos conjugados reagem com o oxigênio, resultando no radical peroxil. Por sua vez, este radical reage com os lipídeos de membrana, formando os lipoperóxidos e, assim, sucessivamente, até a fase da terminação. Na terminação, o peroxil se combina com um átomo de hidrogênio, resultando o hidroperóxido lipídico. Este composto se degrada em maldondialdeído (MDA) e gás pentano, na presença dos íons ferro e cobre. Ainda, o hidroperóxido lipídico libera o oxigênio singlet e as carbonilas excitadas emitem quanta de luz visível para retornar ao seu estado fundamental (Halliwell e Gutteridge, 2006).

O encéfalo é extremamente suscetível ao EO, o qual compreende o desequilíbrio entre a elevada concentração de oxidantes em relação à baixa quantidade de antioxidantes com produção de dano celular (Halliwell, 1992; Halliwell, 2006; Halliwell e Gutteridge, 2006). Especificamente, o encéfalo é formado basicamente por ácidos graxos poliinsaturados e proteínas, os quais podem sofrer lipoperoxidação e oxidação, respectivamente, pelas EAO liberadas durante o processo de neuroinflamação a partir da ativação da microglia. Além disso, os danos provocados pelo EO nas células neuronais promovem a liberação de aminoácidos excitatórios como, por exemplo, o glutamato. Este se liga aos 
receptores dos neurônios adjacentes, causando aumentos excessivos e prolongados de $\mathrm{Ca}^{+2}$ e $\mathrm{Na}^{+}$no meio intracelular, levando à morte celular por necrose. Outros neurotransmissores como a dopamina, seu precursor L-DOPA, serotonina e noradrenalina são auto-oxidáveis. Estes podem reagir com o oxigênio e gerar $\mathrm{O}_{2}^{-\bullet}$ (figura 8 , reação 1). O ânion em questão, após captação de dois prótons $\left(2 \mathrm{H}^{+}\right)$, através da reação de dismutação catalisada pela superóxido dismutase (SOD), forma o $\mathrm{H}_{2} \mathrm{O}_{2}$ (figura 8, reação 2). Do mesmo modo, o metabolismo do cérebro gera $\mathrm{H}_{2} \mathrm{O}_{2}$ através das enzimas monoamino oxidases $\mathrm{A}$ e $\mathrm{B}$, flavoproteínas localizadas nas membranas externas dos neurônios e da glia (Halliwell, 2006).

Além disso, muitas áreas encefálicas - substância negra, núcleo caudado, putâmen, globo pálido - contêm elevadas concentrações de $\mathrm{Fe}^{+2}$. A ferritina, no encéfalo saudável, é responsável pelo seu armazenamento. No entanto, em pacientes portadores da doença de Parkinson, a morte dos neurônios dopaminérgicos da substância negra libera grandes quantidades de ferro, que catalisa a reação de Fenton aumentando a produção de $\mathrm{OH}^{\bullet}$ (figura 8 , reação 3 ) (Halliwell, 2006). 


$$
\begin{aligned}
& \mathrm{O}_{2}+1 \mathrm{e} \Rightarrow \mathrm{O}_{2}^{-\bullet} \\
& 2 \mathrm{O}_{2}^{-\bullet}+2 \mathrm{H}^{+} \mathrm{SOD} \Rightarrow \mathrm{H}_{2} \mathrm{O}_{2}+\mathrm{O}_{2} \\
& \mathrm{Fe}^{+2}+\mathrm{H}_{2} \mathrm{O}_{2} \Rightarrow \mathrm{OH}^{-\bullet}+\mathrm{OH}^{-}+\mathrm{Fe}^{+3} \\
& \mathrm{Cu}^{+1}+\mathrm{H}_{2} \mathrm{O}_{2} \Rightarrow \mathrm{OH}^{-\bullet}+\mathrm{OH}^{-}+\mathrm{Cu}^{+2}
\end{aligned}
$$

Figura 8: Representação esquemática das reações de oxi-redução (1 e 2); reações de Fenton (3 e 4) (Halliwell e Gutteridge, 2006).

Por fim, os níveis de catalase - enzima antioxidante - na maioria das regiões cerebrais são baixos (córtex e cerebelo), exceto na substância negra e hipotálamo, onde são elevados (Halliwell, 2006).

\subsubsection{Espécies ativas de oxigênio e nitrogênio como segundos mensageiros}

Segundos mensageiros são gerados ao mesmo tempo em que o seu respectivo receptor é ativado, apresentam vida curta e agem especificamente em órgãos efetores alterando transitoriamente a sua atividade. EAO (espécies ativas de oxigênio) e EAN (espécies ativas de nitrogênio) podem ser geradas quando o receptor é ativado e apresentam vida curta como outros segundo mensageiros, mas a sua especificidade de ligação aos receptores é difícil de determinar, excetuandose o caso do $\mathrm{NO}^{\circ}$, o qual se liga especificamente ao grupo heme regulatório da guanilil ciclase, resultando na sua ativação. As espécies ativas de oxigênio como o 
radical hidroxil $\left(\mathrm{OH}^{-\bullet}\right)$ não apresentam nenhum tipo de especificidade, podendo reagir com qualquer biomolécula. Outras EAO, como $\mathrm{H}_{2} \mathrm{O}_{2}$ e o ânion superóxido $\left(\mathrm{O}_{2}^{-\bullet}\right)$, não são tão reativas como as outras espécies. $\mathrm{O}_{2} \mathrm{O}_{2}$, uma molécula altamente difusível, que pode ser produzida endogenamente via mecanismos mediados por receptores em muitos tipos de células e é enzimaticamente metabolizado, pode ser considerado um segundo mensageiro, embora seus alvos ainda não tenham sido bem definidos (Forman e cols., 2004; Formam e cols., 2010).

\subsubsection{Defesas antioxidantes}

A melhor defesa para evitar o estresse oxidativo no encéfalo é manter as concentrações de $\mathrm{O}_{2}$ nos níveis ideais. Existem antioxidantes enzimáticos, e não enzimáticos. 


\section{Superóxido dismutase (SOD) e outras enzimas removedoras de peróxidos}

Todas as regiões do SNC contêm SOD, enzimas que removem o $\mathrm{O}_{2}^{-\bullet}$ através da reação de dismutação (figura 9).

$$
2 \mathrm{O}_{2}^{-\bullet}+2 \mathrm{H}^{+} \stackrel{\text { SOD }}{\longrightarrow} \mathrm{H}_{2} \mathrm{O}_{2}+\mathrm{O}_{2}
$$

Figura 9: Representação esquemática da reação de dismutação catalisada pela SOD (Halliwell e Gutteridge, 2006).

Existem dois tipos de SOD: MnSOD, na mitocôndria e ZnCuSOD, no espaço entre as membranas mitocondriais e restante da célula. Estas duas enzimas necessitam de $\mathrm{Mn}, \mathrm{Cu}$ e $\mathrm{Zn}$ como cofatores. Estes micronutrientes ou oligoelementos (os metais essenciais) são provenientes da dieta (Halliwell, 2006). A captação de grande quantidade destes elementos, durante o desenvolvimento fetal, ocorre com o objetivo de garantir a boa formação dos órgãos e sistemas durante a gestação (Halliwell e Gutteridge, 2006).

As SOD devem funcionar em conjunto com enzimas que removam o $\mathrm{H}_{2} \mathrm{O}_{2}$. Catalases detoxificam o $\mathrm{H}_{2} \mathrm{O}_{2}$, porém as concentrações das mesmas são baixas no encéfalo. No entanto, outra enzima, a glutationa peroxidase (GPx), cujo cofator é o selênio (Se), elemento traço essencial proveniente da dieta, remove, 
eficientemente, o $\mathrm{H}_{2} \mathrm{O}_{2}$. A remoção ocorre através da redução do $\mathrm{H}_{2} \mathrm{O}_{2}$ e da oxidação da GSH (Halliwell e Gutteridge, 2006; Halliwell, 2006) (figura 10).

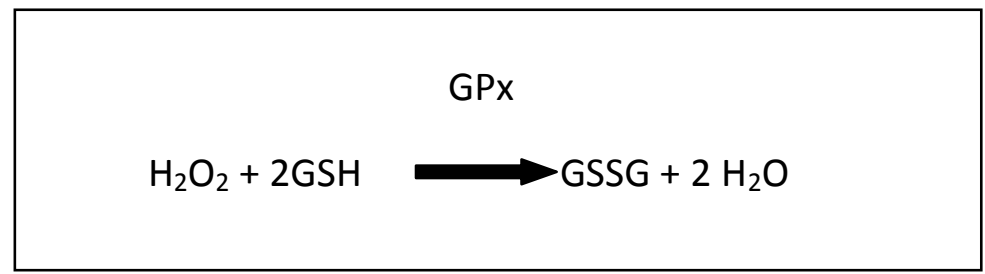

Figura 10: Representação esquemática da reação de oxidação da glutationa e redução do $\mathrm{H}_{2} \mathrm{O}_{2}$ catalisada pela GPx (Halliwell e Gutteridge, 2006).

O produto, a glutationa oxidada (GSSG), que consiste em duas glutationas ligadas através de uma ponte de dissulfeto, é convertido em GSH, novamente, pela glutationa redutase (GRx).

\section{Antioxidantes não enzimáticos}

O encéfalo é rico em antioxidantes de baixo peso molecular, especialmente o ascorbato, um agente redutor. Neurônios e glia possuem sistemas de transporte eficazes, com o objetivo de aumentar a concentração intracelular dessa substância. Assim, as células neuronais captam prontamente o ascorbato e, a glia, o dehidroascorbato, a fim de convertê-lo em ascorbato, no ambiente intracelular (Halliwell e Gutteridge, 2006; Halliwell, 2006). 
O ascorbato doa um elétron e produz o radical ascorbil ou semihidroascorbato (SDA), que pode sofrer oxidação e formar o dihidroascorbato (DHA). A pouca atividade do ascorbil é a essência da propriedade antioxidante do ascorbato: uma espécie ativa de oxigênio interage com o ascorbato e uma substância muito menos reativa é formada. O ascorbil perde um próton, regenerando o ascorbato (Halliwell e Gutteridge, 2006; Halliwell, 2006).

Outra substância importante, a vitamina E, provém de uma família de quatro tocoferóis e quatro tocotrienóis, que inibem a lipoperoxidação através da detoxificação de radicais peroxil $\left(\mathrm{LO}_{2}{ }^{\circ}\right)$, usando o grupo $\mathrm{OH}$ fenólico (figura 11) (Halliwell e Gutteridge, 2006; Halliwell, 2006).

$$
\mathrm{Toc}-\mathrm{OH}+\mathrm{LO}_{2}^{\bullet} \longrightarrow \mathrm{Toc}-\mathrm{O}^{\bullet}+\mathrm{LOOH}
$$

Figura 11: Representação esquemática da reação de detoxificação de lipoperóxido pelo $\alpha$-tocoferol (Halliwell e Gutteridge, 2006; Halliwell, 2006).

No encéfalo, $\alpha$-tocoferol parece ser a única forma de vitamina presente. Este é derivado da lipoproteína de alta densidade (HDL) do plasma. Privação severa e longa desta vitamina lipossolúvel, como ocorre em alguns erros inatos do metabolismo, que afetam a absorção da mesma e outras provenientes da dieta ou o processamento do $\alpha$-tocoferol, produz dano neurológico (Halliwell e Gutteridge, 2006; Halliwell, 2006). 
Apesar das discussões na literatura nutricional, sobre os efeitos protetores dos carotenóides e flavonóides sobre o encéfalo, existem poucas evidências sobre o uso destes como antioxidantes no SNC. Nenhum tipo de carotenóide foi detectado em tecidos humanos, de ratos e macacos, após a suplementação alimentar. Entretanto, os compostos fenólicos, como monofenóis - por exemplo - galato de epigalocatequina, hesperitina, naringenina podem atravessar a BHE. Alguns estudos sugerem um efeito protetor do extrato de Ginkgo biloba, administrado oralmente contra o desenvolvimento da demência. Tais efeitos seriam atribuídos aos flavonóides constituintes desta planta (miricetina e quercetina). Experimentos feitos com camundongos, cujas dietas foram suplementadas com Ginkgo mostraram alterações na expressão gênica neuronal, sugerindo que este extrato ultrapassou a BHE (Halliwell, 2006).

\subsubsection{Estresse oxidativo, doenças neurodegenerativas e poluição do ar}

A poluição do ar é uma das causas de neuroinflamação, de produção das EAO e, possivelmente, das doenças neurodegenerativas. Como citado anteriormente, o encéfalo é vulnerável ao EO devido ao uso de elevadas concentrações de ATP, a fim de suprir a demanda metabólica, baixos níveis de antioxidantes (ascorbato, $\alpha$-tocoferol, catalase) e alto conteúdo de lipídeos e proteínas. 
As doenças neurodegenerativas possuem características em comum: deterioração da função mitocondrial, aumento do dano oxidativo, presença de agregados de proteínas defeituosas, alterações no metabolismo do ferro, excitoxicidade e neuroinflamação.

Os mecanismos, através dos quais o MP causa neuroinflamação e neurodegeneração, não foram completamente elucidados. Entretanto, as células microgliais são responsáveis pela resposta imune, inata do encéfalo, a inflamação (Block e Calderón-Garcidueñas, 2009). Estas se originam a partir de células mielóides, na periferia, e migram para o SNC durante o desenvolvimento embrionário. Grande densidade das mesmas se encontra no hipocampo, telencéfalo e núcleos da base, conforme descrito por Mohankumar e cols. (2008) em estudo com animais. Uma vez ativada por MP, estas passam a apresentar uma morfologia amebóide e induzem à expressão de moléculas de superfície, como receptores de citocinas, complexo de histocompatibilidade e CD14. Além do mais, a microglia ativada produz fatores pró-inflamatórios e neurotóxicos - IL-1ß, fator de necrose tumoral $\alpha$ (TNF $\alpha$ ), NO, $\mathrm{H}_{2} \mathrm{O}_{2}, \mathrm{O}_{2}^{-\bullet}$. A produção do ânion superóxido, no meio extracelular, e a ativação da nicotinamida adenina dinucleotídeo fosfato oxidase (NADPH) são as vias responsáveis pela neurotoxicidade, originada a partir da ação destas células. Além disso, os metais de transição adsorvidos às partículas, como Fe, $\mathrm{Cu}, \mathrm{V}, \mathrm{Cr}, \mathrm{Ni}$, são responsáveis pela conversão do $\mathrm{H}_{2} \mathrm{O}_{2}$, produzido a partir da microglia, em $\mathrm{OH}^{-\bullet}$, através da reação de Fenton (figura 8, reações 3 e 4). As duas EAO $\mathrm{O}_{2}^{-\bullet}$ e $\mathrm{OH}^{-\bullet}$, causam lipoperoxidação dos lipídeos de membrana, diminuição da sua fluidez e consequente morte celular por apoptose (Milton, 2004; Xia e cols., 
2006; Mohankumar e cols., 2008). Calderón-Garcidueñas e cols., (2008a) demonstraram que a exposição de crianças e adultos jovens, cujos óbitos ocorreram repentinamente, às partículas finas e ultrafinas, ocasionou neuroinflamação, alteração da resposta imune inata em áreas importantes do encéfalo e acúmulo de $A \beta 42$ e $\alpha$-sinucleína, características patogênicas do Mal de Alzheimer e da doença de Parkinson, respectivamente, desde a infância. Estes agregados induzem o aumento do $\mathrm{Ca}^{+2}$ intracelular, a atividade da oxido nítrico sintase nos astrócitos e produção de EAO. Todos estes eventos podem levar à morte celular apoptótica (Halliwell, 2006).

Assim, as alterações no metabolismo celular no encéfalo geradas pelo EO induzido pela inalação de MP podem estar relacionadas com a fisiopatologia das doenças neurodegenerativas. 


\section{JUSTIFICATIVA}

O MP está associado a várias doenças. Considerando que: a) o MP desencadeia processo inflamatório sistêmico após a sua deposição nos alvéolos pulmonares; b) a exposição de camundongos fêmea na fase pré-gestacional e gestacional causa aumento na permeabilidade da placenta; c) o MP tanto via sistêmica quanto via bulbo olfatório ativa a microglia e causa a liberação de fatores pró-inflamatórios no encéfalo; d) a redução no quociente de inteligência em crianças com 5 anos de idade se deve à exposição aos HAP; e) crianças e adultos jovens expostos ao MP apresentaram problemas de aprendizado e diminuição no tamanho do córtex pré-frontal; faz-se necessário avaliar a influência da exposição ao MP durante a gestação sobre o estresse oxidativo no encéfalo e a memória em animais adultos. Além disso, investigar se a troca de ambiente no $21^{\circ}$ dia do período pós-natal dos ratos (término da lactação) reverterá o dano oxidativo bem como mnemônico. Este estudo tem o intuito de colaborar para o esclarecimento da relação entre a perda da capacidade de armazenamento de informações e os mecanismos bioquímicos do estresse oxidativo provocados pelo MP. 


\section{OBJETIVOS}

\subsection{Geral}

Determinar as alterações no desenvolvimento, no comportamento e na bioquímica cerebral de ratos machos adultos expostos à poluição atmosférica ambiental nas fases de vida intra-uterina e de lactação.

\subsection{Específicos}

a) Avaliar o desenvolvimento dos filhotes machos expostos ou não à poluição atmosférica ambiental durante a vida intra-uterina e lactação ( $21^{\circ}$ dia de vida) através da pesagem da ninhada ao nascer e ao $7^{\circ}$ dia de vida, da determinação do tempo para a abertura dos olhos e do tempo para o aparecimento da primeira penugem;

b) Estudar as memórias discriminativa de curta duração, de habituação e espacial de ratos machos adultos expostos ou não à poluição ambiental durante a fase intra-uterina e o período de lactação, através da aplicação dos testes de reconhecimento espontâneo de objetos e labirinto modificado de Morris, respectivamente; 
c) Estudar as memórias discriminativa de curta duração, de habituação e espacial de ratos machos adultos expostos ou não à poluição ambiental após o período de lactação e que foram submetidos à troca de ambiente, através da aplicação dos testes de reconhecimento espontâneo de objetos e labirinto modificado de Morris, respectivamente;

d) Avaliar a lipoperoxidação (LPO) no córtex, hipocampo e estriado do encéfalo de ratos machos adultos expostos ou não à poluição atmosférica ambiental durante a fase intra-uterina e o período de lactação, através da determinação da concentração de malondialdeído;

e) Avaliar a lipoperoxidação (LPO) no córtex, hipocampo e estriado do encéfalo de ratos machos adultos expostos ou não à poluição atmosférica ambiental após o período de lactação em que foram submetidos à troca de ambiente, através da determinação da concentração de malondialdeído;

f) Avaliar a atividade das enzimas antioxidantes superóxido dismutase, catalase e a concentração de glutationa total no córtex, hipocampo e estriado do encéfalo de ratos machos adultos expostos ou não à poluição atmosférica ambiental durante a fase intra-uterina e o período de lactação;

g) Avaliar a atividade das enzimas antioxidantes superóxido dismutase, catalase e a concentração de glutationa total no córtex, hipocampo e estriado do encéfalo de ratos machos adultos expostos ou não à poluição atmosférica ambiental após o período de lactação em que foram submetidos à troca de ambiente; 
h) Determinar a concentração de elementos traço tóxicos ( $\mathrm{Cd}, \mathrm{Pb}, \mathrm{Sb})$ no sangue total coletado de ratos machos adultos expostos ou não à poluição atmosférica ambiental durante a fase intra-uterina e do período de lactação;

i) Determinar a concentração de elementos traço tóxicos $(\mathrm{Cd}, \mathrm{Pb}, \mathrm{Sb})$ no sangue total coletado de ratos machos adultos expostos ou não à poluição atmosférica ambiental após o período de lactação em que foram submetidos à troca de ambiente;

j) Determinar a concentração de elementos traço essenciais ( $C u, M n$, Se e Zn) no sangue total coletado de ratos machos adultos expostos ou não à poluição atmosférica ambiental durante a fase intra-uterina e do período de lactação;

k) Determinar a concentração de elementos traço essenciais $(\mathrm{Cu}, \mathrm{Mn}$, Se e Zn) no sangue total coletado de ratos machos adultos expostos ou não à poluição atmosférica ambiental após o período de lactação em que foram submetidos à troca de ambiente;

I) Estimar o número de neurônios e neuroglia do córtex, do hipocampo e do estriado de ratos machos adultos expostos ou não à poluição atmosférica ambiental durante a fase intra-uterina e do período de lactação através de análises histológicas por técnicas esterológicas;

m) Estimar o número de neurônios e neuroglia do córtex, do hipocampo e do estriado de ratos machos adultos expostos ou não à poluição atmosférica 
ambiental após o período de lactação em que foram submetidos à troca de ambiente através de análises histológicas por técnicas esterológicas. 


\section{MATERIAIS E MÉTODOS}

Este trabalho foi desenvolvido de acordo com as normas nacionais e internacionais de cuidados com os animais de laboratório (Goldim, 1995) sendo aprovado pelos comitês de ética da Universidade de São Paulo - CAPPesq -0067/07 e da Universidade Federal de Ciências da Saúde de Porto Alegre - CPA 084/03.

\subsection{Desenho Experimental}

Na figura 12 se encontra o esquema do desenho experimental.

Ratos Wistar adultos $(\mathrm{n}=24)$ com 45 dias de idade foram adquiridos do Instituto de Pesquisas Biológicas do Estado do Rio Grande do Sul. Os machos foram divididos em 2 grupos ( $n=12$ animais por grupo):

Grupo 1: foi mantido em câmara com ar filtrado por 70 dias, com objetivo de realizar um ciclo completo da espermatogênese;

Grupo 2: foi mantido em câmara com ar não filtrado, pelo mesmo período, com igual objetivo.

De forma semelhante, as fêmeas foram divididas em dois grupos ( $n=60$ animais por grupo): 
Grupo 3: foi mantido em câmara com ar filtrado por 15 dias, com o objetivo de adaptar os animais ao ambiente;

Grupo 4: foi mantido em câmara com ar não filtrado pelo mesmo período, com o objetivo de adaptar os animais ao ambiente;

No $71^{\circ}$ dia, foi iniciado o cruzamento entre 1 macho (grupo 1) e 5 fêmeas (grupo 3) (Geração 0 - parental), o que ocorreu durante 13 dias em câmara com ar filtrado. O mesmo procedimento foi adotado com os grupos expostos ao ar não filtrado (grupos 2 e 4).

Após a confirmação de prenhes das fêmeas, através da análise da presença de espermatozóides no esfregaço vaginal e da observação do seu estado geral, estas foram separadas dos machos e acompanhadas durante a gestação (21 dias), em ambas as câmaras. Imediatamente após o parto foram determinados o número total de filhotes, de natimortos e o gênero dos mesmos. Procedeu-se também a pesagem da ninhada ao nascer e, sete dias após o nascimento, para a determinação do peso médio de cada filhote (Rhoden e cols., 2006).

Dos ratos nascidos, apenas os machos (geração $1-\mathrm{G} 1$ ) foram utilizados no experimento, os quais foram subdivididos em 4 grupos experimentais ( $n=24$ animais por grupo):

Grupo 1 (F): nascido em câmara cujo ar era filtrado e mantido na mesma após o desmame ( $21^{\circ}$ de lactação); 
Grupo 2 (NFF): nascido em câmara cujo ar era não filtrado e mantido em câmara com ar filtrado após o desmame $\left(21^{\circ}\right.$ de lactação);

Grupo 3 (FNF): nascido em câmara cujo ar era filtrado e mantido em câmara com ar não filtrado após o desmame ( $21^{\circ}$ de lactação);

Grupo 4 (NF): nascido em câmara cujo ar era não filtrado e mantido na mesma após o desmame $\left(21^{\circ}\right.$ de lactação).

Os animais foram mantidos nas respectivas câmaras por 150 dias. Ao final deste período, os grupos experimentais foram divididos em 3 lotes, conforme a descrição que segue: o primeiro lote (24 ratos; $n=6$ por grupo) foi anestesiado com quetamina (50 mg/Kg) e xilazina (20 mg/Kg), via intraperitoneal (Filho, 2006). 0 tecido neuronal foi fixado através do processo de perfusão cardíaca. Dez minutos antes do início do procedimento, heparina diluída (1:50), na dose de 400UI, via subcutânea (Hafner, 1997), foi administrada aos animais com o objetivo de evitar a coagulação do sangue nos vasos. A toracotomia foi realizada e o coração, exposto. O ventrículo esquerdo foi puncionado com a agulha do cateter conectado a bomba peristáltica. Inicialmente, a circulação sanguínea foi retirada através da lavagem feita com $500 \mathrm{ml}$ de solução fisiológica. Posteriormente, a fixação foi feita através da injeção de $500 \mathrm{ml}$ de solução de paraformaldeído a $4 \%$ (Sigma-Aldrich ${ }^{\circledR}$, SP, Brasil) em tampão fosfato $10 \%, \mathrm{pH} 7,0$ por $1 \mathrm{~h}$. Em ambos os casos, as soluções foram impulsionadas nos vasos através do cateter que se conectava a bomba peristáltica. O encéfalo fixado foi coletado e dissecado em córtex, hipocampo e estriado para a análise histológica por técnicas esterológicas. 
O segundo lote de animais foi utilizado para análise dos comportamentos e do estresse oxidativo (48 ratos, $n=12$ animais por grupo) (itens 4.3 e 4.4 ). Um dia após a realização dos testes comportamentais, os ratos foram eutanasiados por decapitação, o encéfalo foi coletado e dissecado em córtex, hipocampo, estriado e congelado $-80^{\circ} \mathrm{C}$, para, posteriormente, mensurar os parâmetros de estresse oxidativo através das análises bioquímicas.

O terceiro lote (24 animais, $n=6$ animais por grupo) foi utilizado para a determinação dos elementos traço tóxicos e essenciais no sangue total. Os animais foram eutanasiados por decapitação e o sangue troncular foi coletado em tubos contendo $200 \mu \mathrm{l}$ de heparina 5.000.000 UI livres de DNA humano, DNAse, RNAse, RNA (Batista e cols., 2009). 


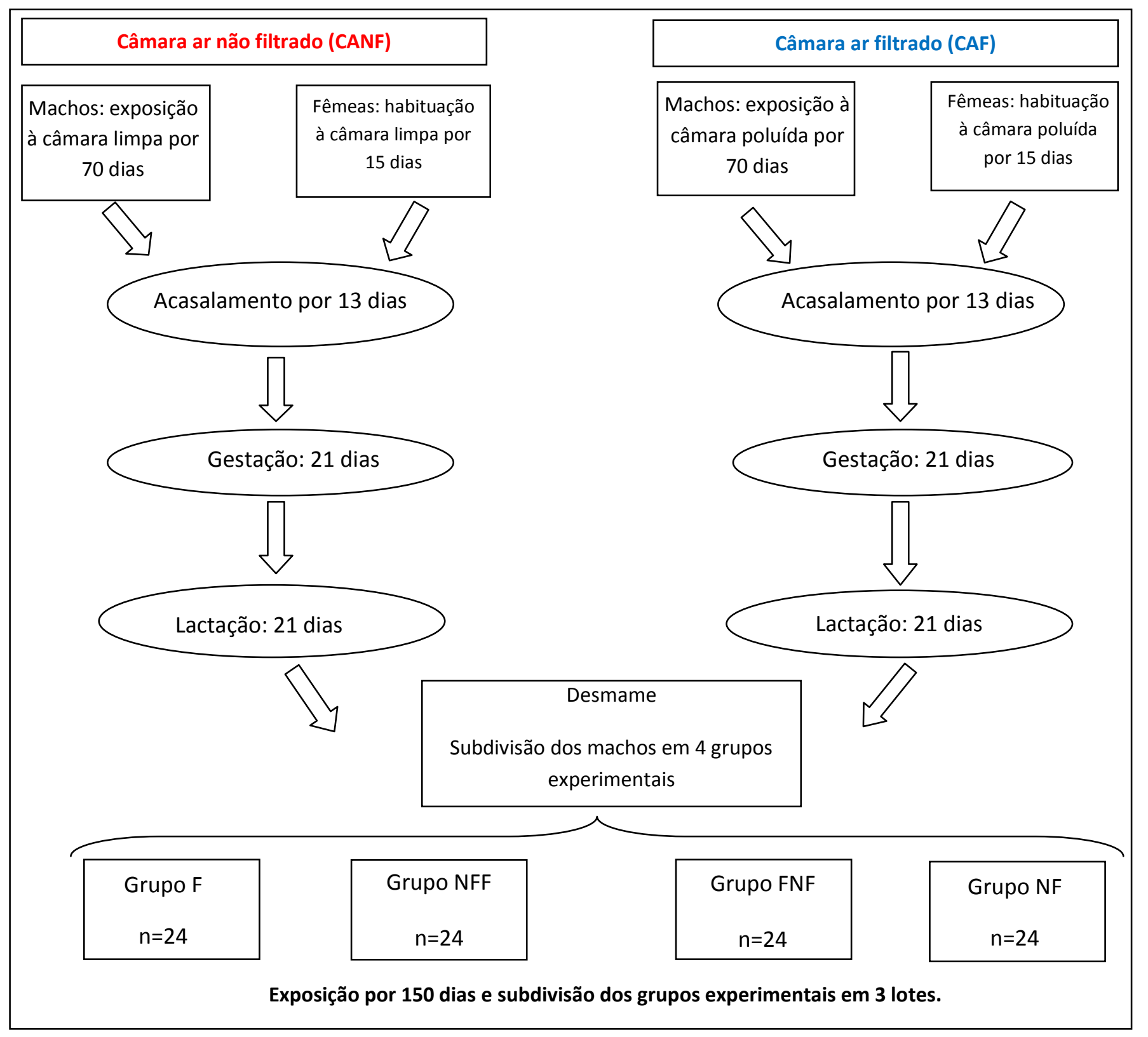

Figura 12: Representação esquemática do desenho experimental. 


\subsection{Câmaras de exposição}

A exposição dos animais à poluição atmosférica ambiental foi feita em câmaras, no período de fevereiro a junho de 2008, no jardim da Universidade Federal de Ciências da Saúde de Porto Alegre, situada em uma avenida com intenso trânsito de veículos, cuja fonte de poluição do ar é predominantemente automotiva. Os grupos de ratos foram mantidos em duas câmaras isoladas $24 \mathrm{~h}$ por dia, durante 150 dias. Uma das câmaras recebeu ar ambiente a 33 I/minuto (câmara poluída) enquanto a outra, localizada no mesmo local, recebeu ar filtrado (câmara limpa) com o mesmo fluxo de ar. Os animais eram mantidos em caixas de polipropileno (47 x 34 × $18 \mathrm{~cm}$ ), em ambiente controlado (ciclo claro-escuro $12 \mathrm{~h}, 8 \mathrm{~h}$ às $20 \mathrm{~h}$ e temperatura $22^{\circ} \pm 2^{\circ} \mathrm{C}$ ) e com livre acesso à alimentação (dieta convencional, Laboratório Supra, Alisul Alimentos S.A., Brasil) e à agua.

As câmaras (dimensões 2,54 x 1,92 x 2,42 m), hermeticamente fechadas, foram construídas em metal e cobertas com filme plástico específico para proteção contra a radiação ultravioleta (figuras 13 e 14). O ar era forçado para dentro (pressão positiva) através dos ventiladores das duas máquinas de fluxo de ar contínuo (Purafil ${ }^{\otimes}$ side access TAG B07-8338, Borges e Katayama, Brasil), refrigerado por ar-condicionado Springer-Carrier ${ }^{\circledR}, 30.000$ Btus de potência, introduzido e distribuído através de aberturas $(47 \times 22 \mathrm{~cm})$ no interior de cada câmara. A saída do ar ocorria através das janelas laterais independentes (120 x 38 cm), em ambas as câmaras. O sistema era normobárico e a pressão no interior das mesmas não excedia à atmosférica em mais de $3 \mathrm{~cm}$ de água. A câmara com o ar 
não filtrado (CANF) apresentava somente um pré-filtro (uma barreira de proteção contra folhas, pássaros, insetos entre outros), cuja eficiência era de $30 \%$. Já a câmara com ar filtrado (CAF) apresentava cinco séries de filtros em linha, inseridos no sistema de fluxo de ar contínuo na seguinte seqüência: pré-filtro, semelhante ao descrito anteriormente; filtro bolsa, que retinha partículas grossas em suspensão no ar (eficiência de 60\%); filtro de carvão ativado (Puracarb ${ }^{\circledR}$ ), que apresentava capacidade de neutralização de $20 \%, 5 \%$ e $8 \%$ para os gases $\mathrm{H}_{2} \mathrm{~S}, \mathrm{SO}_{2}, \mathrm{Cl}_{2}$ respectivamente; filtro químico de permanganato de potássio (Purafil Chemi Select ${ }^{\circledR}$ ), que apresentava capacidade de neutralização de $14 \%, 7 \%$ e $4,9 \%$ para os gases $\mathrm{H}_{2} \mathrm{~S}, \mathrm{SO}_{2}, \mathrm{NO}$, respectivamente e, por fim, os filtros de alta eficiência para material particulado (MP) em suspensão no ar (HEPA: high efficiency particulate air) que retinham 99,97\% da poeira e do material particulado com diâmetro aerodinâmico até 0,3 $\mu \mathrm{m}$ (Borges e Katayama, Brasil). 


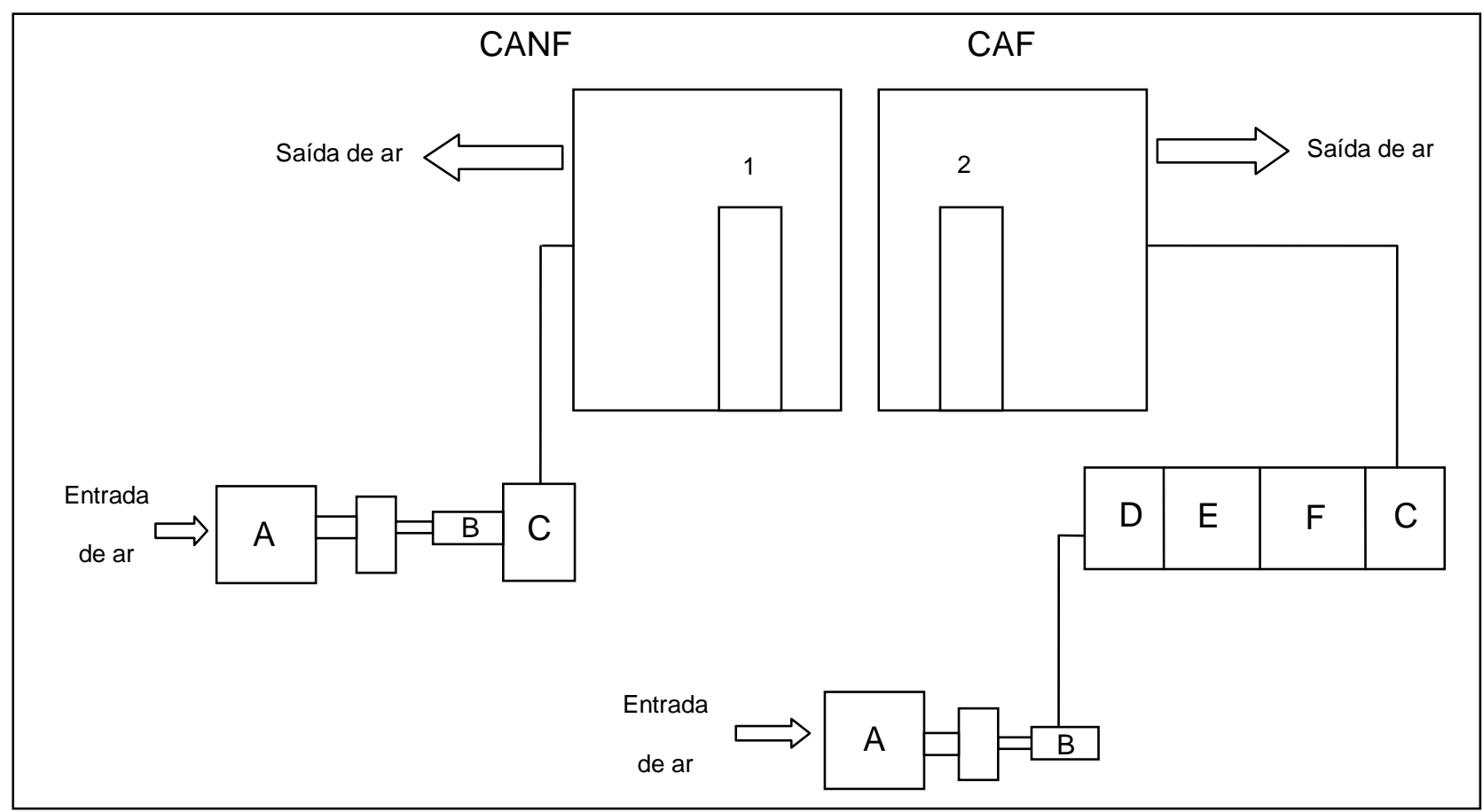

Figura 13: Representação esquemática das câmaras de exposição. CANF: câmara com ar não filtrado; CAF: câmara com ar filtrado. A: pré-filtro; B: ventiladores; $C$ : ar-condicionado; $D$ : filtro de carvão ativado; $E$ : filtro de permanganato de potássio; F: filtros HEPA. 1 e 2: estantes para acondicionamento das caixas moradia dos animais (Esquema idealizado pelo Engenheiro Paulo Afonso de André - Laboratório de Poluição Experimental FMUSP - USP).

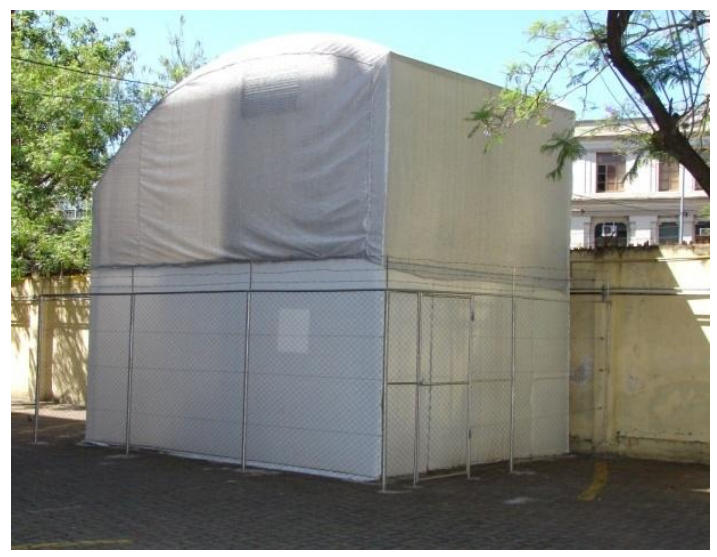

Figura 14: Vista externa das câmaras de exposição (foto cedida pela Professora Cláudia Ramos Rhoden - Laboratório de Estresse Oxidativo e Poluição Atmosférica - UFCSPA). 


\subsection{Testes comportamentais}

\subsubsection{Teste do Reconhecimento Espontâneo de Objetos (SORT)}

O aparato do SORT consta de uma arena para testagem de $65 \times 45 \times 45 \mathrm{~cm}$

de cor neutra e opaca, cujo fundo é forrado com papel pardo (figura 15). Uma câmera para a filmagem foi colocada sobre o aparato, a fim de registrar os comportamentos em DVD. Os objetos utilizados para o reconhecimento estão em triplicata e são pesados, para impedir o seu deslocamento durante o teste. Após a sua utilização, os objetos são higienizados com solução hidroalcoólica $50 \%$, para evitar a interferência de odores no comportamento exploratório. A análise da duração do comportamento exploratório de cada animal, em vídeo, é feita com o auxílio do programa Wabehav, por pesquisador cego para os grupos de tratamento.

No presente estudo, os animais foram submetidos a uma sessão de habituação de 3 minutos, na arena de testagem, sem os objetos, $24 \mathrm{~h}$ antes do início do teste. Após este período de adaptação, a sessão de treino foi realizada e consistiu na colocação do rato na arena para exploração de dois objetos idênticos $\left(A_{1}\right.$ e $\left.A_{2}\right)$ durante 3 minutos. Quarenta e cinco minutos após a sessão de treino, o teste foi realizado, o qual consistiu na colocação do animal na arena para exploração de objetos diferentes entre si $\left(A_{3}\right.$ e $\left.B_{1}\right)$, embora um deles $\left(A_{3}\right)$, considerado familiar e sempre localizado à esquerda da arena, fosse idêntico aos objetos da sessão de treino. Foi considerado comportamento exploratório o 
"cheirar o objeto" numa distância igual ou menor do que $2 \mathrm{~cm}$ ou tocá-lo com o nariz (Ennaceur e Delacour, 1988; Bernardi e Barros, 2004).

As fórmulas para o cálculo dos índices, a partir dos resultados obtidos, estão resumidas na tabela 1 (Ennaceur e cols., 1989). Os índices denominados exploratórios e representados por $\boldsymbol{e}$ medem a exploração ou "cheirar" no treino $\left(\boldsymbol{e}_{1}\right)$ e teste $\left(\boldsymbol{e}_{2}\right)$. Estes índices foram resultado da soma da duração em segundos do "cheirar" ambos os objetos em cada sessão. O índice de habituação, representado por $\boldsymbol{h}$, foi obtido através da diferença do tempo médio (s) gasto na exploração dos objetos no treino com o tempo médio (s) gasto na exploração dos objetos no teste. O índice de discriminação, representado por $\boldsymbol{d}$, foi determinado através da razão entre a diferença na exploração entre os objetos novo e familiar e o tempo total de exploração dos dois objetos no teste (fase de escolha) (Ennaceur e cols., 1989).

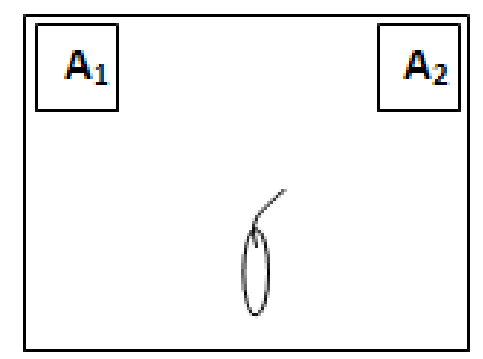

TREINO (1 dia- 3minutos)

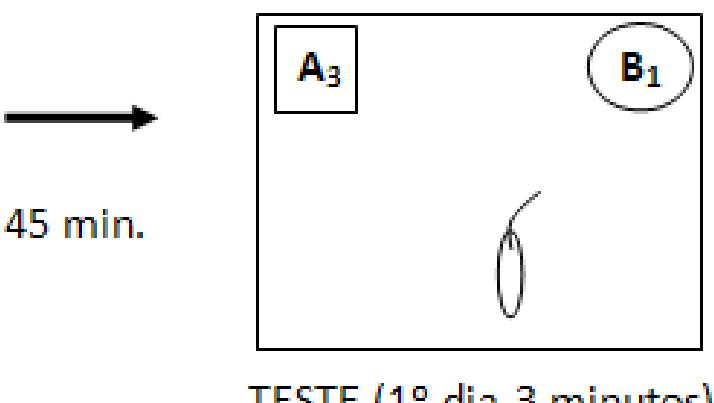

TESTE (1 dia-3 minutos)

Figura 15: Representação esquemática do Teste do Reconhecimento Espontâneo de Objetos. A representa o objeto familiar e B, o objeto novo. 
Tabela 1: Fórmulas utilizadas no cálculo dos índices do Teste do Reconhecimento Espontâneo de Objetos.

\begin{tabular}{llll}
\hline Sessões & exploração & habituação & discriminação \\
& de objetos & aos objetos & entre os objetos \\
\hline Treino & $\boldsymbol{e}_{1}=\mathrm{A}_{1}+\mathrm{A}_{2}$ & & \\
\hline Teste & $\boldsymbol{e}_{2}=\mathrm{A}_{3}+\mathrm{B}_{1}$ & $\boldsymbol{h}=\left(\mathrm{e}_{1}-\mathrm{e}_{2}\right)$ & $\boldsymbol{d}=\left(\mathrm{B}_{1}-\mathrm{A}_{3}\right) /\left(\mathrm{B}_{1}+\mathrm{A}_{3}\right)$
\end{tabular}

$A_{1}, A_{2}$ e $A_{3}$ são objetos em triplicata (iguais). $A_{1}, A_{2}$ são assim designados pela sua utilização no treino, onde o animal compara objetos iguais. $A_{3}$ é o objeto familiar que será comparado com um diferente ou não-familiar $\left(B_{1}\right)$, na sessão de teste.

\subsubsection{Labirinto de Morris modificado}

Antes do início do teste, a temperatura da água foi corrigida para $26^{\circ} \mathrm{C} \mathrm{e}$ esta foi turvada com leite em pó para evitar que o animal distinguisse entre a superfície da água e a plataforma. A referida plataforma foi mantida a $2 \mathrm{~cm}$ abaixo do nível da água, na mesma posição, durante todo o teste. O animal foi colocado em um ponto aleatoriamente escolhido dentre os cinco marcados na beira da piscina (figura 16), com o focinho virado para a borda. O rato foi liberado para nadar durante $300 \mathrm{~s}$ ou até que atingisse a plataforma, onde era mantido por $30 \mathrm{~s}$. Se o animal não atingisse a plataforma em 300s, era guiado até a mesma e mantido sobre ela por $30 \mathrm{~s}$. O mesmo procedimento foi realizado mais quatro vezes, sempre alterando o ponto de partida. Ao término do teste, o rato foi retirado da água, secado e colocado novamente em sua caixa moradia (Abel e Hanningan, 1992). 


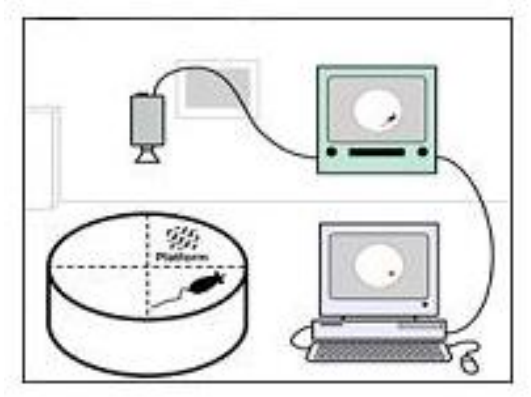

Figura 16: Representação esquemática do labirinto de Morris.

\subsection{Análises do estresse oxidativo}

\subsubsection{Determinação da Lipoperoxidação}

\section{Preparação dos homogeneizados das estruturas cerebrais}

O córtex, hipocampo e estriado foram descongelados, pesados em balança analítica e homogeneizados em tampão $\mathrm{KPi}(\mathrm{KCl} 1,15 \%)$, pH 7,4, na proporção $9 \mathrm{ml}$ $1 \mathrm{~g}$ de tecido. As proteases foram inativadas com a adição de fluoreto de fenilmetanosulfonil (Sigma-Aldrich ${ }^{\circledR}, \mathrm{SP}$, Brasil) $0,5 \mathrm{mM}$ em etanol anidro $(1 \mu \mathrm{l}$ de $\mathrm{PMSF} / 1 \mathrm{ml}$ de tampão $\mathrm{KPi})$. A homogeneização foi realizada manualmente em macerador de vidro, com pistilo de teflon, contando 30 movimentos de rotação e de compressão das estruturas (Neves, 1997). A seguir, os homogeneizados foram centrifugados a $3.000 \mathrm{~g}$ por 10 minutos a $6^{\circ} \mathrm{C}$ e os sobrenadantes foram utlizados 
para a determinação de malondialdeído, atividades da catalase e da superóxidodismutase (SOD) e da glutationa total.

\section{Determinação das proteínas totais pelo método de Bradford}

Esta técnica baseia-se na interação entre o corante comassie brilliant blue BG 250 (Sigma-Aldrich ${ }^{\circledR}$, SP, Brasil) e as macromoléculas protéicas que contém aminoácidos de cadeias laterais básicas ou aromáticas. A interação entre a proteína de alto peso molecular e o corante provoca o deslocamento no equilíbrio deste para a forma aniônica, que absorve fortemente a $595 \mathrm{~nm}$ (Schleicher e Wieland, 1978). Para a dosagem protéica no tecido neuronal, $10 \mu \mathrm{l}$ de homogeneizado da amostra foram diluídos em $190 \mu$ de água destilada. Foram colocados $20 \mu \mathrm{l}$ desta solução em cubetas de plástico (caminho óptico: $10 \mathrm{~mm}$ ), contendo $1 \mathrm{ml}$ de reagente de Bradford. As absorbâncias das amostras foram determinadas a $595 \mathrm{~nm}$, em espectrofotômetro Lambda 35 (Perkin-Elmer do Brasil, SP, Brasil). A curva padrão de proteína foi obtida a partir de concentrações conhecidas da solução padrão de albumina bovina $(1 \mathrm{mg} / \mathrm{ml})$. 


\section{Determinação de malondialdeído (MDA) através do teste das Substâncias Reativas ao Ácido Tiobarbitúrico (TBARS)}

Esta técnica se baseia no princípio de que o MDA forma complexos ácidos de coloração rósea com o ácido tiobarbitúrico que absorvem fortemente a $535 \mathrm{~nm}$. A $125 \mu \mathrm{l}$ de homogeneizado tecidual foram adicionados $375 \mu \mathrm{l}$ de solução de ácido tricloroacético, 10\% para promover a precipitação das proteínas. Após $10 \mathrm{~s}$ de agitação no vórtex, os tubos permaneceram em banho de gelo por 30 minutos e foram centrifugados em centrífuga refrigerada a $3.000 \mathrm{~g}$ por 10 minutos a $6^{\circ} \mathrm{C}$. Em tubos de vidro foram colocados $250 \mu \mathrm{l}$ do sobrenadante e $250 \mu \mathrm{l}$ de ácido tiobarbitúrico 0, 670\% (Sigma, St. Louis, MO, EUA), conforme Neves (1997). A solução foi agitada no vórtex por $10 \mathrm{~s}$ e aquecida a $100^{\circ} \mathrm{C}$ em banho-maria por 15 minutos. Após o resfriamento em banho de gelo, foram acrescentados $750 \mu \mathrm{l}$ de $\mathrm{n}$ butanol para extrair o MDA, de coloração rósea característica. Após a agitação no vórtex por $10 \mathrm{~s}$ e centrifugação a $3.000 \mathrm{~g}$ por 5 minutos a $6^{\circ} \mathrm{C}$, o sobrenadante corado foi colocado em microcubetas de vidro - caminho óptico (CO): $5 \mathrm{~mm}$ - para a determinação da absorbância a 535 nm no espectrofotômetro Lambda 35 (PerkinElmer do Brasil, SP, Brasil). A concentração de MDA em cada cubeta foi expressa em nmol por mg de proteínas totais (Neves, 1997). Para o cálculo da concentração de MDA, foi utilizada a curva padrão de absorbâncias, gerada a partir de concentrações conhecidas do padrão de 1, 1, 3, 3-tetrametoxipropano (Sigma-Aldrich ${ }^{\circledR}$, SP, Brasil) $100 \mathrm{nmol} / \mathrm{ml}$ em solução de $\mathrm{H}_{2} \mathrm{SO}_{4} 1 \%$. 


\subsubsection{Determinação da atividade da superóxido dismutase (SOD)}

A atividade da SOD foi determinada de acordo com Marklund e Marklund (1974) a 420 nm. Esta reação consiste na inibição da auto-oxidação do pirogalol pela atividade da SOD. Uma unidade de SOD é definida como a quantidade de enzima capaz de inibir 50\% da reação. Em cubeta de plástico (CO: $10 \mathrm{~mm}$ ), foram colocados $930 \mu \mathrm{l}$ de tampão TRIS (TRIS 50 mM/EDTA 1 mM; pH 8,2), $4 \mu$ de catalase $30 \mu \mathrm{M}$ e $50 \mu \mathrm{l}$ de homogeneizado tecidual. Após, $16 \mu \mathrm{l}$ de pirogalol, $24 \mathrm{mM}$ em HCl $10 \mathrm{mM}$ foram adicionados à solução. As absorbâncias das amostras foram determinadas no espectrofotômetro Lambda 35 (Perkin-Elmer do Brasil, SP, Brasil), a 420 nm em 60 e $120 \mathrm{~s}$. Os resultados foram expressos em unidades de SOD/mg de proteínas totais (Marklund e Marklund, 1974).

\subsubsection{Determinação da atividade da catalase (CAT)}

A concentração da CAT foi determinada através da decomposição do peróxido de hidrogênio a $25^{\circ} \mathrm{C}$. Em cubeta de quartzo (CO: $10 \mathrm{~mm}$ ), foram colocados $2865 \mu \mathrm{l}$ de tampão fosfato $50 \mathrm{mM}(\mathrm{pH} \mathrm{7,0)} \mathrm{e} 30 \mu \mathrm{l}$ do homogeneizado tecidual. Após, $35 \mu$ l de peróxido de hidrogênio 0,02M foram adicionados à solução. As absorbâncias das amostras foram mensuradas em espectrofotômetro (PerkinElmer do Brasil, SP, Brasil), a $240 \mathrm{~nm}$ (faixa do ultravioleta) e os resultados foram expressos em $\mathrm{pmol} / \mathrm{mg}$ de proteínas totais (Aebi, 1984). 


\subsubsection{Determinação da concentração de glutationa total (GSHt)}

A glutationa total (glutationa reduzida + glutationa oxidada) foi determinada através do Kit Sigma CS0260 (Saint Louis, Missouri, EUA). Os homogeneizados teciduais foram desproteinizados com solução de ácido 5-sulfosalicílico a 5\% e centrifugados a $3.000 \mathrm{~g}$ por $10 \mathrm{~min}$, para remover o precipitado de proteínas. A seguir, a análise para a determinação da concentração da glutationa total foi feita através do ensaio de velocidade da reação enzimática, na qual quantidades de glutationa total ( 2 nmoles) causaram uma redução contínua de 1 nmol de ácido 5, 5’ ditiobis -2- nitrobenzóico (DTNB) para 2 nmoles de ácido 5-tio-2-nitrobenzóico (TNB) e a glutationa oxidada (GSSG) foi reciclada pela glutationa redutase e pelo NADPH. A velocidade da reação é diretamente proporcional a concentração de glutationa total acima de $2 \mu \mathrm{M}$. O produto amarelo (TNB) é mensurado espectrofotometricamente a 412 nm (Lambda 35, Perkin-Elmer do Brasil, SP, Brasil). A curva de calibração de glutationa reduzida foi utilizada para determinar a quantidade de glutationa total nos homogeneizados teciduais. Os resultados foram expressos em nmol por $1 \mathrm{ml}$ de amostra (Tietze, 1969). 


\subsection{Determinação das concentrações de elementos traço tóxicos e essenciais no sangue total}

Amostras de sangue total (100 $\mu \mathrm{l})$ foram diluídas na proporção de 1:50 em solução contendo 0,01\% (v/v) Triton ${ }^{\circledR}$ X-100 e 0,5\% (v/v) de ácido nítrico. Logo em seguida, foram analisadas diretamente por espectrometria de massas, com plasma indutivamente acoplado equipado com célula de reação (DAC-ICP-MS ELAN DRC II, Perkin-Elmer, SCIEX, Norwalk, CT, EUA), cuja operação foi feita com argônio (pureza 99,999\%, Praxair, Brasil) e amônio como gás de reação (99,999\%, Praxair, Brasil), tendo o ródio como padrão interno via ICP. Esta tecnologia apresenta limites de detecção extremamente baixos (< 10 ppt para 20 elementos) (Batista e cols., 2009).

\subsection{Análises histológicas por técnicas estereológicas}

O encéfalo foi retirado e fixado em paraformaldeído $4 \%$ em tampão fosfato, pH 7,0 e dissecado conforme descrito no item 4.1 para a obtenção dos seus pesos úmidos que foram convertidos em volume da estrutura (volume total do órgão $=$ peso úmido $\mathrm{x}$ fator de retração do tecido). 


\subsubsection{Córtex}

O procedimento de amostragem para inclusão do córtex foi baseado no princípio do sistema uniforme randomizado (SUR) (Mayhew 2006; 2008) e no princípio do fractionator, onde o córtex foi seccionado em fatias de $2 \mathrm{~mm}$ de espessura, em série, e novamente em fragmentos menores, como demonstrado nas figuras 17 e 18, para gerar cortes (SUR) (Baddeley 1986). O número médio de fragmentos de tecido após as seç̧ões foi de 12 (dependendo do tamanho do córtex). Os fragmentos alinhados foram divididos em dois grupos, pares e ímpares, para inclusão em parafina, formando dois blocos com uma média de 6 fragmentos emblocados aleatoriamente.

Em seguida, os fragmentos foram desidratados em gradiente etanólico $\left(70^{\circ}\right.$ a $100^{\circ}$ ), diafanizados em xilol e incluídos em um mesmo bloco de parafina aleatoriamente. Para obtenção dos cortes, foi utilizado o princípio do método disector (Gundersen e cols., 1988), pelo qual foram obtidas duas lâminas com 2 pares de cortes seriados de $5 \mu \mathrm{m}$ em cada uma com um intervalo de $150 \mu \mathrm{m}$ entre eles, como demonstrado na figura 19 (em micrótomo Leica ${ }^{\circledR}$ RM2065), e corados pela Hematoxilina de Harris para a realização de análises estereológicas. 

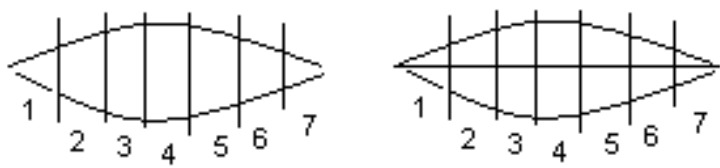

Figura 17: Representação esquemática do método Fractionator - o córtex foi seccionado em fatias de $2 \mathrm{~mm}$ de espessura em série e novamente em fragmentos menores para gerar cortes (SUR) (Baddeley 1986).

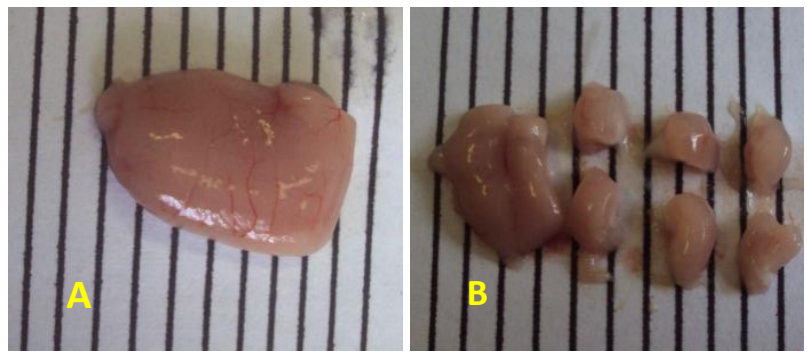

Figura 18: Método utilizado para a obtenção dos cortes do córtex de $2 \mathrm{~mm}$ de espessura em série. A: córtex; B: cortes de 2 × $2 \mathrm{~mm}$.
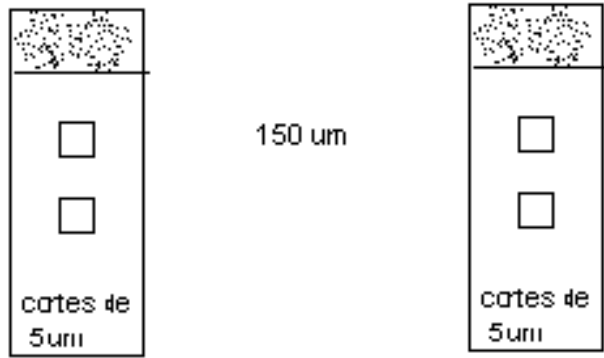

Figura 19: Representação esquemática - método disector (Gundersen e cols. 1988) 2 pares de cortes de $5 \mu \mathrm{m}$ seriados na mesma lâmina com um intervalo de $150 \mu \mathrm{m}$ entre eles 
Um fragmento do córtex com espessura média de $3 \mathrm{~mm}$, com peso úmido de $0,0253 \mathrm{~g}$, foi incluído em parafina, de acordo com o protocolo citado anteriormente para a obtenção da densidade específica do tecido e do fator de retração, devido ao processo de inclusão pelo princípio de Cavalieri (Gundersen e Jansen, 1987). Foram obtidos 8 cortes de $7 \mu \mathrm{m}$, com intervalo de $210 \mu \mathrm{m}$ (30 cortes) entre eles.

\subsubsection{Hipocampo}

O hipocampo é uma estrutura que apresenta três áreas distintas, por isso, dois fragmentos dessa estrutura foram incluídos em parafina no plano longitudinal, como demonstrado na figura 20, para a obtenção dos cortes verticais.

Eixo vertical

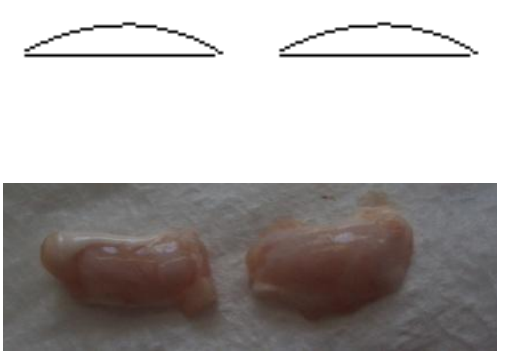

Figura 20: Cortes do hipocampo no plano longitudinal. 
Em seguida, os fragmentos foram desidratados em gradiente etanólico $\left(70^{\circ}\right.$ a $100^{\circ}$ ), diafanizados em xilol e incluídos em um mesmo bloco de parafina longitudinalmente. Para obtenção dos cortes, foi utilizado o princípio do método disector (Gundersen e cols., 1988) pelo qual foram obtidas duas lâminas com 2 pares de cortes seriados de $5 \mu \mathrm{m}$ em cada uma, com um intervalo de $100 \mu \mathrm{m}$ entre eles, conforme demonstrado na figura 21 (em micrótomo Leica ${ }^{\circledR}$ RM2065), e corados pela Hematoxilina de Harris para a realização de análises estereológicas.

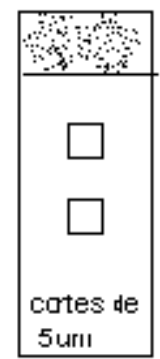

100 um

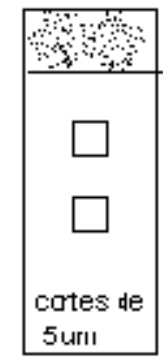

Figura 21: Representação - método disector (Gundersen e cols. 1988) - 2 pares de cortes de $5 \mu \mathrm{m}$ seriados na mesma lâmina com um intervalo de $100 \mu \mathrm{m}$ entre eles.

\subsubsection{Estriado}

O estriado é uma estrutura não homogênea com duas áreas distintas morfologicamente, assim os dois fragmentos foram incluídos aleatoriamente no mesmo bloco de parafina.

Em seguida, os fragmentos foram desidratados em gradiente etanólico $\left(70^{\circ}\right.$ a $100^{\circ}$ ), diafanizados em xilol e incluídos aleatoriamente em um mesmo bloco de 
parafina. Para obtenção dos cortes, foi utilizado o princípio do método disector (Gundersen e cols., 1988), pelo qual foram obtidas duas lâminas com 2 pares de cortes seriados de $5 \mu \mathrm{m}$ em cada lâmina, com um intervalo de $150 \mu \mathrm{m}$ entre eles, conforme demonstrado na figura 22 (em micrótomo Leica ${ }^{\circledR}$ RM2065), e corados pela Hematoxilina de Harris para a realização de análises estereológicas.

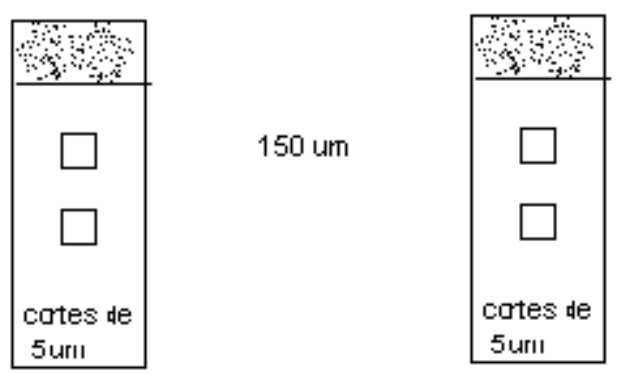

Figura 22: Representação esquemática - método disector (Gundersen e cols. 1988) - 2 pares de cortes de $5 \mu \mathrm{m}$ seriados na mesma lâmina com um intervalo de $150 \mu \mathrm{m}$ entre eles.

\subsubsection{Coloração}

\section{Procedimento técnico}

Os cortes histológicos foram desparafinados em xilol, hidratados em gradiente etanólico (100 a 70) e água e, em seguida, foram corados durante 2 minutos pela Hematoxilina de Harris. Os cortes foram lavados em água corrente e contra corados com eosina, durante quinze minutos. A seguir, os mesmos foram lavados novamente em água corrente, desidratados em gradiente etanólico $\left(70^{\circ} \mathrm{a}\right.$ 
$\left.100^{\circ}\right)$, diafanizados em xilol e montados com lamínula e entellan para análise microscópica.

\subsubsection{Obtenção das imagens e análises estereológicas do córtex cerebral, estriado e hipocampo}

Fragmentos do córtex, estriado e hipocampo, provenientes de 6 animais de cada grupo experimental, corados pelo método da hematoxilina-eosina foram avaliados. O estudo foi realizado com auxílio do programa de análises de imagens digitais Nikon ${ }^{\circledR}$ ACT-2U Imaging Software acoplado a um microscópio de luz Nikon Opitphot $^{\circledR}$

a) Cálculo do Volume total pelo fresh weight

Os pesos úmidos de cada estrutura encefálica - córtex, estriado e hipocampo - foram utilizados para o cálculo do volume total de cada uma através da seguinte fórmula (1):

(1) $V=m / d$

Onde V: volume, m: massa e d: densidade específica do tecido $(1,05)$ (Veras e cols., 2008). 
b) Obtenção da densidade específica do tecido e o fator de retração pelo princípio de Cavalieri

O fator de retração é calculado porque, durante o processamento histológico, ocorre a retração do tecido (Dorph-Petersen e cols., 2001). Para isso, imagens totais dos fragmentos do córtex foram obtidas e capturadas em objetiva de $2,5 x$, permitindo a visualização completa da amostra. Um retículo de $200 \times 200$ (área associada ao ponto $=48.400 \mu \mathrm{m}^{2}$ ) foi sobreposto sobre as imagens, o número de pontos incidentes sobre a estrutura foi contado (Howard, 2005) e o princípio de Cavalieri aplicado, de acordo com a seguinte fórmula (2):

(2) $V t c=t \cdot a(p) \cdot \Sigma P$

Onde t é o comprimento total do córtex (número de cortes multiplicado pela espessura dos cortes), a(p): a área associada ao ponto, e $\sum \mathrm{P}$ : somatório de pontos incidentes no córtex como um todo. 
O índice de retração do tecido, após a inclusão em parafina foi obtido através do cálculo do Shrinkage (3) (Dorph-Petersen e cols., 2001):

(3) $S=V i-V c / V c$

Onde Vi é o volume pelo fresh Peso e Vc é o volume por Cavalieri.

\subsubsection{Quantificação do número de neurônios e neuroglia no córtex e estriado}

A quantificação do número de neurônios e neuroglia foi feita a partir da técnica do disector físico, conforme descrito por Mayhew e colaboradores (2006; 2008).

Para tal, foram utilizados cortes consecutivos de espessura de $5 \mu \mathrm{m}$ corados por hematoxilina-eosina. Cada lâmina do córtex continha, no mínimo, 4 fragmentos histológicos, sendo escolhido, aleatoriamente, dois campos por fragmento e do estriado, 2 fragmentos sendo escolhido, aleatoriamente, 4 campos por fragmento (aumento de 200x), em um total de 8 campos histológicos. Imagens digitais foram obtidas de cada campo, assim como do seu campo correspondente no corte histológico seguinte (consecutiva). O programa Nikon ACT-2U Imaging Software foi utilizado para a captura das imagens. 
A fim de realizar a contagem do número de neurônios e neuroglia, os campos correspondentes foram analisados em ambos os cortes, em locais onde foi possível visualizar as mesmas estruturas. Cada par de disector foi formado pela secção superior ou reference plane e seu correspondente na inferior ou look-up section. Os pares do disector foram limitados por linhas, formando um quadrado de área fixa e conhecida (counting frame - área de $2.500 \mu \mathrm{m}^{2}$ ). As linhas do quadrado foram denominadas de inclusion lines (acima e à direita) e exclusion lines (abaixo e à esquerda). As células presentes no reference plane, mas não na look-up section, e que não tocavam as exclusion lines, foram contadas (Sterio, 1984).

\subsubsection{Quantificação do número de neurônios e neuroglia na região CA1 do hipocampo}

A quantificação do número de neurônios e neuroglia foi feita a partir da técnica do disector físico, conforme descrito por Mayhew e colaboradores (2006; 2008).

Para tal, foram utilizados cortes consecutivos de espessura de $5 \mu \mathrm{m}$ corados por hematoxilina-eosina. Cada lâmina do hipocampo continha 2 fragmentos histológicos, sendo escolhido, aleatoriamente, 4 campos por fragmento na região CA1 (aumento de 200x), em um total de 8 campos histológicos. Imagens digitais foram obtidas de cada campo, assim como do seu campo correspondente no corte 
histológico seguinte (consecutiva). O programa Nikon ACT-2U Imaging Software foi utilizado para a captura das imagens.

A fim de realizar a contagem do número de neurônios e neuroglia, os campos correspondentes foram analisados em ambos os cortes, em locais onde foi possível visualizar as mesmas estruturas. Cada par de disector foi formado pela secção superior ou reference plane e seu correspondente na inferior ou look-up section. Os pares do disector foram limitados por linhas, formando um quadrado de área fixa e conhecida (counting frame - área de $2.500 \mu \mathrm{m}^{2}$ ). As linhas do quadrado foram denominadas de inclusion lines (acima e à direita) e exclusion lines (abaixo e à esquerda). As células presentes no reference plane, mas não na look-up section, e que não tocavam as exclusion lines, foram contadas (Sterio, 1984). 
4.6.8 Fórmulas para cálculo do número de neurônios e neuroglia das estruturas analisadas

O número total de neurônios e neuroglia do córtex e estriado foi estimado através das seguintes fórmulas:
(4) $\mathrm{D}=\mathrm{N} / \mathrm{Vt}$

Onde D é a densidade dos neurônios ou neuroglia contados; N, o número de neurônios ou neuroglia contados e Vt é o volume total do disector.

Logo, o número total de células neuronais ou neurogliais foi obtido através da fórmula 5:

(5) $\mathrm{Nt}=\mathrm{DxVt}$

Onde Nt é o número total de células; $\mathrm{D}$, a densidade numérica dos neurônios ou neuroglia contados e Vt, volume total do encéfalo (Lawers e cols., 2008). 
Por fim, o número total de neurônios e neuroglia da região CA1 do hipocampo foi estimado através da fórmula 6:

(6) $N=1 /$ ssf $\times 1 /$ asf $\times 1 /$ hsf $\Sigma Q^{-}$

Onde $\Sigma Q^{-}$é o número total de neurônios ou de neuroglia contado, ssf é a fração do corte que foi amostrado, asf = área do frame/(distância do núcleo neuronal em relação ao eixo x) x (distância do núcleo neuronal em relação ao eixo y), ou seja, a fração de área amostrada, e hsf é o comprimento da fração amostrada (Hosseini-Sharifabad e Nyengaard, 2007).

\subsection{Análise estatística}

A análise estatística foi realizada utilizando-se o software Sigma Stat ${ }^{\circledR} 3.11$ (Systat Software Inc. 2004, Port Richmond, EUA). Os resultados são expressos em médias, erros padrões (EP) ou desvios padrões (DP) para cada grupo, conforme indicado nas legendas dos gráficos.

A análise de variância (ANOVA) de uma via seguida de teste Post hoc de Student Newman Keuls foi utilizada para fazer comparações múltiplas entre os parâmetros de estresse oxidativo dos quatro grupos.

A análise dos índices de habituação e de memória discriminativa foi feita através da ANOVA seguida do teste Post hoc de Student Newman Keuls, para 
comparações múltiplas entre os quatro grupos. ANOVA de duas vias foi realizada com o objetivo de determinar a interação entre as variáveis comportamentais estudadas e o ambiente onde os animais nasceram e viveram, após o $21^{\circ}$ dia de lactação (desmame).

Para o tempo de latência que o animal demandou, com o objetivo de encontrar a plataforma (teste do Labirinto de Morris), foi realizada ANOVA de uma via seguida do teste Post hoc de Student Newman Keuls para comparações múltiplas entre os quatro grupos. ANOVA de duas vias foi realizada para determinar a interação entre a posição em que o rato era colocado, o tempo de latência e os quatro grupos experimentais.

ANOVA de uma via foi utilizada, seguida do teste Post hoc de Student Newman Keuls, para fazer comparações múltiplas entre os resultados dos quatro grupos das análises histológicas por técnicas estereológicas. A mesma análise foi realizada para comparações múltiplas das concentrações dos metais no sangue dos quatro grupos experimentais.

O nível de significância adotado foi de 5\%. 


\section{RESULTADOS}

\subsection{Avaliação do desenvolvimento e caracterização da prole}

A caracterização da prole, quanto ao desenvolvimento, foi determinada através dos pesos médios das ninhadas e de cada filhote ao nascer e no $7^{\circ}$ dia do período pós-natal e do tempo (em dias) para a abertura dos olhos e para o aparecimento da primeira penugem (tabela 2). Não houve diferença significativa entre os grupos nascidos nas câmaras cujo ar era filtrado (CAF) e não filtrado (CANF). Os números totais de filhotes, bem como de machos e de fêmeas foram semelhantes em ambos os ambientes (tabela 2). Além disso, não houve natimortos em nenhum dos grupos (filtrado e não filtrado) (tabela 2). 
Tabela 2: Avaliação do desenvolvimento de ratos machos expostos ou não à poluição atmosférica a nível ambiental durante a vida intra-uterina e o período de lactação.

\begin{tabular}{|c|c|c|c|}
\hline $\begin{array}{c}\text { Parâmetros de } \\
\text { desenvolvimento e } \\
\text { caracterização da prole }\end{array}$ & CAF & CANF & $\mathrm{P}$ \\
\hline Número total de filhotes & $8,7 \pm 0,603$ & $8,8 \pm 0,526$ & $\begin{array}{l}\mathrm{P}=0,901^{\mathrm{a}} \\
\mathrm{t}_{(38)}=0,125\end{array}$ \\
\hline Número total de natimortos & 0 & 0 & $\begin{array}{c}P=1,000^{a} \\
t_{(38)}=0\end{array}$ \\
\hline $\begin{array}{l}\text { Tempo para abertura dos olhos } \\
\text { (dias) }\end{array}$ & $13,771 \pm 0,646$ & $13,200 \pm 0,569$ & $\begin{array}{l}P=0,565^{a} \\
t_{(71)}=0,578\end{array}$ \\
\hline $\begin{array}{c}\text { Tempo para aparecimento da } \\
\text { primeira penugem (dias) }\end{array}$ & $8,373 \pm 0,527$ & $7,864 \pm 0,417$ & $\begin{array}{l}P=0,461 \\
t_{(93)}=0,741\end{array}$ \\
\hline Peso das ninhadas (g) (dia zero) & $55,000 \pm 3,441$ & $55,000 \pm 3,839$ & $\begin{array}{c}P=1,000^{a} \\
t_{(38)}=0\end{array}$ \\
\hline Peso das ninhadas (g) (dia 7) & $108,750 \pm 8,750$ & $114,500 \pm 6,229$ & $\begin{array}{l}P=0,596 a \\
t_{(38)}=0,535\end{array}$ \\
\hline \multirow[t]{2}{*}{$\begin{array}{l}\text { Média de peso de cada filhote } \\
\text { (g) }\end{array}$} & Peso CAF (0): 6,587 $\pm 0,224$ & Peso CANF $(0): 6,230 \pm 0,368$ & $\begin{array}{c}P=0,413^{a} \\
t_{(38)}=-0,828\end{array}$ \\
\hline & Peso CAF (7): $12,485 \pm 0,605$ & Peso CANF (7): $13,160 \pm 0,459$ & $\begin{array}{l}\mathrm{P}=0,379^{\mathrm{a}} \\
\mathrm{t}_{(38)}=0,889\end{array}$ \\
\hline \multirow[t]{2}{*}{ Número de fêmeas e de machos } & $\mathrm{N}_{\text {(CAF: fêmeas) }}: 3,978 \pm 0,427$ & $N_{\text {(CANF: fềmeas) }}: 4,333 \pm 0,427$ & $\mathrm{P}=0,891^{\mathrm{b}}$ \\
\hline & $\mathrm{N}_{\text {(CAF: machos) }}: 4,022 \pm 0,341$ & $\mathrm{~N}_{\text {(CANF: machos) }}: 3,944 \pm 0.380$ & $F_{(1 ; 90)}=0,00481$ \\
\hline
\end{tabular}

Valores expressos como média comparação entre CAF (câmara ar filtrado) e CANF (câmara ar não filtrado) para número total de filhotes, número de natimortos, tempo para a abertura dos olhos (dias), tempo para aparecimento da primeira penugem (dias); ${ }^{\text {a }}$ teste $t$ de Student para comparação entre grupo Peso $F(0)$ (peso total dos filhotes no dia do nascimento (zero) - grupo filtrado) e Peso NF (0) (peso total dos filhotes no dia do nascimento (zero) - grupo não filtrado) e comparação entre Peso $F(7)$ (peso total dos filhotes no $7^{\circ}$ após o nascimento - grupo filtrado) e Peso ${ }_{N F}(7)$ (peso total dos filhotes no $7^{\circ}$ após o nascimento - grupo não filtrado). ${ }^{b}$ ANOVA 1 via para comparação entre o números (N) de fêmeas e machos das duas câmaras: $\mathrm{N}_{\text {(CAF: fêmeas) }} \mathrm{N}_{\text {(CANF:fêmeas) }} \mathrm{N}_{\text {(CAF: machos); }}$ $\mathrm{N}_{\text {(CANF: machos). }}$. 


\subsection{Testes comportamentais}

\subsubsection{Teste do Reconhecimento Espontâneo de Objetos (SORT)}

\section{a) Habituação}

No presente estudo, observamos que os animais do grupo NF apresentaram maior habituação ao ambiente do teste de reconhecimento espontâneo de objetos $\left(P=0,001 ; F_{(3 ; 23)}=7,941\right)$ quando comparados aos demais grupos experimentais (gráfico 1). Observamos, também, interação entre o local de nascimento e a troca de ambiente após o $21^{\circ}$ dia do período pós-natal $\left(P=0,035 ; F_{(1 ; 23)}=5,087\right)$, ou seja, os animais que nasceram em ambiente cujo ar era filtrado e trocaram de ambiente no $21^{\circ}$ dia do período pós-natal, permanecendo sob ar não filtrado (grupo FNF) habituaram mais do que os animais dos grupos F e NFF. 


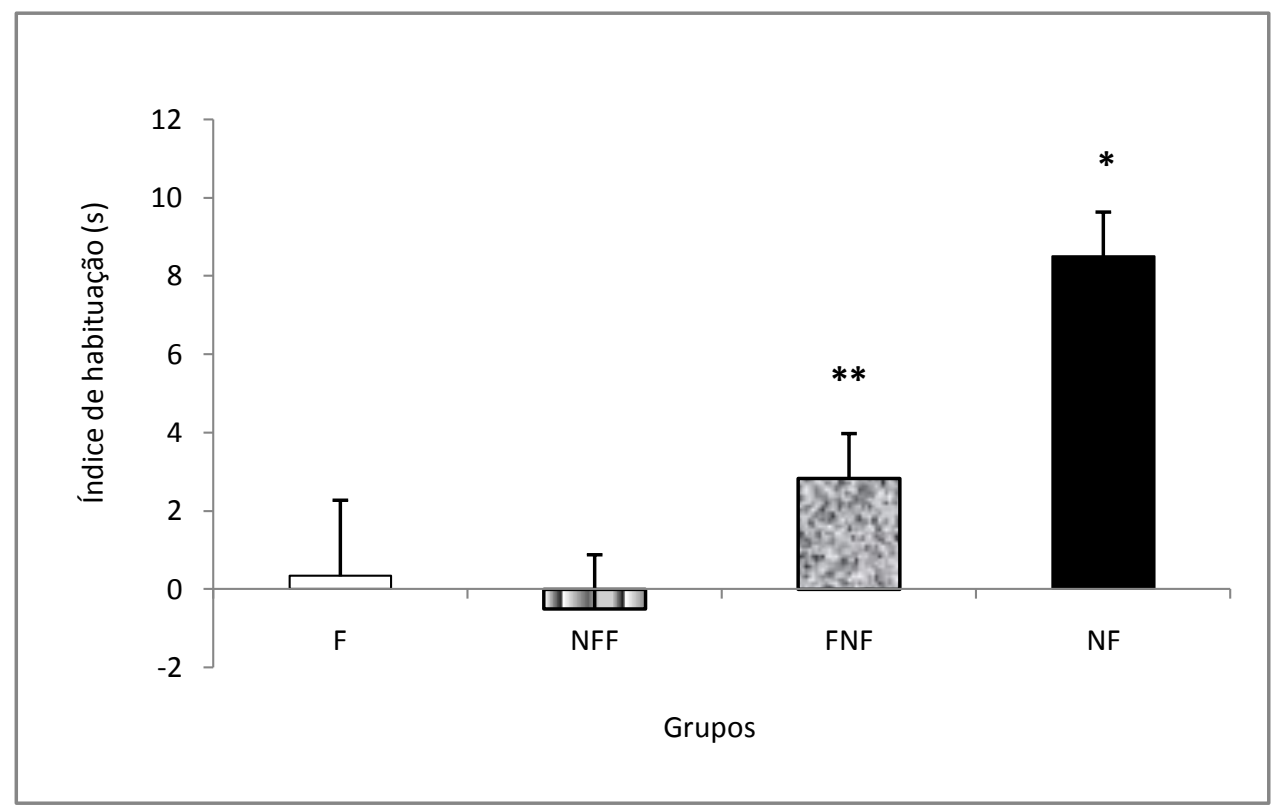

Gráfico 1: Representação gráfica do índice de habituação de ratos adultos expostos ou não à poluição atmosférica a nível ambiental durante a fase intra-uterina e o período de lactação. Grupos experimentais: F (filtrado), NFF (não filtrado/filtrado), FNF (filtrado/não filtrado), NF (não filtrado). Resultados expressos em média \pm erro padrão. ANOVA 1 via seguido de Student Newman Keuls: *diferença significativa do índice de habituação do grupo NF após comparação com os grupos F, NFF e FNF $(P=0,001)$. ANOVA 2 vias para determinar a interação entre o local de nascimento e a troca de ambiente a partir do $21^{\circ}$ dia do período pós-natal: ${ }^{* *}$ o grupo FNF apresentou interação entre os referidos parâmetros $(P=0,035)$.

\section{b) Memória discriminativa de curta duração}

O nosso estudo mostrou que os animais do grupo que foi gestado e mantido em câmara com ar não filtrado (NF), ao serem comparados com os outros grupos, não conseguiram discriminar entre objeto familiar e novo $\left(P=0,006 ; F_{(3 ; 24)}=5,479-\right.$ gráfico 2) revelando comprometimento da memória discriminativa de curta duração. 


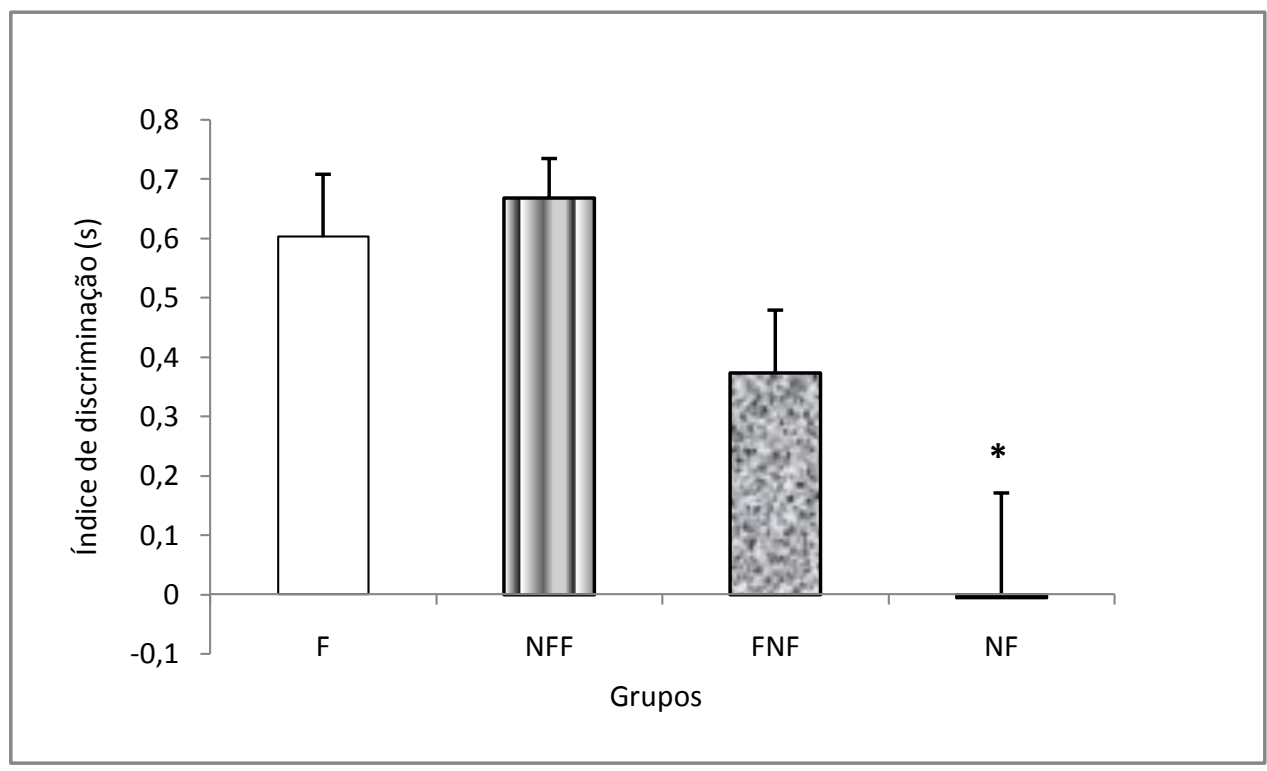

Gráfico 2: Representação gráfica do índice de discriminação de ratos adultos expostos ou não à poluição atmosférica a nível ambiental durante a fase intrauterina e o período de lactação. Grupos experimentais: F (filtrado), NFF (não filtrado/filtrado), FNF (filtrado/não filtrado), NF (não filtrado). Resultados expressos em média \pm erro padrão. ANOVA 1 via seguido de Student Newman Keuls: * diferença significativa do índice de discriminação do grupo NF após comparação com os grupos $F$, NFF e FNF $(P=0,006)$. ANOVA 2 vias para determinar a interação entre o local de nascimento e a troca de ambiente a partir do $21^{\circ}$ do período pósnatal: não houve interação entre os dois parâmetros $(P=0,095)$.

Embora não tenhamos encontrado interação entre o local de nascimento e a troca de ambiente a partir do $21^{\circ}$ dia do período pós-natal $(P=0,095 ; F(1 ; 24)=3,051)$, observamos que os animais submetidos à troca parecem ter modificado os seus respectivos índices de discriminação. 


\subsubsection{Labirinto de Morris modificado}

\section{a) Comparação entre os tempos de latência dos grupos}

O gráfico 3 apresenta o desempenho dos animais deste estudo no labirinto de Morris modificado. Os tempos de latência (em segundos) para encontrar a plataforma não diferiram entre os grupos $\left(P=0,463 ; F_{(3 ; 214)}=0,859\right)$. Entretanto, houve redução significativa no tempo de latência para encontrar a plataforma a partir da primeira posição em comparação ao tempo gasto em outras posições $\left(P=0,001 ; F_{(4 ; 214)}=5,006\right)$, demonstrando que a exposição pré-natal a poluição do ar a nível ambiental até o $21^{\circ}$ dia do período pós-natal não modificou o aprendizado e a memória espacial estudados por este teste. 


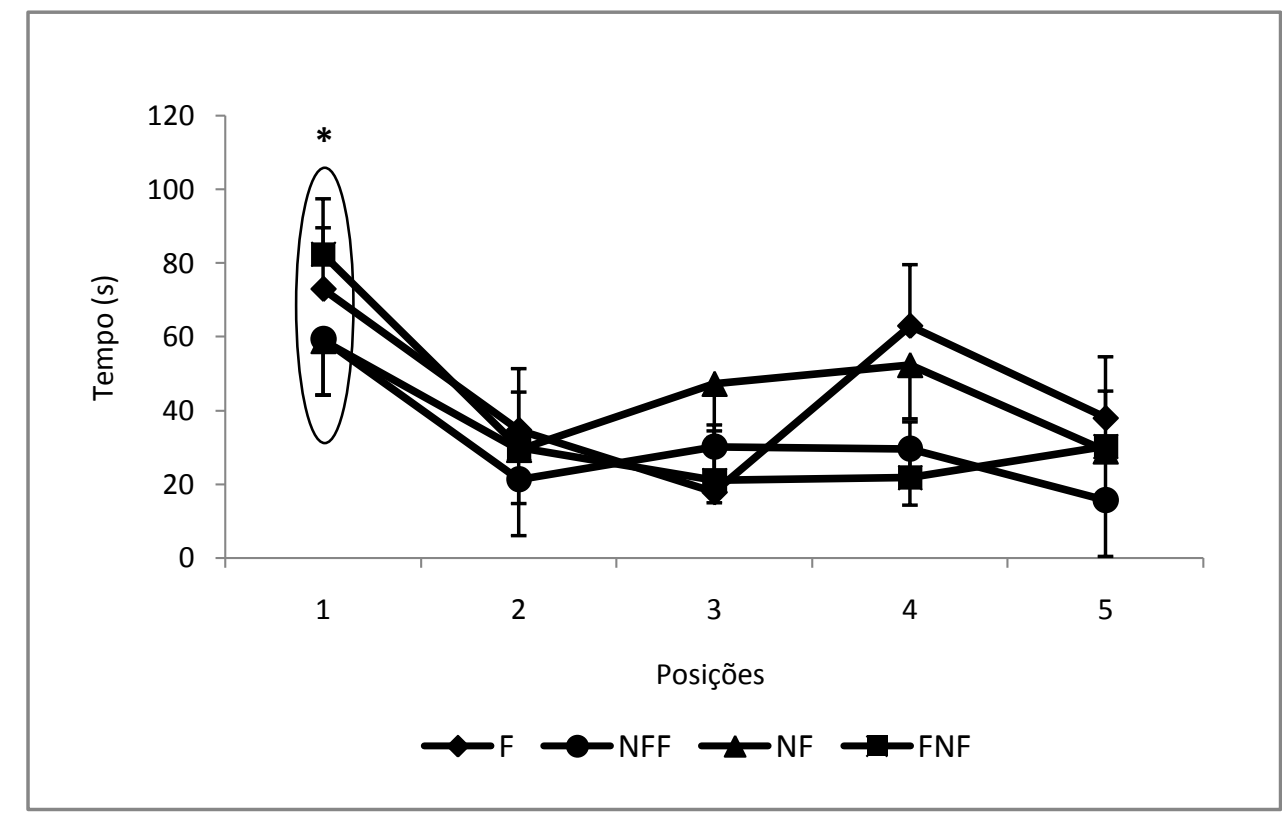

Gráfico 3: Representação gráfica dos tempos de latência para encontrar a plataforma de escape a partir de diferentes posições no labirinto de Morris de ratos adultos expostos ou não à poluição atmosférica a nível ambiental durante a fase intra-uterina e o período de lactação. Grupos experimentais: F (filtrado), NFF (não filtrado/filtrado), FNF (filtrado/não filtrado), NF (não filtrado). Resultados expressos em média \pm erro padrão. ANOVA 1 via: *diferença significativa entre a posição de partida número 1 e as demais $(P=0,001)$. 


\title{
5.3 Análises do estresse oxidativo
}

\begin{abstract}
Para avaliação do estresse oxidativo nas estruturas encefálicas, determinamos a concentração de malondialdeído (MDA) (marcador de lipoperoxidação), da atividade das enzimas antioxidantes (SOD e CAT) e a concentração de glutationa total (GSHt).
\end{abstract}

Em relação ao córtex, verificamos que a concentração de MDA do grupo NF apresentou aumento significativo quando comparada aos outros grupos $(P=0,007$; $\left.F_{(3 ; 26)}=5,219\right)$. A SOD apresentou atividade elevada no grupo $F$ em relação aos demais grupos $\left(P=0,012 ; F_{(3 ; 29)}=4,416\right)$. No entanto, não houve diferença significativa na atividade de catalase entre os grupos estudados $\left(P=0,440 ; F_{(3}\right.$; 23) $=0,941$ ). Quanto ao GSHt, o grupo FNF apresentou baixa concentração desse composto, quando comparado aos demais grupos de animais $\left(P=0,003 ; F_{(3 ;}\right.$ 24) $=6,461)$ (gráficos 4). 

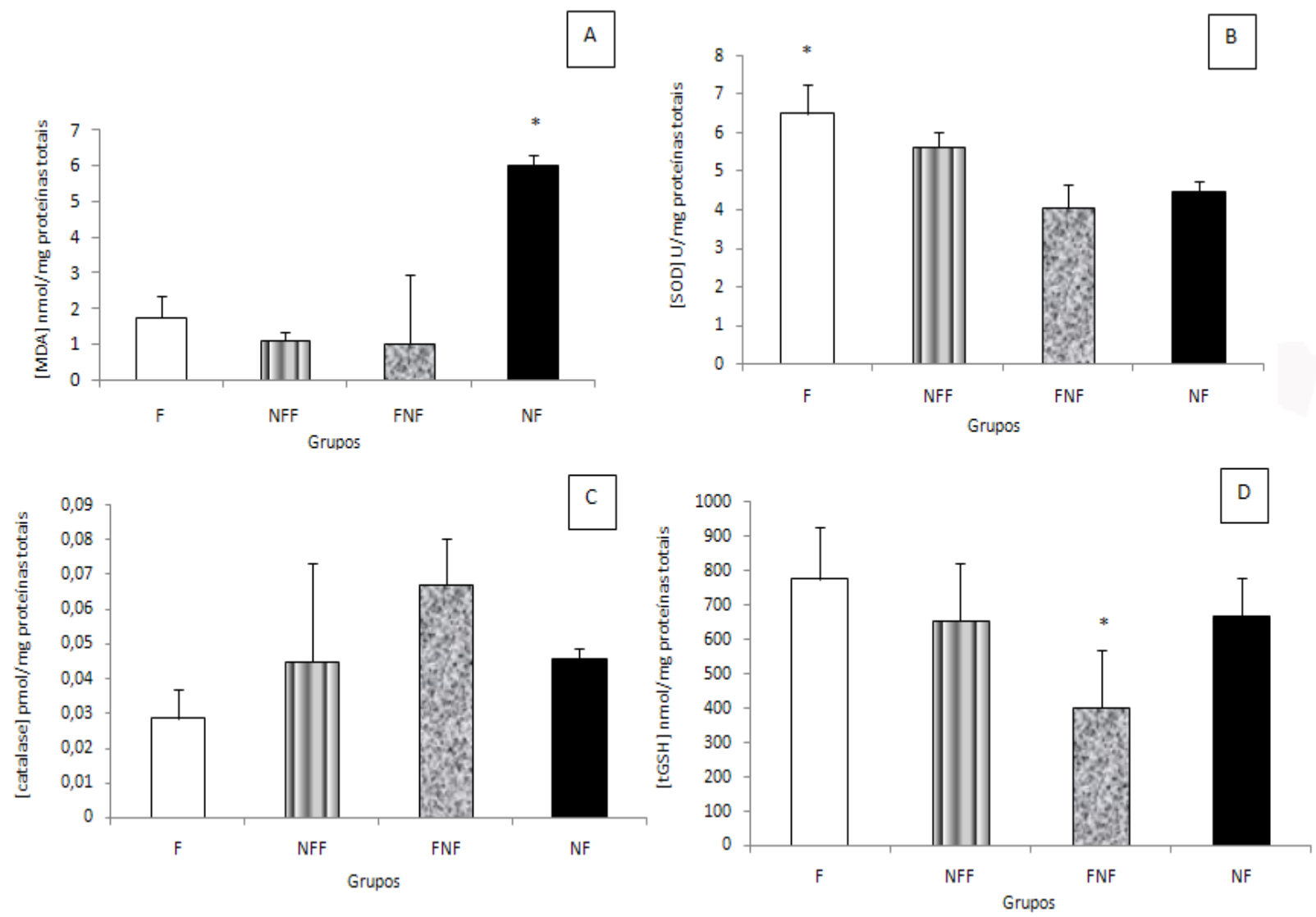

Gráficos 4: Representação gráfica da concentração de MDA, atividades das enzimas SOD e catalase e da concentração de glutationa total no córtex cerebral de ratos adultos expostos ou não à poluição atmosférica a nível ambiental durante a fase intra-uterina e o período de lactação. Grupos experimentais: $F$ (filtrado), NFF (não filtrado/filtrado), FNF (filtrado/não filtrado), NF (não filtrado). Valores expressos como média \pm erro padrão. ANOVA 1 via: A: *diferença significativa quando comparamos o grupo NF aos grupos $\mathrm{F}$, NFF e FNF $(\mathrm{P}=0,007)$; $\mathrm{B}$ : *diferença significativa quando comparamos o grupo $F$ aos grupos $F$, NFF e $F N F(P=0,012)$; $C$ : não houve diferença estatisticamente significativa entre os grupos $(P=0,440)$; $D$ :*diferença significativa quando comparamos o grupo FNF aos grupos $F$, NFF e NF $(P=0,003)$.

Quanto ao hipocampo, a concentração de MDA foi maior no grupo FNF em relação aos demais grupos $\left(P=0,006 ; F_{(3 ; 24)}=5,532\right)$. Não houve diferença estatisticamente significativa no hipocampo entre os animais para as atividades da $\operatorname{SOD}\left(P=0,360 ; F_{(3 ; 27)}=1,122\right)$ e da catalase $\left(P=0,715 ; F_{(3 ; 30)}=0,456\right)$. O grupo FNF 
apresentou uma concentração de GSHt hipocampal menor, quando comparado aos outros grupos $\left(P=0,021 ; F_{(3 ; 27)}=3,890\right)$ (gráficos 5$)$.
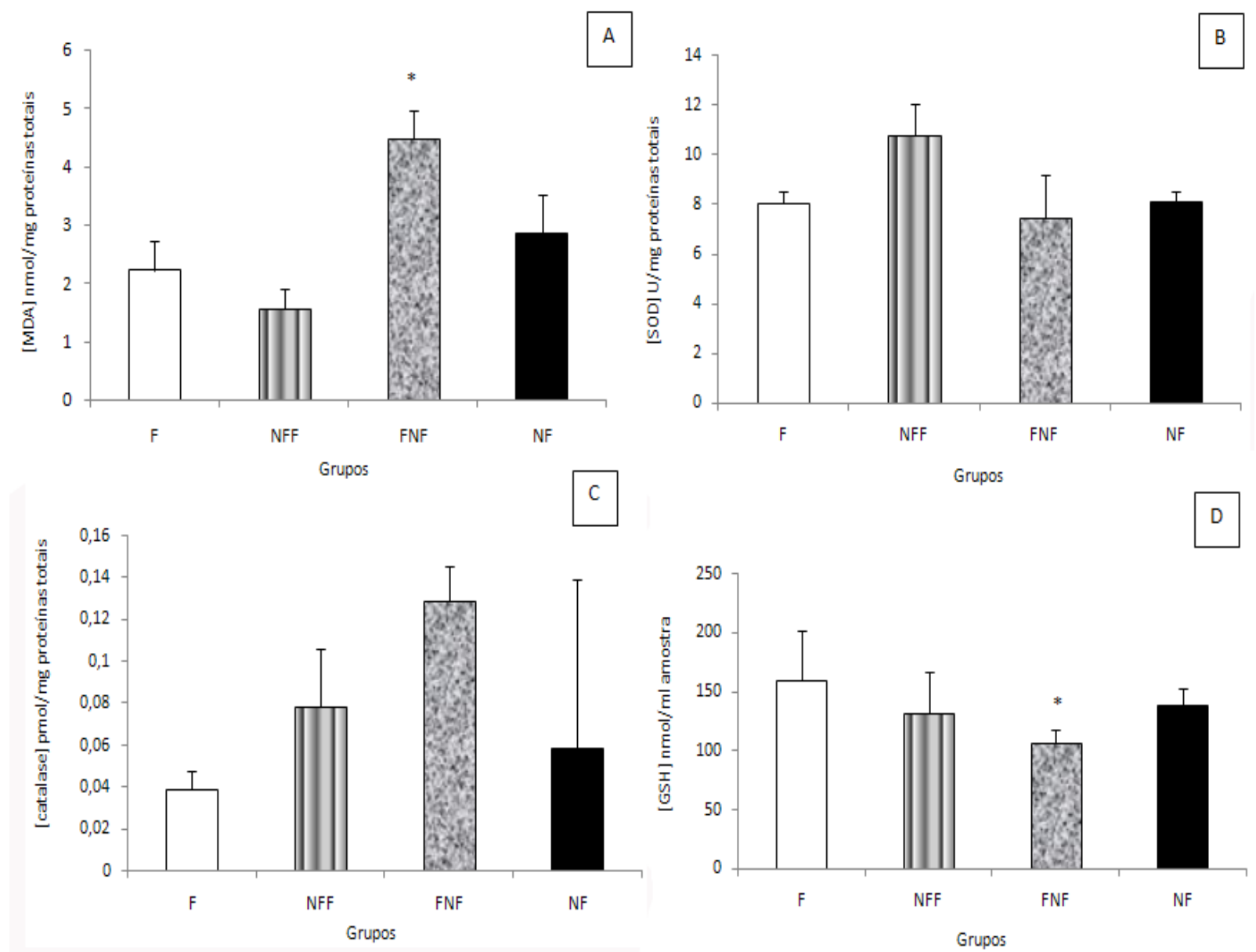

Gráficos 5: Representação gráfica da concentração de MDA, atividades das enzimas SOD e catalase e da concentração de glutationa total no hipocampo cerebral de ratos adultos expostos ou não à poluição atmosférica a nível ambiental durante a fase intra-uterina e o período de lactação. Grupos experimentais: $F$ (filtrado), NFF (não filtrado/filtrado), FNF (filtrado/não filtrado), NF (não filtrado). Valores expressos como média \pm erro padrão. ANOVA 1 via: A: *diferença significativa quando comparamos o grupo FNF aos grupos $F$, NFF e NF $(P=0,006)$; $B$ : não houve diferença estatisticamente significativa entre os grupos $(P=0,360)$; $C$ : não houve diferença estatisticamente significativa entre os grupos $(P=0,715) ; D$ :*diferença significativa quando comparamos o grupo FNF aos grupos $F$, NFF e NF $(P=0,021)$. 
Quando analisamos o estriado, observamos um aumento significativo da concentração de MDA no grupo NF quando comparado aos demais grupos $\left(P=0,010 ; F_{(3 ; 42)}=4,296\right)$. Já o grupo $F N F$ apresentou menor atividade da SOD $\left(P=0,004 ; F_{(3 ; 34)}=5,337\right)$ e maior concentração de GSHt $\left(P=0,006 ; F_{(3 ; 23)}=5,654\right)$ quando comparado aos outros grupos. A atividade da catalase não apresentou diferença estatisticamente significativa entre os grupos $\left(P=0,066 ; F_{(3 ; 36)}=2,641\right)$. 

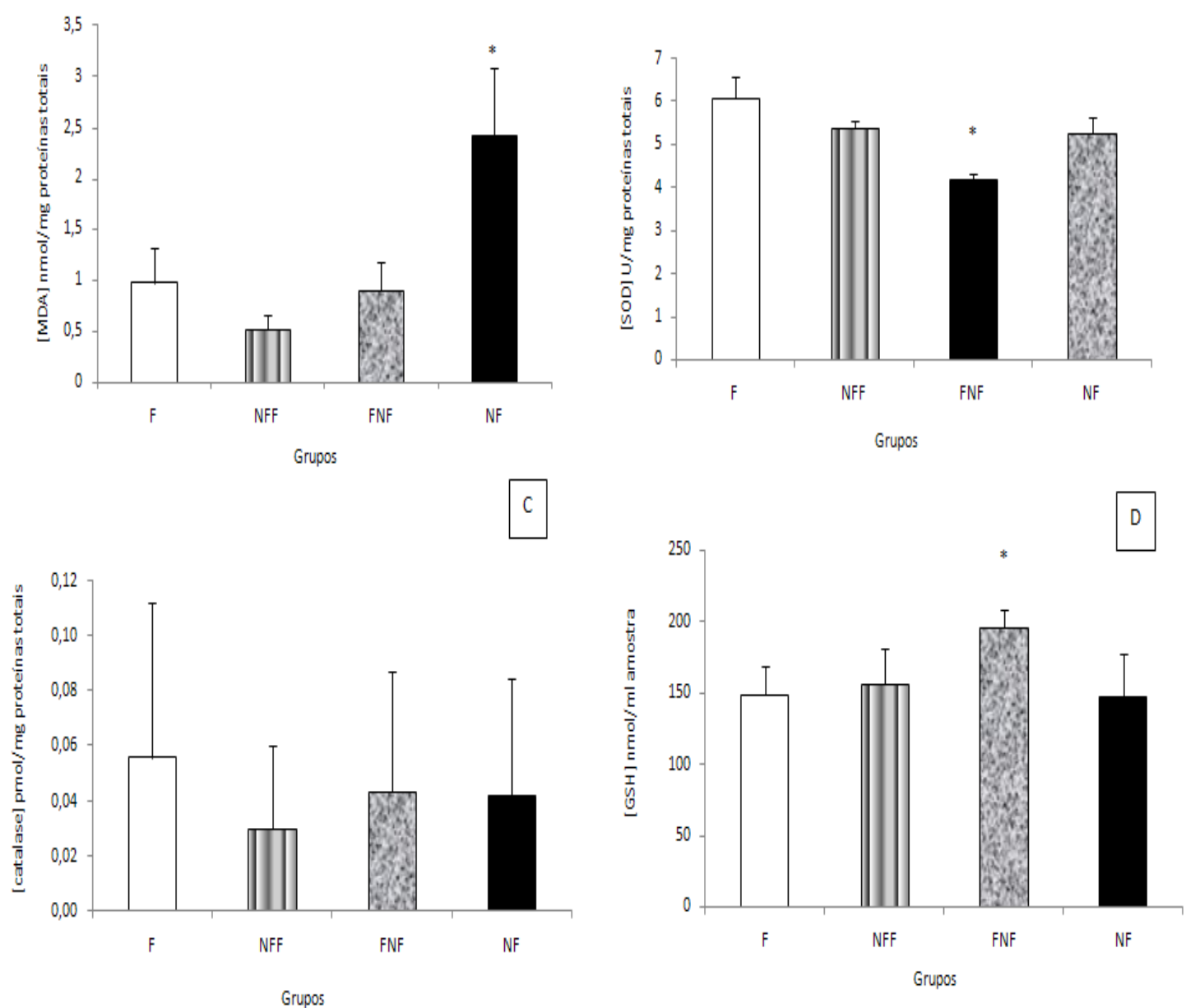

Gráficos 6: Representação gráfica da concentração de MDA, atividades das enzimas SOD e catalase e da concentração de glutationa total no estriado de ratos adultos expostos ou não à poluição atmosférica a nível ambiental durante a fase intra-uterina e o período de lactação. Grupos experimentais: F (filtrado), NFF (não filtrado/filtrado), FNF (filtrado/não filtrado), NF (não filtrado). Valores expressos como média \pm erro padrão. ANOVA 1 via: A: * diferença significativa quando comparamos o grupo NF aos grupos $\mathrm{F}$, NFF e FNF $(\mathrm{P}=0,010) ; \mathrm{B}$ * diferença significativa quando comparamos o grupo FNF aos grupos $F$, NFF e NF $(P=0,004) ; C$ : não houve diferença estatisticamente significativa entre os grupos $(P=0,066) ; D$ :*diferença significativa quando comparamos o grupo FNF aos grupos $F$, NFF e NF $(P=0,006)$. 
5.4 Determinação da concentração de elementos traço tóxicos e essenciais no sangue total

Conforme descrito na tabela 3 , verificamos um aumento estatisticamente significativo na concentração sanguínea de cádmio dos animais pertencentes aos grupos FNF e NF quando comparados aos outros dois grupos $\left(P=0,005 ; F_{(3 ;}\right.$ 23) $=5,870$ ). Em relação ao antimônio, observamos uma diminuição de sua concentração no sangue dos animais do grupo $F\left(P=0,004 ; F_{(3 ; 23)}=6,091\right)$. Não foi observada diferença significativa na concentração de chumbo considerando-se os quatro grupos experimentais $\left(P=0,104 ; F_{(3 ; 23)}=0,823\right)$. 
Tabela 3: Determinação das concentrações de elementos traço tóxicos no sangue total de ratos adultos expostos ou não à poluição atmosférica ambiental durante a fase intra-uterina e o período de lactação.

\begin{tabular}{|c|c|c|c|}
\hline Elementos traço tóxicos & $\begin{array}{l}\text { Grupos } \\
\text { experimentais }\end{array}$ & Concentração $(\mu \mathrm{g} / \mathrm{L})$ & $\mathrm{P}$ \\
\hline $\mathrm{Cd}$ & $\begin{array}{l}\text { F } \\
\text { NFF } \\
\text { FNF } \\
\text { NF }\end{array}$ & $\begin{array}{l}0,133 \pm 0,0516 \\
0,217 \pm 0,0983 \\
0,283 \pm 0,0659^{*} \\
0,293 \pm 0,0750 *\end{array}$ & $\begin{array}{c}0,002 \\
\mathrm{~F}_{(3 ; 23)}=5,870\end{array}$ \\
\hline $\mathrm{Pb}$ & $\begin{array}{l}\text { F } \\
\text { NFF } \\
\text { FNF } \\
\text { NF }\end{array}$ & $\begin{array}{l}1,983 \pm 1,113 \\
2,650 \pm 2,214 \\
2,650 \pm 1,290 \\
3,817 \pm 3,022\end{array}$ & $\begin{array}{c}0,104 \\
F_{(3 ; 23)}=6,091\end{array}$ \\
\hline $\mathrm{Sb}$ & $\begin{array}{l}\text { F } \\
\text { NFF } \\
\text { FNF } \\
\text { NF }\end{array}$ & $\begin{array}{l}0,868 \pm 0,271^{* *} \\
1,633 \pm 0,388 \\
1,587 \pm 0,389 \\
1,667 \pm 0,446\end{array}$ & $\begin{array}{c}0,004 \\
F_{(3 ; 23)}=0,823\end{array}$ \\
\hline
\end{tabular}

Os valores estão expressos como média \pm DP (desvio padrão). ANOVA 1 via para comparação entre os quatro grupos, seguida pelo teste de Student Newman Keuls: [Cd]: *diferença significativa quando comparamos o grupo $\mathrm{F}$ aos grupos FNF e NF $(P=0,002) ;[P b]$ : não houve diferença estatisticamente significativa entre os grupos; [Sb]: ** diferença significativa quando comparamos o grupo $\mathrm{F}$ aos grupos NFF, FNF e $N F(P=0,004)$. Grupos experimentais: $F$ (filtrado), NFF (não filtrado/filtrado), FNF (filtrado/não filtrado), NF (não filtrado). $\mathrm{Cd}=$ cádmio, $\mathrm{Pb}=$ chumbo e $\mathrm{Sb}=$ antimônio. 
Tabela 4: Determinação das concentrações de elementos traço essenciais no sangue total de ratos expostos ou não à poluição atmosférica ambiental durante a fase intra-uterina e o período de lactação.

\begin{tabular}{|c|c|c|c|}
\hline Elementos traço essenciais & $\begin{array}{c}\text { Grupos } \\
\text { experimentais }\end{array}$ & Concentração $(\mu \mathrm{g} / \mathrm{L})$ & $P$ \\
\hline $\mathrm{Cu}$ & $\begin{array}{l}\text { F } \\
\text { NFF } \\
\text { FNF } \\
\text { NF }\end{array}$ & $\begin{array}{l}927,833 \pm 145,074 \\
1148,500 \pm 89,229^{*} \\
908,667 \pm 34,500 \\
1002,833 \pm 90,418\end{array}$ & $\begin{array}{c}0,002 \\
F_{(3 ; 23]}=7,416\end{array}$ \\
\hline $\mathrm{Mn}$ & $\begin{array}{l}\text { F } \\
\text { NFF } \\
\text { FNF } \\
\text { NF }\end{array}$ & $\begin{array}{l}13,633 \pm 4,878 \\
15,500 \pm 5,244 \\
9,767 \pm 5,148 \\
9,867 \pm 2,267\end{array}$ & $\begin{array}{c}0,104 \\
F_{(3 ; 23)}=2,345\end{array}$ \\
\hline $\mathrm{Se}$ & $\begin{array}{l}\text { F } \\
\text { NFF } \\
\text { FNF } \\
\text { NF }\end{array}$ & $\begin{array}{l}407,333 \pm 74,712 \\
535,333 \pm 17,317^{*} \\
404,333 \pm 40,471 \\
449,167 \pm 61,655\end{array}$ & $\begin{array}{c}0,001 \\
F_{(3 ; 23]}=7,904\end{array}$ \\
\hline $\mathrm{Zn}$ & $\begin{array}{l}\text { F } \\
\text { NFF } \\
\text { FNF } \\
\text { NF }\end{array}$ & $\begin{array}{l}5674,833 \pm 720,524 \\
7145,000 \pm 268,274^{*} \\
5958,500 \pm 478,797 \\
6274,500 \pm 664,331\end{array}$ & $\begin{array}{c}0,001 \\
F_{(3 ; 23)}=7,715\end{array}$ \\
\hline
\end{tabular}

Valores estão expressos como média \pm DP (desvio padrão). ANOVA 1 via para comparação entre os quatro grupos, seguida pelo teste de Student Newman Keuls: [Cu]: *diferença significativa quando comparamos o grupo NFF aos grupos F, FNF e $\mathrm{NF}$; [Mn]: *diferença significativa quando comparamos o grupo NFF aos grupos $\mathrm{F}$, FNF e NF; [Se]: *diferença significativa quando comparamos o grupo NFF aos grupos F, FNF e NF; [Zn]: *diferença significativa quando comparamos o grupo NFF aos grupos F, FNF e NF. Grupos experimentais: F (filtrado), NFF (não filtrado/filtrado), FNF (filtrado/não filtrado), NF (não filtrado). $\mathrm{Cu}=$ cobre, $\mathrm{Mn}=$ manganês, Se= selênio e $\mathrm{Zn}=$ zinco. 


\subsection{Análises histológicas por técnicas estereológicas}

\subsubsection{Volume total das estruturas encefálicas}

Os volumes totais das estruturas encefálicas (córtex, hipocampo e estriado) estão representados na tabela 5. Podemos observar que não houve diferença significativa nos volumes das estruturas córtex $\left(P=0,310 ; F_{(3 ; 23)}=1,274\right)$, hipocampo $(P=0,275 ; \quad F(3 ; 19)=1,416)$ e estriado $\left(P=0,288 ; F_{(3 ; 19)}=1,369\right)$ quando comparamos os quatro grupos experimentais: F, NFF, FNF e NF. 
Tabela 5: Valores dos volumes das estruturas encefálicas (córtex, hipocampo e estriado) dos ratos adultos expostos ou não à poluição atmosférica a nível ambiental durante a fase pré-natal e o período de lactação.

\begin{tabular}{c|l|c|c}
\hline Estruturas & Grupos & Volume $\left(\mathrm{mm}^{3}\right)$ & $P$ \\
\hline Córtex & F & $378,650 \pm 48,642$ & 0,310 \\
& NFF & $362,570 \pm 31,711$ & \\
& FNF & $388,981 \pm 7,459$ & $F_{(3 ; 23)}=1,274$ \\
& NF & $420,799 \pm 90,911$ & \\
\hline Hipocampo & F & $71,570 \pm 20,266$ & 0,275 \\
& NFF & $57,851 \pm 19,294$ & $F_{(3 ; 19)}=1,416$ \\
& FNF & $79,074 \pm 4,841$ & \\
& NF & $65,950 \pm 18,120$ & \\
\hline Estriado & F & $71,273 \pm 14,151$ & 0,288 \\
& NFF & $57,025 \pm 16,467$ & $F_{(3 ; 19)}=1,369$ \\
& FNF & $62,529 \pm 13,976$ & \\
& NF & $76,860 \pm 16,467$ & \\
\hline
\end{tabular}

Valores expressos em média DP (desvio padrão). ANOVA 1 via para comparação entre os quatro grupos experimentais: $F$ (filtrado), NFF (não filtrado/filtrado), FNF (filtrado/não filtrado), NF (não filtrado). Não houve diferença significativa entre os grupos. Densidade específica do encéfalo: 1,210. 


\subsubsection{Contagem de neurônios e neuroglia}

\subsubsection{Córtex}

Na figura abaixo (figura 23), observamos foto de corte do córtex cerebral de rato. No gráfico 7, observamos que o grupo NF apresentou maior número de neurônios $\left(P=0,018 ; F_{(3 ; 22)}=4,276\right)$, bem como de neuroglia $\left(P=0,002 ; F_{(3 ; 22)}=7,508\right)$ quando comparado aos grupos F, NFF e FNF.

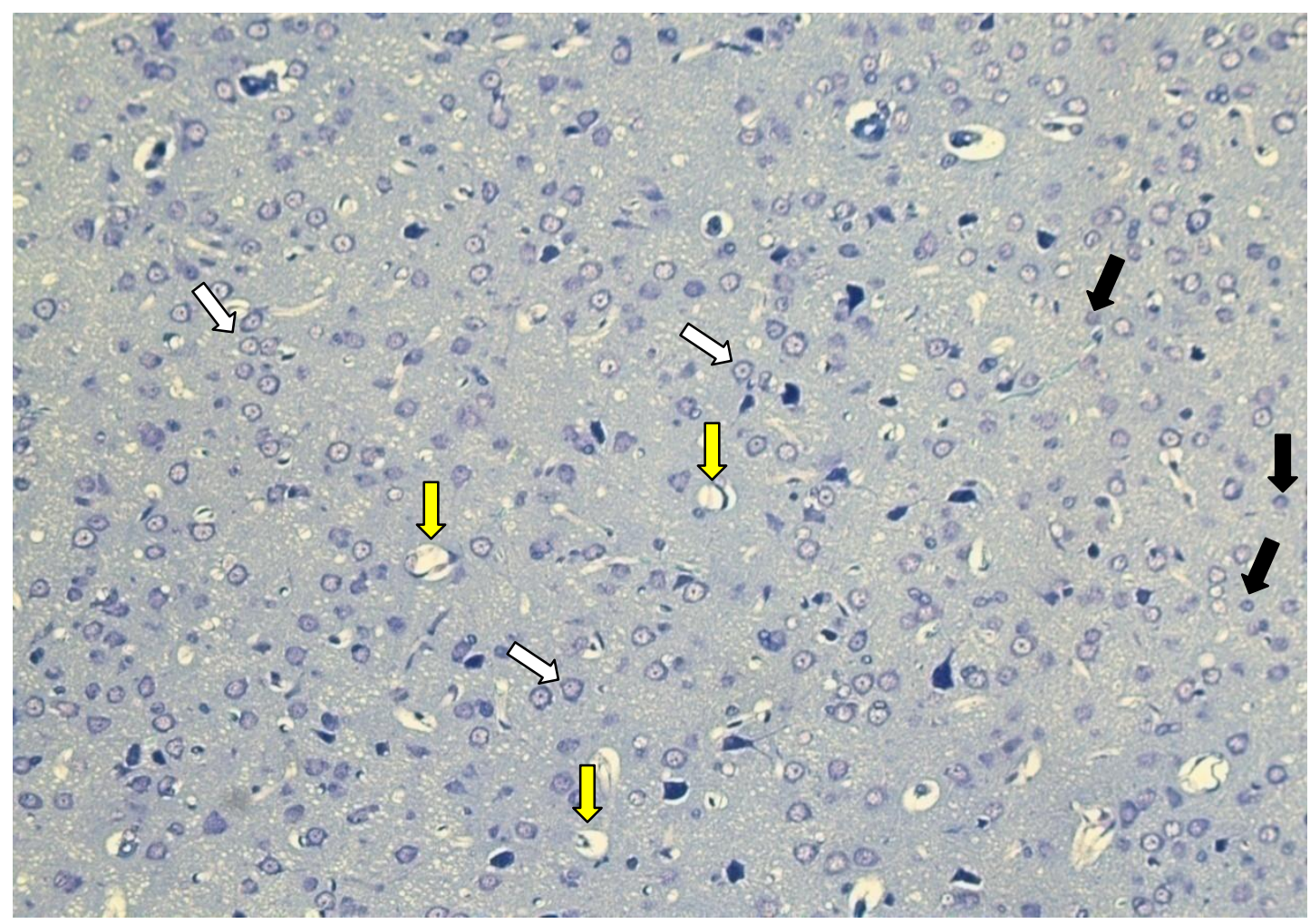

Figura 23: Fotografia ilustrativa de corte de córtex cerebral de rato exposto à poluição atmosférica ambiental após o período de desmame até 150 dias de vida (grupo FNF) corado com azul de toluidina, $5 \mu \mathrm{m}$. Setas brancas: neurônios corticais. Setas pretas: células da glia. Setas amarelas: vasos. 


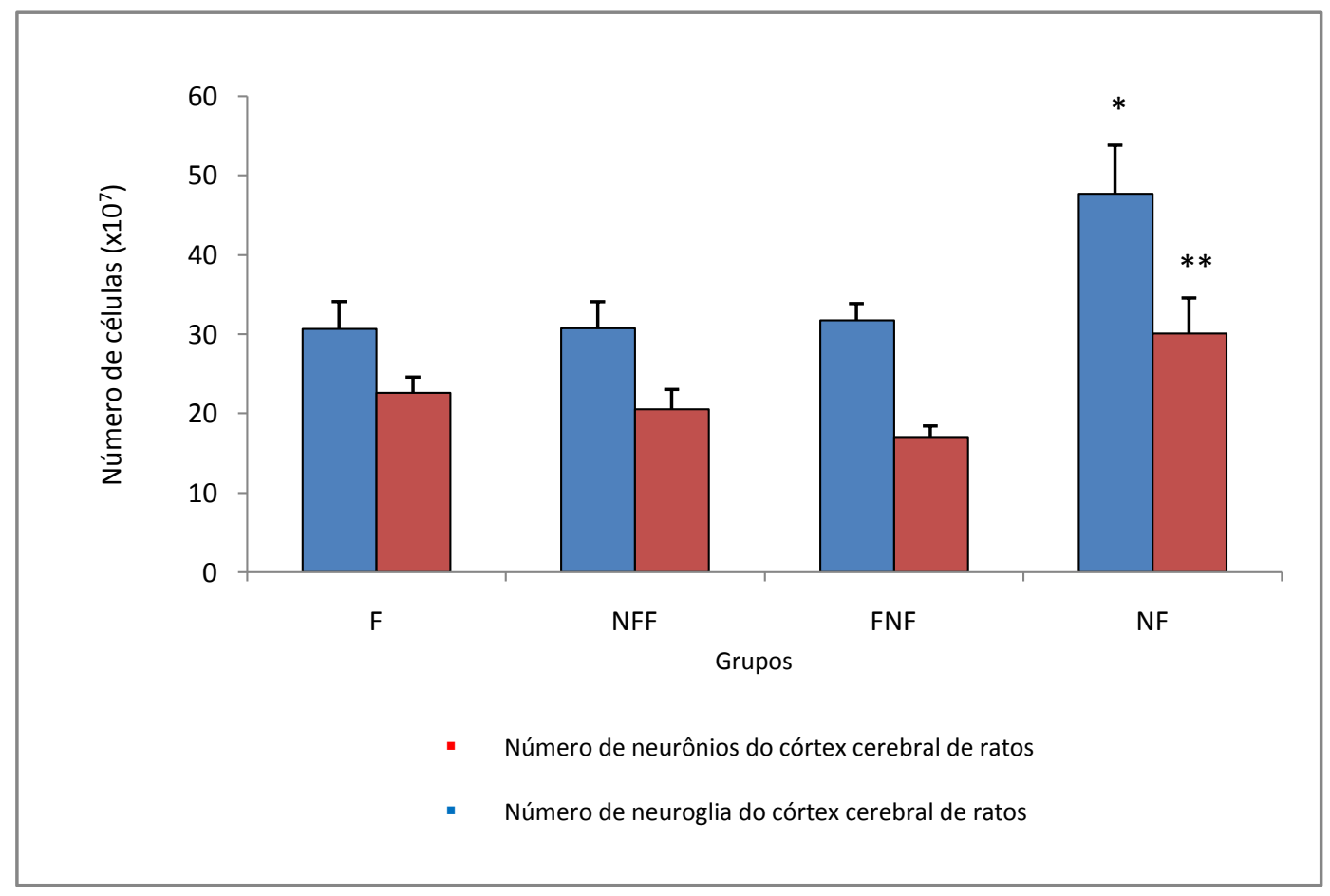

Gráfico 7: Representação gráfica do número de células (neurônios e neuroglia) do córtex cerebral de ratos adultos expostos ou não à poluição atmosférica a nível ambiental na fase pré-uterina e durante o período de lactação. Grupos experimentais: $F$ (filtrado), NFF (não filtrado/filtrado), FNF (filtrado/não filtrado), NF (não filtrado). Resultados expressos como média $\left(\times 10^{7}\right) \pm S E M\left(\times 10^{7}\right)$ (erro padrão). ANOVA 1 via: * diferença significativa para o número de neurônios quando comparamos o grupo NF aos grupos $\mathrm{F}$, NFF e FNF $(P=0,018)$. **diferença significativa para o número de neuroglia quando comparamos o grupo NF aos grupos $F$, NFF e FNF $(P=0,002)$. 


\subsubsection{Hipocampo}

Na figura abaixo (figura 24), observamos foto de corte de hipocampo cerebral do rato. Em relação ao número de neurônios, observamos no gráfico 8 que o grupos NF apresentaram maior número de células neuronais $(P=0,021$; $\left.F_{(3 ; 23)}=4,066\right)$ quando comparados ao grupo $F$ e NFF e FNF. Quanto ao número de neuroglia (gráfico 8), não foi observado nenhuma diferença significativa entre os grupos experimentais $\left(P=0,150 ; F_{(3 ; 23)}=1,975\right)$.

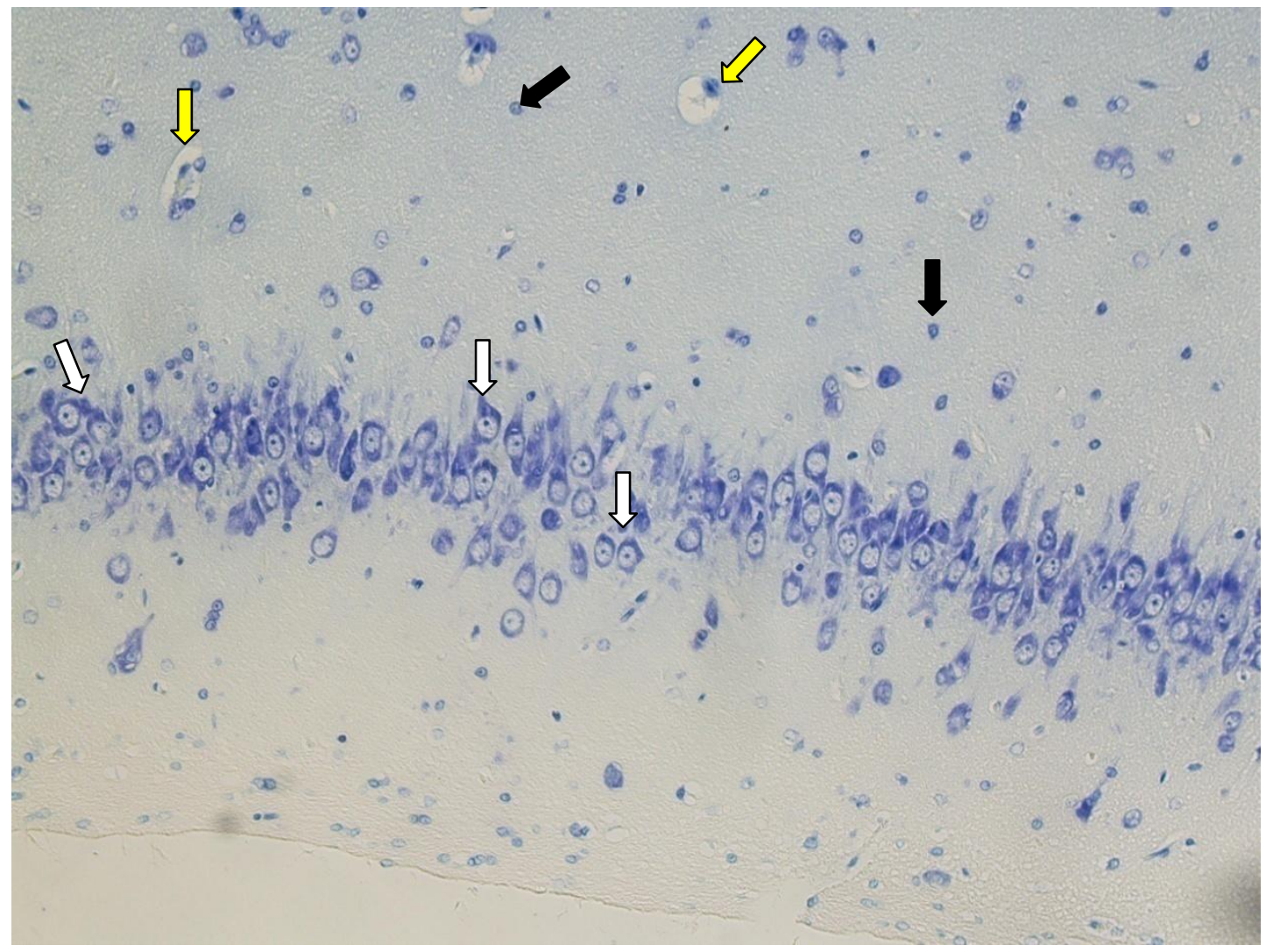

Figura 24: Fotografia ilustrativa de hipocampo de rato exposto à plouição atmosférica a nível ambiental desde a vida intra-uterina até 150 dias de vida (grupo NF) corado com azul de toluidina, $5 \mu \mathrm{m}$. Setas brancas: neurônios hipocampais. Setas pretas: células da glia. Setas amarelas: vasos. 


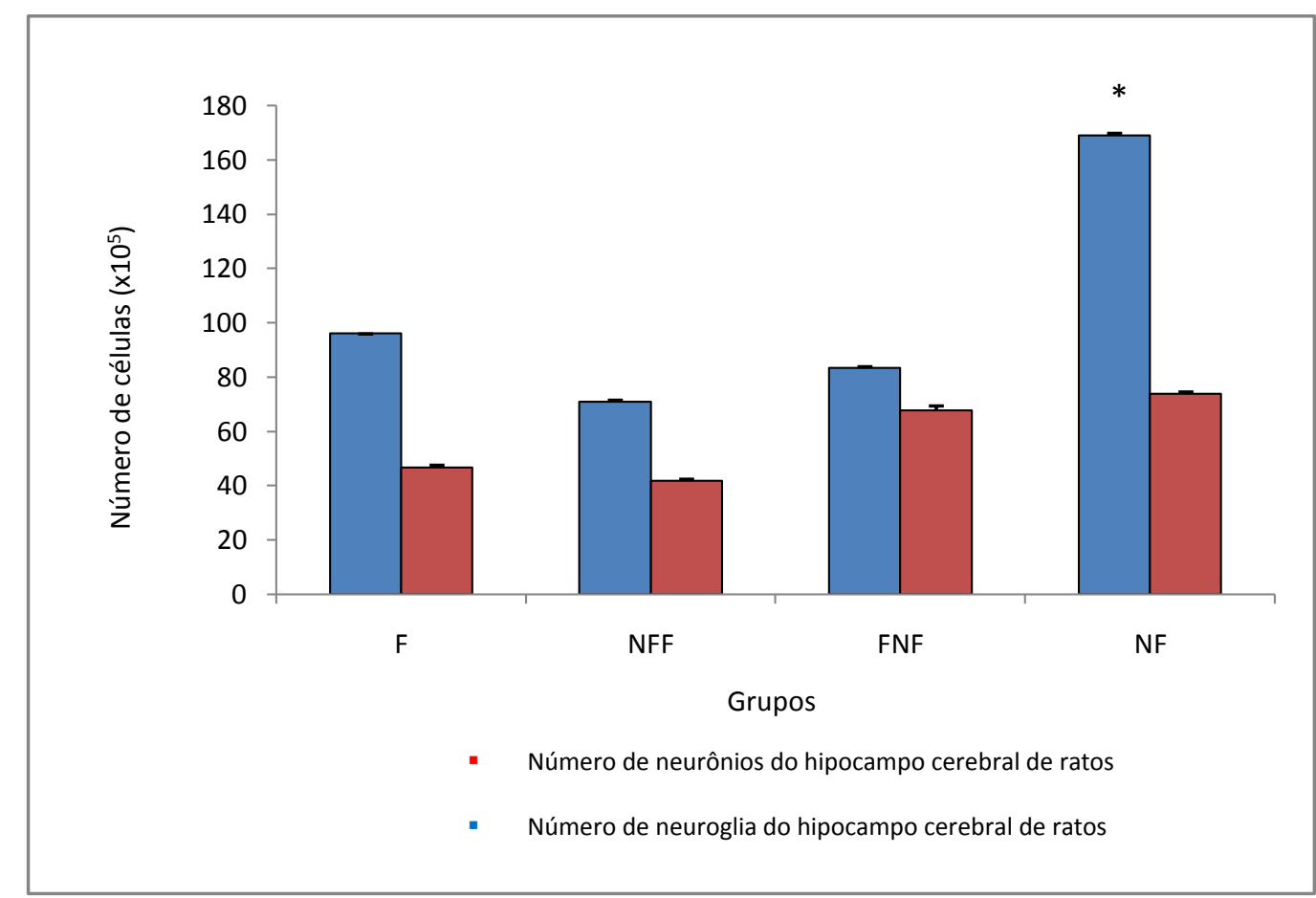

Gráfico 8: Representação gráfica do número de células (neurônios e neuroglia) do hipocampo cerebral de ratos adultos expostos ou não à poluição atmosférica a nível ambiental na fase pré-uterina e durante o período de lactação. Grupos experimentais: $F$ (filtrado), NFF (não filtrado/filtrado), FNF (filtrado/não filtrado), NF (não filtrado). Resultados expressos como média $\left(\times 10^{5}\right) \pm S E M\left(\times 10^{5}\right)$ (erro padrão). ANOVA 1 via: * diferença significativa para o número de neurônios quando comparamos o grupo NF aos grupos $F$, NFF e FNF $(P=0,021)$. 


\subsubsection{Estriado}

$\mathrm{Na}$ figura abaixo (figura 25), observamos corte de estriado cerebral do rato.

No gráfico 9, observamos que não houve diferença significativa entre grupos F, NFF,

FNF e NF quanto ao número de neurônios $\left(P=0,102 ; F_{(3 ; 23)}=2,362\right)$ e em relação ao número de neuroglia $\left(P=0,287 ; F_{(3 ; 23)}=1,347\right)$.

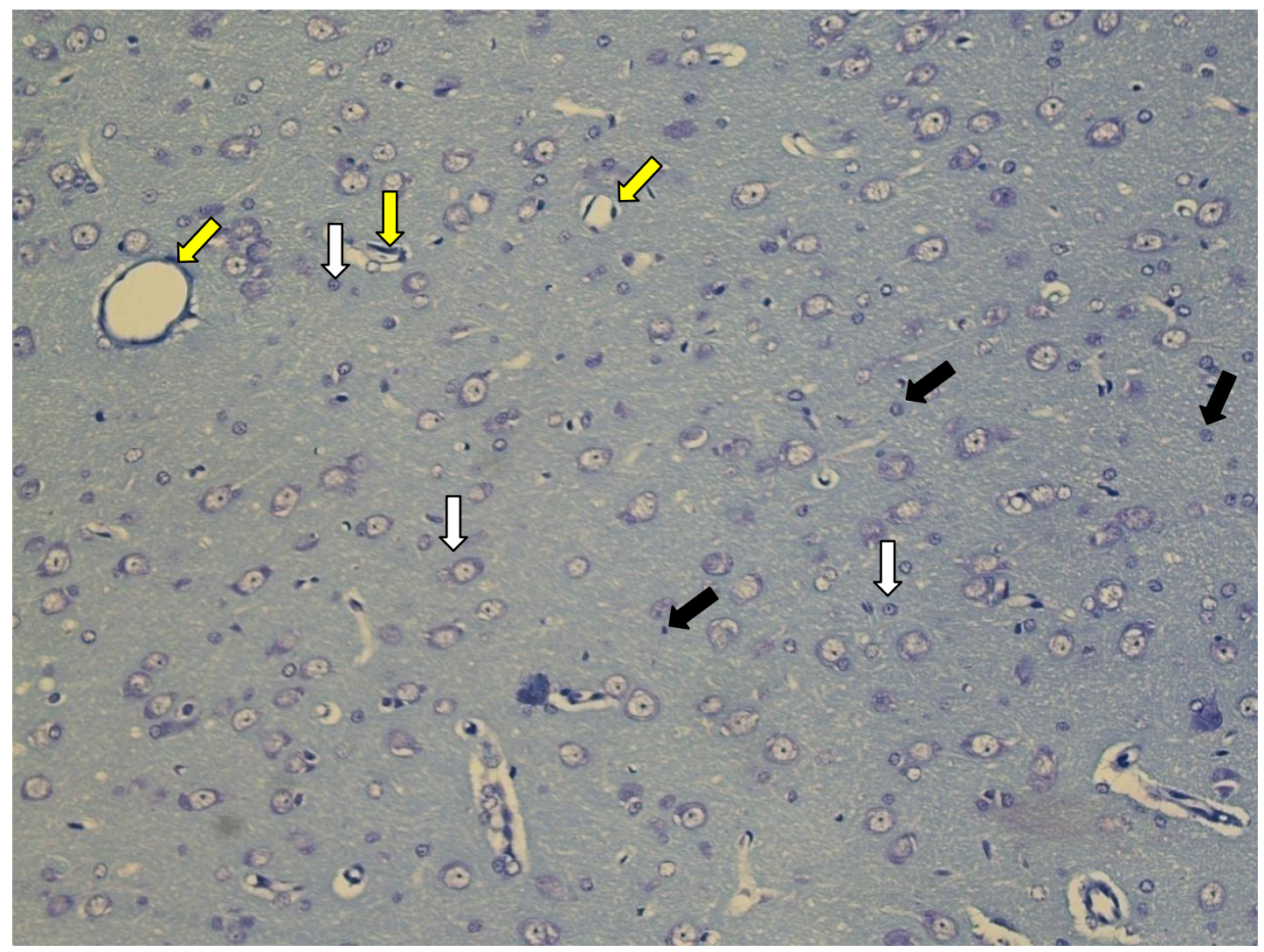

Figura 25: Fotografia ilustrativa de estriado de rato exposto à poluição atmosférica ambiental após o período de desmame até 150 dias de vida (grupo FNF) corado com azul de toluidina, $5 \mu \mathrm{m}$. Setas brancas: neurônios estriatais. Setas pretas: células da glia. Setas amarelas: vasos. 


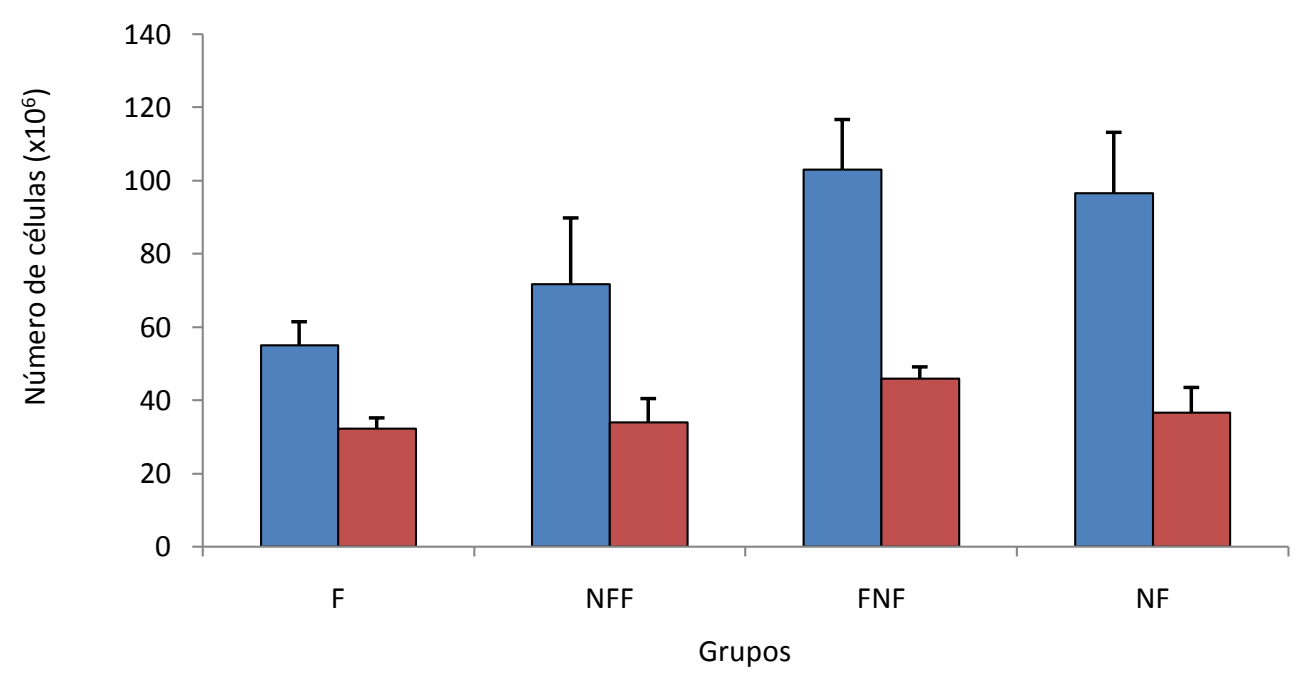

- Número de neurônios do hipocampo cerebral de ratos

- Número de neuroglia do hipocampo cerebral de ratos

Gráfico 9: Representação gráfica do número de células (neurônios e neuroglia) do estriado cerebral de ratos adultos expostos ou não à poluição atmosférica a nível ambiental na fase pré-uterina e durante o período de lactação. Grupos experimentais: $F$ (filtrado), NFF (não filtrado/filtrado), FNF (filtrado/não filtrado), NF (não filtrado). Resultados expressos como média $\left(\times 10^{6}\right) \pm S E M\left(\times 10^{6}\right)$ (erro padrão). ANOVA 1 via: não houve diferença significativa para o número de neurônios $(P=0,102)$ e de neuroglia $(P=0,287)$ quando comparamos o grupo NF aos grupos $F$, NFF e FNF. 


\section{DISCUSSÃO}

Estudos experimentais têm demonstrado que a exposição à poluição ambiental mesmo durante o período pré-natal é capaz de comprometer o desenvolvimento dos indivíduos expostos. Veras e cols. (2008; 2009) evidenciaram redução no peso de nascimento de camundongos cujas mães foram expostas a ambiente poluído na cidade de São Paulo. Lichtenfels e cols. (2007) encontraram um predomínio de fêmeas nas proles nascidas nessa mesma cidade. Entretanto, no presente estudo, não foram observadas diferenças estatisticamente significativas quanto ao peso médio de cada filhote, bem como da ninhada ao nascer e no sétimo dia do período pós-natal no ambiente poluído na cidade de Porto Alegre (POA) em relação aos animais nascidos em ambiente limpo. Não houve, também, diferença no número de machos e fêmeas nascidos em ambiente poluído na cidade de Porto Alegre. Os animais expostos durante a fase intra-uterina até o final do período de lactação nas câmaras cujo ar era filtrado e não filtrado, respectivamente, em Porto Alegre, não apresentaram, também, problemas quanto ao seu desenvolvimento de acordo com os parâmetros analisados, ou seja, tempo necessário para a abertura dos olhos e para o aparecimento da primeira penugem. Nossos resultados, portanto, estão em discordância com os dados descritos na literatura. Na tentativa de explicarmos tais diferenças devemos salientar que a concentração do $\mathrm{MP}_{2,5}$ difere entre as duas cidades, Porto Alegre e São Paulo. As concentrações médias diárias anuais de $\mathrm{MP}_{2,5}$ de Porto Alegre e São Paulo foram, respectivamente, de 28,1 
$\mu \mathrm{g} / \mathrm{m}^{3}$ e $16,3 \mu \mathrm{g} / \mathrm{m}^{3}$, no período de junho de 2007 a agosto de 2008 (periodo em que nosso estudo foi realizado). Sabe-se que a concentração dos poluentes atmosféricos sofre influência de parâmetros metereológicos, onde um sistema de alta pressão normalmente está associado a céu claro e ventos fracos, condições favoráveis a dispersão de poluentes; sistema de baixa pressão, aumento da umidade relativa, da velocidade dos ventos gera queda nos valores das concentrações. A cidade de Porto Alegre apresentou médias de temperatura mais baixas que São Paulo durante o período de junho de 2007 a agosto de 2008, sendo que em POA a temperatura oscilou entre 10 e $25^{\circ} \mathrm{C}$ e, em SP, entre 20 e $25^{\circ} \mathrm{C}$. Quanto à velocidade dos ventos, esta foi menor em SP e abrangeu um intervalo entre 0,5 a 4,0 m/s em relação a Porto Alegre $-0,2$ a 5,0 m/s. A umidade relativa foi maior em Porto Alegre durante o período analisado (Laboratório de Poluição Atmosférica Experimental, Laboratório de Análises de Processos Atmosféricos, 2009). Portanto, as diferenças climáticas influenciaram na concentração do $\mathrm{MP}_{2,5} \mathrm{e}$ podem explicar, em parte, os resultados obtidos em nosso estudo.

Além da concentração do $\mathrm{MP}_{2,5}$ diferir entre as duas cidades, a composição química das partículas também difere, de forma que na cidade de SP o material particulado $\left(\mathrm{MP}_{2,5}\right)$ é composto por elevadas concentrações de elementos traço tóxicos - $\mathrm{Al}, \mathrm{Pb}, \mathrm{V}, \mathrm{Ni}$ e outros (tabela 6) - além de nitratos e sulfatos em relação às quantidades encontradas nas partículas coletadas em Porto Alegre (Laboratório de Poluição Atmosférica Experimental, Laboratório de Análises de Processos Atmosféricos, 2009). Portanto, a diferença entre os nossos resultados e os dados da literatura poderia ser também explicada, pela composição química distinta do MP 
entre as duas cidades, a qual também se relaciona com a localização geográfica, condições metereológicas (velocidade dos ventos, chuvas, temperatura, pressão, umidade relativa) e clima de cada uma das cidades estudadas.

Logo, dependendo da concentração e da composição química do MP teremos determinado tipo de resposta, seja em parâmetros como número total de filhotes, de machos, de fêmeas, tempo para a abertura dos olhos e para o aparecimento da primeira penugem, peso médio de cada filhote, da ninhada, bem como, possivelmente, em parâmetros bioquímicos, hematológicos e histológicos. 
Tabela 6: Comparação entre as concentrações médias de cada elemento traço obtidas através da técnica de fluorescência de raios $X$ (FRX) para as amostras coletadas de $\mathrm{MP}_{2.5}$ em filtros de policarbonato provenientes das cidades de Porto Alegre (POA) e São Paulo (SP).

\begin{tabular}{c|c|c}
\hline Elementos traço & POA: $\mathrm{MP}_{2,5}\left(\mathrm{ng} / \mathrm{m}^{3}\right.$ ar $)$ & $\mathrm{SP}: \mathrm{MP}_{2,5}\left(\mathrm{ng} / \mathrm{m}^{3} \mathrm{ar}\right)$ \\
\hline $\mathrm{Al}$ & $39,9 \pm 33,0$ & $67,3 \pm 66,2$ \\
\hline $\mathrm{V}$ & $0,7 \pm 0,8$ & $1,8 \pm 1,4$ \\
\hline $\mathrm{Cr}$ & $1,0 \pm 2,2$ & $1,7 \pm 1,7$ \\
\hline $\mathrm{Mn}$ & $2,8 \pm 3,3$ & $7,1 \pm 4,6$ \\
\hline $\mathrm{Ni}$ & $0,7 \pm 1,6$ & $4,5 \pm 6,5$ \\
\hline $\mathrm{Cu}$ & $2,6 \pm 4,0$ & $35,6 \pm 52,8$ \\
\hline $\mathrm{Zn}$ & $14,9 \pm 19,5$ & $97,6 \pm 93,3$ \\
\hline $\mathrm{Se}$ & $1,4 \pm 1,1$ & $5,7 \pm 7,8$ \\
\hline $\mathrm{Br}$ & $2,4 \pm 2,4$ & $12,8 \pm 18,4$ \\
\hline $\mathrm{Pb}$ & $5,8 \pm 5,5$ & $38,2 \pm 30,3$ \\
\hline
\end{tabular}

Valores expressos em média \pm desvio padrão (DP). $\mathrm{N}=134$ (número de amostras submetidas à análise de FRX) (Laboratório de Poluição Atmosférica Experimental, Laboratório de Análise de Processos Atmosféricos, 2009). 
Derelanko e Hollinger (2002) mostraram que os testes comportamentais realizados em roedores apresentam validade de face já que humanos e ratos apresentam parâmetros cognitivos e motores semelhantes. Controle motor, habituação, memória de longa e curta duração são parâmetros úteis para avaliação do comportamento animal permitindo que os resultados sejam inferidos para humanos.

Os animais do grupo NF apresentaram diminuição no índice de discriminação no teste de reconhecimento espontâneo de objetos. A diminuição do índice nesse grupo que foi exposto aos poluentes durante toda a vida traduz comprometimento da memória discriminativa de curta duração. Esse índice foi semelhante ao controle nos grupos NFF e FNF, que foram trocados de ambiente após o $21^{\circ}$ dia do período pós-natal. Assim, é possível que a exposição dos animais ao MP durante toda a vida possa sensibilizar o SNC ao dano oxidativo de forma semelhante ao que ocorre com as células do miocárdio de camundongos nascidos e mantidos em câmara de ar poluído (Damaceno-Rodrigues e cols., 2008). Entretanto, observamos o efeito oposto nos parâmetros de memória de habituação. Animais incapazes de se beneficiar das exposições repetidas ao ambiente de testagem são considerados deficitários em termos de memória procedural de habituação (Collier e Routtemberg, 1984). O índice de habituação ao teste, considerado como a redução do tempo de exploração total dos objetos na sessão de teste comparativamente à sessão de treino, foi maior no grupo nascido e mantido em câmara poluída (NF) e naquele exposto à poluição após o $21^{\circ}$ dia do período pósnatal (FNF). Esses dados sugerem que a exposição ao MP na primeira infância até a 
idade adulta possa desencadear mecanismos potencializadores da capacidade de adaptação a novas situações. Zanchi e cols. (2010) corroboraram nossos achados, pois demonstraram que animais adultos expostos ao ROFA (residual oil fly ash) durante 30 dias não apresentaram comprometimento da habituação ao campo aberto.

Embora muitas formas de memória pareçam ser amplamente distribuídas, é certo que as memórias diferem nos mecanismos e locais de processamento e consolidação e nos sistemas neuronais que fazem a sua mediação. A integridade do hipocampo, por exemplo, não é necessária para o julgamento da familiaridade (Aggleton e col, 1986; Ennaceur e Aggleton, 1997). Por outro lado, esta estrutura parece estar envolvida na habituação das respostas exploratórias a novos ambientes (Wolfman e col, 1991). Os nossos achados demonstram claramente que a memória discriminativa declarativa estabelecida e a memória procedural de habituação ao paradigma são distintamente sensíveis à poluição ambiental, da mesma forma que o são as diferentes regiões do cérebro examinadas.

Os resultados obtidos no teste do labirinto de Morris reforçam a idéia de que os diferentes tipos de memória não são comprometidos de forma uniforme pelo dano oxidativo. Este teste foi desenvolvido com o intuito de avaliar a memória espacial (hipocampal) em ratos (Squire e Kendal, 2003). Apesar do aumento de lipoperoxidação nos grupos FNF e NF, não observamos comprometimento do desempenho dos animais destes grupos durante o teste do labirinto de Morris modificado. Nossos dados corroboram outros estudos que demonstraram que o 
hipocampo de camundongos, embora sob influência de lipoperoxidação e estresse oxidativo induzido pela exposição às nanopartículas resultantes da queima do diesel, manteve a sua capacidade funcional, pois esses animais não tiveram dificuldades em encontrar a plataforma no labirinto de Morris (Win-Shwe e cols, 2008).

Estudos preliminares feitos em nosso laboratório demonstraram que ratos adultos expostos ao ROFA (residual oil fly ash) apresentaram aumento na lipoperoxidação no estriado e cerebelo, bem como diminuição na atividade motora no teste do campo aberto (Zanchi e cols., 2008). Em estudo posterior, como já citado anteriormente, o mesmo grupo de autores verificou que a instilação de ROFA não altera a capacidade de habituação de ratos (Zanchi e cols., 2010). Contudo, não havíamos estudado se a exposição de animais a poluição atmosférica a nível ambiental em Porto Alegre desde a fase intra-uterina até a idade adulta alteraria a sua capacidade mnemônica e se o mecanismo envolvido era dependente ou não de oxidantes. Outra questão que precisava ser investigada era se a troca de um ambiente poluído para um ambiente cujo ar era filtrado reverteria o dano oxidativo causado no encéfalo, bem como a perda da capacidade de memorização dos animais. Para tal, foi utilizado o modelo das câmaras de exposição de animais à poluição atmosférica a nível ambiental em Porto Alegre com o objetivo de mimetizar a exposição "humana real" aos poluentes, desde a fase intra-uterina até a fase adulta. 
Em nosso estudo observamos que os animais nascidos e mantidos até a fase adulta em ambiente cujo ar não era filtrado apresentaram aumento de MDA (marcador de lipoperoxidação) no córtex cerebral. Em termos de enzimas antioxidantes a nível cortical, verificamos que a SOD apresentou maior atividade no grupo $F$ (que nasceu e viveu até a idade adulta sob ar filtrado), não havendo diferença estatisticamente sugnificativa na atividade da catalase entre os grupos experimentais, embora apareça uma tendência de aumento da mesma para os grupos de animais submetidos à troca de ambiente (NF e NFF). Estes resultados demonstram que os grupos experimentais em que os animais em algum momento ficaram expostos à poluição atmosférica tiveram um consumo da SOD, com o intuito de diminuir a concentração de ânion superóxido e, possível acúmulo de lipídeos oxidados e que, a troca de ambiente protegeu estes animais em relação a lipoperoxidação. Também verificamos que a concentração de glutationa total foi menor no grupo FNF. Este achado sugere que após a troca do ambiente filtrado para o não filtrado a partir do partir do $21^{\circ}$ dia do período pós-natal, seja necessário a utilização desta susbtância para manter a atividade da enzima glutationa peroxidase a pleno com o objetivo de detoxificar o peróxido de hidrogênio resultante da reação de dismutação catalisada pela SOD (Halliwell, 2006). Após o restabelecimento do equilíbrio entre os oxidantes e antioxidantes, a tendência do organismo é retornar ao seu estado de estresse oxidativo basal, ou seja, o aumento da atividade das enzimas e da a concentração de glutationa total aos níveis normais no organismo. Assim, podemos sugerir que a troca de ambiente a partir do $21^{\circ}$ dia do período pós-natal do ambiente filtrado para o não filtrado (grupo FNF) pode 
desencadear mecanismos de proteção contra o estresse oxidativo. Xia e cols. (2006) explicaram o processo de adaptação ao estresse oxidativo através da descrição de três níveis de EO: nível 1 ou nível baixo de estresse oxidativo, no qual há resposta celular via fator de transcrição de resposta Nrf2, ativando os promotores dos genes da fase II e resultando na maior expressão de genes das enzimas antioxidantes. Nesse nível ocorre a adaptação dos organismos vivos ao estresse oxidativo demonstrada através das manifestações clínicas irrelevantes. No presente estudo, sugerimos que a adaptação aconteceu após a troca de ambiente filtrado para o não filtrado (grupo FNF), resultando, inicialmente, no consumo da glutationa total para que houvesse o aumento da atividade da enzima glutationa peroxidase e, após a restauração do equilíbrio entre substâncias oxidantes e antioxidantes, a GSHt retornaria a sua concentração inicial. No nível 2 de EO ocorre resposta celular inflamatória através da ativação do fator nuclear KB, MAPK, liberação de citocinas e lipoperoxidação. Os sintomas clínicos desta fase são: asma, efeitos adjacentes e aterosclerose (oxidação da lipoproteína de baixa densidade - LDL - low density protein). Nesse nível, não há adaptação e nem reversão dos danos causados pelo EO no organismo. Logo, poderíamos dizer que o grupo NF se encontraria nessa fase. $\mathrm{O}$ nível 3 seria a fase em que ocorreria a abertura dos poros mitocondriais, apoptose e necrose, ou seja, manifestações da toxicidade celular induzida pelo EO.

Em termos de processo inflamatório cerebral, Block e Calderón-Garcidueñas (2009) sugeriram que após o MP atingir o SNC, via bulbo olfatório ou via sistêmica, ocorre a ativação da microglia, em função da liberação de mediadores próinflamatórios induzida direta ou indiretamente pela inalação das partículas. A 
microglia ativada, por sua vez, produz também fatores pró-inflamatórios e neurotóxicos - IL-1 $\beta$, fator de necrose tumoral $\alpha$ (TNF $\alpha$ ), NO, $\mathrm{H}_{2} \mathrm{O}_{2}, \mathrm{O}_{2} \cdot \mathbf{A}$ produção do ânion superóxido, no meio extracelular, e a ativação da nicotinamida adenina dinucleotídeo fosfato oxidase (NADPH) são as vias responsáveis pela neurotoxicidade, originada a partir da ação destas células. Além disso, os metais de transição adsorvidos às partículas, como $\mathrm{Fe}, \mathrm{Cu}, \mathrm{V}, \mathrm{Cr}$, Ni, são responsáveis pela conversão do $\mathrm{H}_{2} \mathrm{O}_{2}$, produzido a partir da microglia, em $\mathrm{OH}^{-\bullet}$, através da reação de Fenton (figura 8, reações 3 e 4). As duas $\mathrm{EAO}, \mathrm{O}_{2}^{-\bullet}$ e $\mathrm{OH}^{-\bullet}$, causam lipoperoxidação dos lipídeos de membrana, diminuição da sua fluidez e consequente morte celular por apoptose (Milton, 2004; Xia e cols., 2006; Mohankumar e cols., 2008). Outro mecanismo que poderia explicar o aumento de MDA cortical no grupo NF seria o aumento de $\mathrm{Cd}$ no sangue total desses animais. O cádmio inalado pela mãe passa para o feto via transplacentária. Este elemento traço tóxico atinge o SNC de ratos até duas semanas após o parto, pois a BHE ainda está em formação (Takeda, 2000; Hartz e cols., 2008, Zheng e cols., 2003). A concentração de Cd elevada no grupo NF, exposto desde a fase intra-uterina até a fase adulta ao ar poluído, está indiretamente envolvida no aumento da lipoperoxidação no córtex cerebral. O Cd promove o deslocamento de $\mathrm{Fe}$ e $\mathrm{Cu}$ das suas proteínas de armazenamento, ferritina e ceruplasmina, respectivamente, aumentando a concentração destes metais no meio intracelular e, consequentemente, a produção de radical via reação de Fenton catalisada pelos mesmos (Nordberg e cols., 2007a; Norberg e cols., 2007b; Sandstead e Au, 2007; Ellingsen, Horn e Aaseth, 2007). 
No hipocampo, o grupo FNF apresentou a maior concentração de MDA assim como a menor concentração de GSHt em relação aos outros grupos. Sugerimos que os ratos do grupo FNF apresentaram lipoperoxidação devido à troca do ambiente limpo para o poluído. Como nasceram em ambiente cujo ar era filtrado, não desenvolveram nenhum tipo de mecanismo de adaptação ao EO após serem trocados de ambiente para o ar não filtrado, ou seja, nível 2 de EO de acordo com a classificação de Xia e cols. (2006). Conforme citado anteriormente, no nível 2 de EO não haveria adaptação e nem mesmo reversão dos danos oxidativos causados pela exposição aos poluentes após o $21^{\circ}$ dia do período pós-natal.

Por fim, no estriado, o grupo que apresentou lipoperoxidação foi o NF. Esse grupo não apresentou aumento de atividade das enzimas antioxidantes e nem da concentração de glutationa total. Logo, sugerimos que o fato dos animais terem nascido e vivido em ambiente poluído aumentou o dano oxidativo, pois as atividades das enzimas não se alteraram, ou seja, o organismo não reagiu ao estímulo nocivo ambiental. Entretanto, o FNF apresentou aumento da concentração da glutationa total. Esses animais, nascidos sob ar filtrado e trocados de ambiente após o $21^{\circ}$ dia do pós-natal, foram protegidos pelo aumento da atividade da glutationa peroxidase devido à elevação da concentração da glutationa total (GSH + GSSG). O substrato desta enzima, o GSH, degrada o peróxido de hidrogênio em excesso resultante da reação de dismutação do ânion superóxido catalisada pela SOD devido à baixa concentração de catalase no encéfalo (Halliwell, 2006). 
O grupo NFF não apresentou aumento de lipoperoxidação em nenhuma das três estruturas encefálicas estudadas. Sugerimos que os animais deste grupo nascidos em ambiente inóspito (poluído), durante a fase intra-uterina, absorveram, através do cordão umbilical, altas concentrações de elementos traço essenciais (Cu, Se e Zn) com o objetivo de fortalecer a sua proteção antioxidante enzimática. Estes elementos são cofatores das enzimas SOD CuZn e glutationa peroxidase e, por isso, as concentrações das mesmas estavam elevadas. Ao trocarmos estes ratos de ambiente, as concentrações se mantiveram altas, pois o ar que respiravam era filtrado. Dentre as funções dos elementos traço essenciais destacam-se: o Zn, necessário para o desenvolvimento da extensa rede neuronal e do cerebelo em relação às outras regiões (Takeda, 2000); o Se, proveniente das selenoproteínas, faz-se necessário para o crescimento do embrião e o $\mathrm{Cu}$, um dos cofatores da enzima SOD, responsável pelo aumento da concentração e da atividade da mesma, o que melhora a proteção antioxidante contra o estresse oxidativo (Högberg e Alexander, 2007).

Logo, nossos resultados demonstraram que cada estrutura encefálica apresenta um perfil diferente de resposta em termos de EO induzido pela inalação de poluentes atmosféricos. Além disso, sugerimos que a troca de ambiente, imediatamente após o término da lactação, pode modular as defesas antioxidantes.

Em termos de análise histológica, no presente estudo, utilizamos as técnicas estereológicas com o intuito de dimensionar o volume do córtex, do hipocampo e 
do estriado, bem como estimar o número de neurônios e neuroglia a partir dos três eixos $x, y, z$, ou seja, tridimensionalmente.

Em nosso trabalho, verificamos que o grupo de animais NF (nascido e mantido em câmara cujo ar era não filtrado por 150 dias) apresentou maior número de neurônios e neuroglia quando comparado aos demais grupos de animais. Entretanto, não houve diferença estatisticamente significativa no volume desta estrutura.. Além disso, quando analisamos a concentração de Cd no sangue total, percebemos que esta foi maior no referido grupo quando comparada com as dos grupos F, FNF e NFF. É importante ressaltar que a concentração de elementos traço no sangue dos animais está diretamente relacionada com a concentração neuronal dos mesmos, visto que BHE dos ratos somente estará completamente formada duas semanas após o nascimento (Takeda, 2000). Pensando-se que houve aumento do número de neurônios, sem aumento significativo do volume desta estrutrura encefálica, sugerimos que ocorreu uma diminuição no desenvolvimento sináptico e dendrítico no córtex do grupo NF. Assim, embora o número de neurônios e de neuroglia sejam maiores, o número de conexões (sinapses) e dendritos pode ser menore, o que explicaria a diminuição da memória discriminativa de curta duração verificada nesse mesmo grupo no teste de reconhecimento espontâneo de objetos, sendo o Cd um mediador desta resposta. Esta explicação pode ser embasada através do estudo de Ohtani-Kaneko e colaboradores (2008) que, utilizando cultura de células neuronais, demonstraram que uma concentração de $\mathrm{Cd}$ de $10 \mathrm{nM}$ foi suficiente para suprimir o desenvolvimento de dendritos e sinapses. Os mesmos pesquisadores demonstraram que o $\mathrm{Cd}$ alterou a expressão de várias proteínas 
responsáveis pelo desenvolvimento neuronal: dihidropirimidinase proteína 2, 14-33-epislon e calmodulina. Em relação ao aumento do número de neuroglia no córtex de animais do grupo NF, sugerimos que o mesmo ocorreu em função de resposta inflamatória, bem como com o intuito de ocupar o espaço disponível pelo menor número de conexões e dendritos. A questão do desenvolvimento de neuroinflamação é bastante descrita por Calderón-Garcidueñas e cols. (2003a; 2003b; 2004; 2008b) que demonstraram que a neuroinflamação é resultante da ativação da microglia no SNC resultante da exposição aos poluentes tanto de cães, quanto de crianças e jovens adultos na cidade do México. Além disso, na literatura encontramos o trabalho de Balmiki e colaboradores (2009), os quais mostraram que o aumento da neuroglia (em estudo com cultura de células) ocorre a partir do décimo segundo dia, sendo que em um primeiro momento, predomina o aumento de neurônios. Estes mesmos autores demonstraram que as células gliais foram responsáveis pela preservação dos neurônios até o vigésimo quarto dia de cultura. Em resumo, baseados em nossos resultados e nos trabalhos citados conjecturamos que os neurônios do córtex, na presença de $\mathrm{Cd}$ estabeleceram um menor número de sinapses e as suas expansões dendríticas diminuíram, o que explicaria o prejuízo no desempenho no teste de memória discriminativa de curta duração de animais nascidos e mantidos sob ar não filtrado.

Quanto ao hipocampo, de forma semelhante ao córtex, não houve diferença significativa no volume do mesmo. O número de neurônios foi maior no grupo NF quando comparados ao F, NFF e FNF, entretanto, não houve diferença significativa do número de células gliais entre os grupos experimentais. Quanto ao teste que 
investiga prejuízo da memória espacial, verificamos que os animais deste grupo (NF) não apresentaram alterações no tempo de latência em relação à procura da plataforma no teste do labirinto de Morris, comportam-se de forma semelhante aos demais grupos experimentais. Como esse grupo nasceu e foi mantido até a idade adulta sob ar não filtrado, sugerimos que o maior número de neurônios na região CA1 do hipocampo desses animais foi devido, provavelmente, ao processo de neurogênese, ou seja, a sobrevivência, proliferação e diferenciação das células precursoras neuronais localizadas no giro denteado hipocampal através do aumento do fator de crescimento neurotrófico derivado do encéfalo (BNDF - brain derived neurotrophic factor), similar ao que acontece em cultura de células de hipocampo de ratos (Li e cols., 2009). Além disso, Tang e cols. (2009) descreveram que a neurogênese no giro denteado hipocampal ocorre devido à proliferação de células precursoras neuronais e não da morte das mesmas. Dessa forma, o hipocampo preservaria a sua integridade em termos funcionais. Esse processo na idade adulta é um exemplo de plasticidade neural (Rivas-Arancibia e cols., 2009). Assim, possivelmente, o hipocampo dos animais do grupo NF se adaptou ao ambiente no qual viviam induzindo, através do processo de plasticidade neural, a neurogênese das células proliferativas neuronais no giro denteado do hipocampo, bem como a sua migração para outras regiões hipocampais. Quando ao grupo FNF (nascido em ambiente sob ar filtrado e trocado para o ar não filtrado após o período de lactação, onde permaneceu até a idade adulta), que apresentou lipoperoxidação no hipocampo em relação aos outros grupos experimentais, sugerimos que o processo de memorização espacial dependente do hipocampo em termos 
funcionais, mas independente de mecanismos modulados por substâncias oxidantes.

Em termos de habituação, uma das estruturas subcorticais envolvidas é o estriado. Esta estrutura não apresentou diferença significativa no seu volume, bem como no número de neurônios e células neurogliais. Logo, sugerimos que não houve alterações na morfologia das células neuronais. Como os animais preservaram a sua capacidade de habituação a estímulos seqüenciais no teste de reconhecimento de objetos, esse dado nos permite sugerir que a função do estriado foi preservada. Estudos anteriores do nosso laboratório (Zanchi e cols., 2008; 2010) corroboram este achado, pois demonstraram que a lipoperoxidação no hipocampo e no estriado não influenciaram na capacidade de habituação dos animais ao ambiente do campo aberto. Nesse caso, possivelmente, o comportamento de habituação não foi prejudicado, pois este é proveniente de estruturas subcorticais como o estriado e considerado primitivo, ou seja, garante a sobrevivência do animal. 


\section{CONCLUSÃO}

Considerando os resultados obtidos e apresentados, concluímos que:

a) a exposição à poluição atmosférica ambiental durante a vida intra-uterina e o período de lactação (até $021^{\circ}$ dia de vida) não causou alteração no desenvolvimento dos filhotes machos;

b) a exposição à poluição atmosférica ambiental durante a vida intra-uterina e o período de lactação (até o $21^{\circ}$ dia de vida) causou diminuição da memória discriminativa de curta duração; aumento da capacidade de habituação e não modificou a memória espacial;

c) a troca de ambiente não modificou a memória discriminativa de curta duração; a troca de ambiente - de filtrado para não filtrado- promoveu um aumento da habituação; a troca de ambiente não causou alteração da memória espacial;

d) a exposição à poluição atmosférica ambiental durante a vida intra-uterina e o período de lactação (até o $21^{\circ}$ dia de vida) causou aumento da lipoperoxidação no córtex cerebral e no estriado; não promoveu modificação da taxa de lipoperoxidação no hipocampo;

e) a troca de ambiente de filtrado para não filtrado (FNF) promoveu um aumento da lipoperoxidação no hipocampo; não promoveu modificação da taxa de lipoperoxidação no córtex cerebral e no estriado;

f) a exposição à poluição atmosférica ambiental durante a vida intra-uterina e o período de lactação (até o $21^{\circ}$ dia de vida) causou uma diminuição apenas da atividade SOD, não havendo alteração da atividade da catalase e da 
concentração de GSHt no córtex cerebral; no hipocampo e no estriado não houve alteração da atividade da SOD e da catalase, nem modificação da concentração de GSHt;

g) a troca de ambiente de filtrado para não filtrado (FNF) causou diminuição da GSHt, não modificou a atividade da SOD e catalase no córtex; no hipocampo promoveu uma diminuição na GSHt, sem modificação da atividade da SOD e catalase; no estriado, promoveu diminuição da atividade da SOD, sem alteração da catalase e aumento da concentração de GSHt;

h) a exposição à poluição atmosférica ambiental durante a vida intra-uterina e o período de lactação (até o $21^{\circ}$ dia de vida) causou um aumento da concentração maior de Cd no sangue total dos animais e o grupo não exposto apresentou a menor concentração de antimônio no sangue total; não houve modificação na concentração de chumbo;

i) a troca de ambiente de filtrado para não filtrado (FNF) causou um aumento da concentração maior de $\mathrm{Cd}$ no sangue total dos animais; a troca de ambiente não causou alteração na concentração de antimônio e de chumbo;

j) a exposição à poluição atmosférica ambiental durante a vida intra-uterina e o período de lactação (até $\circ 21^{\circ}$ dia de vida) não causou alteração na concentração de cobre, zinco, selênio e manganês no sangue total dos animais;

k) a troca de ambiente de não filtrado para filtrado (NFF) causou aumento nas concentrações de cobre, selênio e zinco, mas não alterou a concentração de manganês no sangue total dos animais; 
I) a exposição à poluição atmosférica ambiental durante a vida intra-uterina e o período de lactação (até o $21^{\circ}$ dia de vida) causou aumento do número de neurônios e neuroglia corticais; aumento da neuroglia no hipocampo; não promoveu alteração do número de neurônios e neuroglia no estriado;

m) a troca de ambiente não causou alteração no número de neurônios ou neuroglia no córtex cerebral, hipocampo e estriado.

Em resumo, a exposição de ratos machos adultos durante a fase intrauterina e período de lactação à poluição atmosférica a nível ambiental na cidade de Porto Alegre não causou alteração no desenvolvimento dos animais, entretanto diminuiu a memória discriminativa de curto prazo, aumentou a capacidade de adaptação e não modificou a memória espacial. Os oxidantes em nível de córtex cerebral possuem papel importante no mecanismo responsável pelo prejuízo da memória discriminativa e não estão envolvidos com a diminuição da memória espacial.

Mais estudos serão necessários para investigar o número de conexões e sinapses corticais, bem como para analisar os mediadores pró-inflamatórios no encéfalo para confirmar se o aumento de neuroglia cortical foi o início de neuroinflamação. Outros testes de memória serão necessários em animais expostos à poluição para estudar memória de longa duração e de trabalho. Ainda, precisaremos investigar se ocorrem alterações em termos de morfologia neuronal nos animais expostos à poluição atmosférica. 


\section{REFERÊNCIAS BIBLIOGRÁFICAS}

Abel EL, Hannigan JH. Effects of chronic forced swimming and exposure to alarm substance: physiological and behavioral consequences. Physiol. Behav. 1992; 52 (4): 781-785.

Aebi H. Catalase in vitro. Meth. Enzymol. 1984; 105: 121.

Aggleton JP, Hunt PR, Rawlins JN. The effects of hippocampal lesions upon spatial and non-spatial tests of working memory. Behav. Brain Res. 1986; 19(2): 133-146.

Baddeley AJ, Gundersen HJ, Cruz-Orive LM. Estimation of surface area from vertical sections. J. Microsc. 1986; 142: 259-276.

Balmiki R, Bailey JA, Sarkar S, Lahiri DK. Molecular and immunocytochemical characterization of primary neuronal cultures from adult rat brain: differential expression of neuronal and glial protein markers. J. Neurosci. Methods 2009; 184: 294-302.

Batista BL, Rodrigues JL, Nunes JA, Tormen L, Curtius AJ, Jr. F Barbosa. Exploiting dynamic reaction cell inductively coupled plasm mass spectrometry (DRC-ICP-MS) for sequential determination of trace elements in blood using a dilute-and-shoot procedure. Anal. Chim. Acta 2009; 639: 13-18.

Bekinschtein P, Cammarota M, Katche C, Slipczuk L, Rossato JI, Goldin A, Izquierdo I, Medina JH. BDNF is essential to promote persistence of long-term memory storage. Proc. Natl. Acad. Sci. USA. 2008; 105 (7): 2711-2716.

Bernardi R, Barros HMT. Carbamazepine enhances discriminative memory in rat model of epilepsy. Epilepsy 2004; 45 (11): 1443. 
Bérubé $K$, Balharry $D$, Jones $T$, Moreno $T$, Hayden $P$, Sexton $K$, Hicks $M$, Merolla $L$, Timblin C, Shukla A, Mossman R. Characterization of airborne particulate matter and related mechanisms of toxicity: an experimental approach. In: Ayres J, Maynard R, Richards R. Air pollution and brain health. 1a ed. Londres: Imperial College Press; 2006. p. 69-110.

Block ML, Calderón-Garcidueñas L. Air pollution: mechanisms of neuroinflammation and CNS disease. Trends in neuroscience 2009; 32 (9): 506-516.

Bondy SC, Lebel CP. The relationship between excitotoxicity and oxidative stress in the central nervous system. Free Radic. Biol. Med. 1993; 14: 633-542.

Brasil. Conselho Nacional do Meio Ambiente. Resolução 03/90 de 28/06/1990. Brasília: CONAMA; 1990.

Braun JM, Kahn RS, Froehlich T, Auinger P, Lanphear BP. Exposure to environmental toxicants and attention deficit hyperactivity disorder in US children. Environ. Health Perspect. 2006; 114 (12): 1904-1909.

Calderón-Garcidueñas L, Rodriguez-Alcaraz A, Valencia-Salazar G, Mora-Tascareño A, García R, Osnaya N, Villarreal-Calderón A, Devlin RB, Van Dyke T. Nasal biopsies of children exposed to air pollutants. Toxicol. Pathol. 2001b; 29 (5): 558-564.

Calderón-Garcidueñas L, Azzarelli B, Acuna H, Garcia R, Todd MG, Osnaya N, Monroy S, Tizapanti MDR, Carson JL, Villarreal-Calderón A, Rewcastle B. Air pollution and brain damage. Toxicol. Pathol. 2002; 30 (3): 373-389.

Calderón-Garcidueñas L, Maronpot RR, Torres-Jardón R, Henríquez-Roldán C, Barragán-Mejía G, Valencia-Salazar G, González-Maciel A, Reynoso-Robles R, Villarreal-Calderón $\mathrm{R}$, Reed $\mathrm{W}$. Pediatric respiratory and systemic effects of chronic air pollution exposure nose, lung, heart and brain pathology.Toxicol. Pathol. 2003a; 31: 524-538. 
Calderón-Garcidueñas L, Maronpot RR, Torres-Jardón R, Henríquez-Roldán $C$, Schoonhoven R, Acuña-Ayala H, Villarreal-Calderón A, Nakamura J, Fernando R, Reed W, Azzarelli B, Swenberg JA. DNA damage in nasal and brain tissues of canines exposed to air pollutants is associated with evidence of chronic brain inflammation and neurodegeneration. Toxicol. Pathol. 2003b; 31: 524-538.

Calderón-Garcidueñas L, Reed W, Maronpot RR, Henríquez-Roldán C, DelgadoChavez R, Calderón-Garcidueñas A, Dragustinovis I, Franco-Lira M, Aragón-Flores M, Solt AC, Altenburg $M$, Torres-Jardón $R$, Swenberg JA. Brain inflammation and Alzheimer's-like pathology in individuals exposed to severe air pollution. Toxicol.Pathol. 2004; 32:650-658.

Calderón-Garcidueñas L, Solt AC, Henriquez-Roldán C, Torres-Jardón R, Nuse B, Herritt L, Villarreal-Calderón R, Osnaya N, Stone I, Garcia R, Brooks DM, GonzálezMaciel A, Reynoso-Robles R, Delgado-Chávez R, Reed W. Long-term air pollution exposure is associated with neuroinflammation an altered innate immune response, disruption of the blood-brain barrier, ultrafine particulate deposition and accumulation of amyloid beta-42 and alpha-synuclein in children and young adults. Toxicol. Pathol. 2008a; 36 (2): 289-310.

Calderón-Garcidueñas L, Mora-tiscareño A, Ontiveros E, Gómez-Garza G, BarragánMejía G, Chapman S, Valencia-Salazar G, Jewells V, Maronpot RR, Henriquez-Roldán C, Pérez-Guillé B, Torres-Jardón R, Herritt L, Brooks D, Osnaya-Brizuela N, Monroy MD, González-Maciel A, Reynoso-Robles R, Villarreal-Calderón R, Solt AC, Engle RW. Air pollution, cognitive deficits and brain abnormalities: a pilot study with children and dogs. Brain Cogn. 2008b; 68 (2): 117-127.

Campbell A. Mechanisms by which metals promote events connected to neurodegenerative diseases. Brain Res. Bull. 2001; 55: 125-132.

Cançado JED, Braga A, Pereira LAA, Arbex MA, Saldiva PHN, Santos U. Repersussões clínicas da exposição à poluição atmosférica. J. Bras.Pneumol. 2006; 32 (Suppl 1):S5S11.

Collier TJ, Routtenberg A. Selective impairment of declarative memory following stimulation of dentate gyrus granule cells: a naloxone-sensitive effect. Brain Res. 1984; 24; 310(2): 384-387. 
Damaceno-Rodrigues NR, Veras MM, Negri EM, Zanchi AC, Rhoden CR, Saldiva PH, Dolhnikoff $M$, Caldini EG. Effect of pre- and postnatal exposure to urban air pollution on myocardial lipid peroxidation levels in adult mice. Inhal Toxicol. 2009; 21(13): 1129-1137.

Del Maestro RF. An approach to free radicals in medicine and biology. Acta Physiol. Scand. 1980; 492: 153-167.

Departamento de trânsito do Rio Grande do Sul. Levantamento da frota veicular. Porto Alegre: DETRAN-RS; 2001.

Derelanko MJ, Hollinger MA. Handbook of Toxicology. 2a ed. Estados Unidos da América: Taylor e Francis; 2002. Cap. 22, p. 918-959.

Dorph-Petersen KA, Nyengaard JR, Gundersen HJ. Tissue shrinkage and unbiased stereological estimation of particle number and size. J. Microsc. 2001; 201 (Pt 3): 232-246.

Ellingsen DG, Horn N, Aaseth J. Copper. In: Nordberg GF, Fowler BA, Nordberg M, Friberg L. Handbook on the Toxicology of Metals. 3a ed. Estados Unidos da America: Elsevier; 2007. Cap. 26, p. 529-546.

Ennaceur A, Delacour J. A new one-trial for neurobiological studies of memory in rats. 1: behavioral data. Behavioral Brain Res. 1988; 31:47-59.

Ennaceur A, Cavoy A, Costa JC, Delacour J. A new one trial for neurobiological studies of memory in rats II: effects of piracetam and pramiracetam. Behvioral Brain Res. 1989; 33: 197-207.

Ennaceur A, Aggleton JP. The effects of neurotoxic lesions of the perirhinal cortex combined to fornix transection on object recognition memory in the rat. Behav. Brain Res. 1997; 88(2): 181-193. 
Evans OB, Hutchins JB. Desenvolvimento do Sistema nervoso. In: Haines DE. Neurociência fundamental para aplicações básicas e clínicas. Tradução de Luciane Faria de Souza Fontes. 3a ed. Rio de Janeiro: Elsevier; 2006. Cap. 5, p. 85-106.

Felten DL, Józefowicz RF. Atlas de neurociência humana de Netter. Tradução de Casimiro García Fernández, Sonia Maria Lauer Garcia. Porto Alegre: Artmed; 2005.

Ferreira ALA, Matsubara LS. Radicais livres: conceitos, doenças relacionadas, sistema de defesa e estresse oxidative. Ver. Assoc. Med. Bras. 1997; 43 (1): 61-68.

Ferreira Rivero DHR, Soares SRC, Lorenzi-Filho G, Saiki M,Godleski JJ, Antonangelo L, Dolhnikoff M, Saldiva PHN. Acute cardiopulmonary alterations induced by fine particulate matter of São Paulo, Brazil. Toxicol. Sci. 2005; 85: 898-905.

Filho APS. Sedação, analgesia e anestesia geral em ratos. In: Rhoden EL, Rhoden CR, organizadores. Princípios e técnicas em experimentação animal. 1a ed. Porto Alegre: Editora da UFRGS; 2006. p. 45-54.

Forman HJ, Fukuto JM, Torres M. Redox signaling: thiol chemistry defines which reactive oxygem species can act as second messengers. Am. J. Physiol. Cell Physiol. 2004; 287: 246-256.

Forman HJ, Maiorino M, Ursini F. Signaling functions of reactive oxygen species. Biochemistry 2010; in press.

Freitas C, Bremner SA, Gouveia N, Pereira LAA, Saldiva PHN. Internações e óbitos com a poluição atmosférica em São Paulo, 1993 a 1997. Rev. Saude Pública 2004; 38 (6): 751-757.

Fundação Estadual de Proteção Ambiental - Rio Grande do Sul. Monitoramento da qualidade do ar. Porto Alegre: FEPAM; 2001. 
Gazzaniga MS, Ivry RB, Mangun GR. Neurociência cognitiva: a biologia da mente. Tradução de Carlos Alexandre Netto. 2a ed. Porto Alegre: Artmed; 2006. Cap.8, p. 319-368.

Gilboa SM, Mendola R, Olshan AF, Langlois PH, Savitz DA, Loomis D, Herring AH, Fixler DE. Relation between ambient air quality and selected birth defects, seven country study, Texas, 1997-2000. Am. J. Epidemiol. 2005; 162 (3): 235-238.

Glinianaia SV, Rankin J, Bell R, Pless-Mulloli T, Howel D. Particulate air pollution and fetal health. Epidemiology 2004; 15(1): 36-45.

Goldim JR, Pesquisa em saúde: Leis, normas e diretrizes, 2a ed. Hospital de Clínicas de Porto Alegre: Grupo de Pesquisa e Pós-Graduação, 1995.

Gundersen HJ, Bagger P, Bendtsen TF, Evans SM, Korbo L, Marcussen N, Moller A, Nielsen K, Nyengaard JR, Pakkenberg B. The new stereological tools: disector, fractionator, nucleator and point sampled intercepts and their use in pathological research and diagnosis. APMIS 1988; 96 (10): 857-881.

Gundersen HJ, Jensen EB. The efficiency of systematic sampling in stereology and its prediction. J.Microsc. 1987; 147 (Pt 3): 229-263.

Gurgueira SA, Lawrence J, Coull B, Murthy K, González-Flecha B. Rapid increases in the steady-state concentration of reactive oxygen species in the lungs and heart after particulate air pollution inhalation. Environ. Health Perspect. 2002; 110 (8): 749-755.

Ha M, Kwon H, Lim M, Jee Y, Hong Y, Leem J, Sakong J, Bae J, Hong S, Roh Y, Jo S. Low blood levels of lead and mercury and symptons of attention deficit hyperactivity in children: a report of the children's health and environment research (CHEER). Neurotoxicology 2009; 30: 31-36. 
Hafner L. Efeito de glicosaminoglicanos na prevenção de trombose em enxertos veno-venosos microcirúrgicos no rato. [Tese] Botucatu: Universidade Estadual Paulista "Júlio Mesquita Filho", 1997.

Halliwell B, Gutteridge JM. Free radicals in biology and medicine. 4a ed. Oxford: Oxford University Press; 2006.

Halliwell B, Gutterigde JM. Oxygen radicals and the nervous system. TINS 1985; 2226.

Halliwell B. Oxidative stress and neurodegeneration: where are we now? J. Neurochem. 2006; 97: 1634-1658.

Halliwell B. Reactive oxygen species and the central nervous system. J. Neurochem. 1992; 51 (5): 1609-1623.

Högberg J, Alexander J. Selenium. In: Nordberg GF, Fowler BA, Nordberg M, Friberg L. Handbook on the Toxicology of Metals. 3a ed. Estados Unidos da America: Elsevier; 2007. Cap. 38, p. 783-807.

Hosseini-Sharifabad M, Nyengaard JR. Design-based estimation of neuronal number and individual neuronal volume in the rat hippocampus. J. Neurosci. Methods.2007; 162: 206-214.

Hougaard K, Jensen KA, Nordly P, Taxvig C, Vogel U, Saber AT, Wallin H. Effects of prenatal exposure to diesel exhaust particles on postnatal development, behavior, genotoxicity and inflammation in mice. Particle and Fibre Toxicology. 2008. Disponível em: www.particleanfibretoxicology.com/content/5/1/3.

Howard CV, Reed MG. Unbiased stereology: three-dimensional measurement in microscopy. 2a ed. Abingdon, Oxon: Garland Science/Bios Scientific; 2005.

Izquierdo I. Memória. 1a ed. Porto Alegre: Artmed; 2002. 
Izquierdo I. Questões sobre memória. 1a ed. Porto Alegre: Editora Unisinos; 2004. $19 \mathrm{v}$.

Junqueira VBC. Aging and oxidative stress. Mol. Aspects Med. 2004; 25: 5-16.

Kaiser J. Evidence mounts that tiny particles can kill. Science 2000; 289: 22-23.

Kelly A, Laroche S, Davis S.Activation of mitogen-activated protein kinase/extracellular signal-regulated kinase in hippocampal circuitry is required for consolidation and reconsolidation of recognition memory. J. Neurosci. 2003; 23 (12): 5354-5360.

Laboratório de Poluição Atmosférica Experimental, Laboratório de Análise de Processos Atmosféricos. Projeto de avaliação ambiental em regiões metropolitanas. São Paulo: LPAE, LAPAt; 2009.

Lacasãna $M$, Esplugues $A$, Ballester $F$. Exposure to ambient air pollution and prenatal and early childhood health effects. Eur. J. Epidemiol. 2005; 20: 183-199.

Lawers F, Cassot F, Lawers-Cances V, Puwanarajah P, Duvernoy H. Morphometry of the human cerebral cortex microcirculation: general characteristics and spacerelated profiles. Neurolmage 2008; 39: 936-948.

Lent R. Cem bilhões de neurônios: conceitos fundamentais de neurociências. São Paulo: Editora Atheneu; 2004.

Lewtas J. Air pollution combustion emissions: characterization of causative agents and mechanisms associated with cancer, reproductive and cardiovascular effects. Mutat. Res. 2007; 636: 95-133.

Lichtenfels AJF, Gomes JB, Pieri PC, Miraglia SG El K, Hallak J, Saldiva PHN. Increased levels of air pollution and a decrease in the human and mouse male-to-female ratio in São Paulo, Brazil. Fertil. Steril. 2007; 87(1): 230-232. 
$\mathrm{Li}$ T, Jiang L, Zhang $\mathrm{X}$, Chen $\mathrm{H}$. In-vitro effects of brain-derived neurotrophic factor on neural progenitor/stem cells from rat hippocampus. Neuroreport. 2009; 20(3): 295-300.

Lin CA, Pereira LAA, Conceição GM de Souza, Kishi HS, Jr. Milani R, Braga ALF, Saldiva PHN. Association between air pollution and ischemic cardiovascular emergency room visits. Environ.Res. 2003; 92:57-63.

Lin CA, Pereira LAA, Nishioka DC, Conceição GMS, Braga ALF, Saldiva PHN. Air pollution and neonatal deaths in São Paulo, Brazil. Braz. J. Med. Biol. Res. 2004; 37: 765-770.

Maisonet M, Correa A, Misra D, Jaakkola JK. A review of the literature on the effects of ambient air pollution on fetal growth. Environ. Res. 2004; 95: 106-115.

Mannes T, Jalaludin B, Morgan G, Lincoln D, Sheppeard V, Corbett S. Impact of ambient air pollution on birth weight in Sydney, Australia. Occup. Environ. Med. 2005; 62:524-530.

Marklund S, Marklund G. Involvement of the superoxide anion radical in the autoxidation of pyrogallol and a convenient assay for superoxide dismutase. Eur. J. Biochem. 1974; 47: 469-474.

Maroziene L, Grazuleviciene R. Maternal exposure to low level air pollution and pregnancy outcomes: a population-based study. Environ. Health: a global access science source. 2002. Disponível em: http: www.ehjournal.net/content/1/1/6.

Martins LD, Martins JA, Freitas ED, Mazzoli CR, Gonçalves FLT, Ynoue RY, Hallak R, Toledo T, Albuquerque A, Andrade MF. Potential health impacto of ultrafine particles under clean and polluted urban atmospheric conditions: a model-based study. Air Qual. Atmos. Health. 2009. Disponível em: http: www.springerlink.com.

Mayhew TM. Stereology and the placenta: where's the point - a review. Placenta 2006; 27 (1): 17-25. 
Mayhew TM. Taking tissue samples from the placenta: an illustration of principles and strategies. Placenta 2008; 29: 1-14.

Milton NGN. Role of hydrogen peroxide in the aetiology of Alzheimer's disease. Drugs Aging 2004; 21: 82-100.

Miraglia SGK, Saldiva PHN. An evaluation of air pollution health impacts and costs in São Paulo, Brazil. Environ Manage. 2005; 35 (5): 667-676.

MohanKumar SMJ, Campbell A, Block M, Veronesi B. Particulate matter, oxidative stress and neurotoxicity. Neurotoxicology 2008; 29: 479-488.

Nordberg GF. Gerhardsson L, Broberg K, Mumtaz M, Ruiz P, Fowler B. Interactions in Metal Toxicology. In: Nordberg GF, Fowler BA, Nordberg M, Friberg L. Handbook on the Toxicology of Metals. 3a ed. Estados Unidos da America: Elsevier; 2007a. Cap. 7, p. 117-139.

Nordberg GF, Nogawa K, Nordberg M, Friberg LT. Cadmium. In: Nordberg GF, Fowler BA, Nordberg M, Friberg L. Handbook on the Toxicology of Metals. 3a ed. Estados Unidos da America: Elsevier; 2007b. Cap. 23, p. 445-486.

Neves CMM. Lipoperoxidação no encéfalo de rato submetido à isquemia global transitória. [Dissertação] Porto Alegre: Universidade Federal do Rio Grande do Sul; 1997.

Oberdörster G, Maynard A, Donaldson K, Castranova V, Fitzpatrick J, Ausman K, Carter J, Karn B, Kreyling W, Lai D, Olin S, Monteiro-Riviere N, Warheit D, Yang H and a report from the ILSI Research Foundation/Risk Science Institute Nanomaterial Toxicity Screening Working Group. Principles for characterizing the potential human health effects from exposure to nanomaterials: elements of screening strategy. Particle and Fibre. Toxicology. 2005a. Disponível em: www.particleanfibretoxicology.com/content/2/1/8. 
Oberdörster G, Oberdörster E, Oberörster J. Nanotoxicology: an emerging discipline evolving from studies of ultrafine particles. Environ. Health Perspect. 2005b; 113 (7): 823-839.

Oberdörster G, Utell MJ. Ultrafine particles in the urban air: to the respiratory tract - and beyond? Environ. Health Perspect. 2002; 110 (8): A440-A441.

Oga S. Fundamentos de Toxicologia. 1a Ed. São Paulo: Editora Atheneu; 2003. Partes 1 e 2, p. 1-137.

Ohtani-Kaneko R, Tazawa H, Yokosuka M, Yoshida M, Satoh M, Watanabe C. Supressive effects of cadmium on neurons and affected proteins in cultured developing cortical cells. Toxicology 2008; 253 (1-3): 110-116.

Organização Mundial da Saúde. Air quality guidelines: global update. Bonn: OMS; 2005.

Perera FP, Rauh V, Whyatt RM, Tsai W, Tang D, Diaz D, Hoepner L, Barr D, Tu Y, Camann D, Kinney P. Effect of prenatal exposure to airborne polycyclic aromatic hydrocarbons on neurodevelopment in the first 3 years of life among inner-city children. Environ. Health Perspect. 2006; 114 (8): 1287-1292.

Perera FP, Li TY, Zhou ZJ, Yuan T, Chen YH, Qu L, Rauh VA, Zhang Y, Tang D. Benefits of reducing prenatal exposure to coal-burning pollutants to children's neurodevelopment in China. Environ. Health Perspect. 2008; 116 (10): 1396-1400.

Perera FP, Zhigang L, Whyatt R, Hoepner L, Wang S, Camann D, Rauh V. Prenatal airborne polycyclic aromatic hydrocarbon exposure and child IQ at age 5 years. Pediatrics 2009; 124 (2): 195-202. 
Peters A, Veronesi B, Calderón-Garcidueñas L, Gehr P, Chen LC, Geiser M, Reed W, Rothen-Rutishauser B, Schürch S, Schulz H. Translocation and potential neurological effects of fine and ultrafine particles: a critical update. Particle and Fibre Toxicology. Post Online [internet]. 2006. Available from: www. Particleanfibretoxicology.com/content/3/1/13.

Reliene R, Hlavacova A, Mahadevan B, Baird WM, Schiestl RH. Diesel exhaust particles cause increased levels of DNA deletions after transplacental exposure in mice. Mutat. Res. 2005; 571: 245-252.

Rhoden CR, Maslinkiewicz A, Pereira MSM, Rhoden EL. Eutanásia em animais de laboratório. In: Rhoden EL, Rhoden CR, organizadores. Princípios e técnicas em experimentação animal. 1a ed. Porto Alegre: Editora da UFRGS; 2006. p. 55-58.

Rhoden CR, Rhoden EL, Menti E, Lazzari RM, Maslinkiewicz A. Métodos de identificação em animais de experimentação. In: Rhoden EL, Rhoden CR, organizadores. Princípios e técnicas em experimentação animal. 1a ed. Porto Alegre: Editora da UFRGS; 2006. p. 35-38.

Rivas-Arancibia S, Dorado-Martinez C, Borgonio-Pérez G, Hiriart-Urdanivia $M$, Verdugo-Diaz L, Durán-Vázquez A, Colin-Baranque L, Avila-Costa MR. Effects of taurine on ozone-induced memory déficits and lipid peroxidation levels in brain of young, mature and old rats. Environ. Res. 2000; 82: 7-17.

Rivas-Arancibia S, Guevara-Guzmán R, López-Vidal Y, Rodríguez-Martinez E, Gomes $M Z$, Angoa-Pérez $M$, Raisman-Vozari R. Oxidative stress caused by ozone inducess loss of brain repair in the hippocampus of adult rats. Toxicol. Sci. 2009; 13(1): 187197.

Ritz B, Yu F, Fruin S, Chapa G, Shaw GM, Harris JA. Ambient air pollution and risk of birth defects in Southern California. Am. J. Epidemiol. 2002; 155 (1): 17-25.

Rossato JI, Bevilaqua LR, Izquierdo I, Medina JH, Cammarota M. Dopamine controls persistence of long-term memory storage. Science 2009; 325 (5943): 1017-1020. 
Salam MT, Millstein J, Li Y, Lurmann FW, Margolis HLG, Gilliand FD. Birth outcomes and prenatal exposure to ozone, carbon monoxide and particulate matter: results from the children's health study. Environ. Health Perspect. 2005; 113 (111):16381644.

Saldiva PH, Lichtenfels AJ, Paiva PS, Barone IA, Martins MA, Massad E, Pereira JC, Xavier VP, Singer JM, Bohm GM. Association between air pollution due to respiratory diseases in children. Environ. Res. 1994; 65: 218-225.

Saldiva PH, Pope CA, Shwarz J, Dockery DW, Lichtenfels AJ, Salge JM, Barone IA, Bohm GM. Air pollution and mortality in elderly people: a time-series study in São Paulo, Brazil. Arch. Environ. Health 1995; 50: 159-163.

Schleicher $\mathrm{E}$, Wieland $\mathrm{OH}$. Evaluation of Bradford method for protein determination in body fluids. J. Clin. Chem. Clin. Biochem. 1978; 16(9): 533-534.

Schwela D. Air pollution and health in urban areas. Rev. Environ. Health 2000; 15: 13-42.

Sandstead HH, Au W. Zinc. In: Nordberg GF, Fowler BA, Nordberg M, Friberg L. Handbook on the Toxicology of Metals. 3a ed. Estados Unidos da America: Elsevier; 2007. Cap. 47, p. 925-947.

Segalowitz SJ. Public health, brain health, and the dangers of air pollution for neural development. Brain and Cognition 2008; 68: 115-116.

Squire LR, Kandel ER. Memória: da mente às moléculas. Tradução de Carla Dalmaz, Jorge A. Quillfeldt. 1a ed. Porto Alegre: Artmed; 2003.

Sterio DC (1984). The unbiased estimation of number and sizes of arbitrary particles using the disector. J. Microsc., 1984:134: 127-136. 
Suglia SF, Gryparis A, Wright RO, Schwartz J, Wright RJ. Association of black carbon with cognition among children in a prospective cohort study. Am. J. Epidemiol. 2008; 167: 280-286.

Sunyer J. The neurological effects of air pollution in children. Eur. Resp. J. 2008; 32: 535-537.

Tabacova S, Balabaeva L, Little RE. Maternal exposure to exogenous nitrogen compounds and complications of pregnancy. Arch. Environ. Health 1997; 52 (5): 341-347.

Takeda A. Movement of zinc and its functional significance in the brain. Brain Res. Brain Res. Rev. 2000; 34(3): 137-148.

Tang H, Wang Y, Xie L, Mao X, Won SJ, Galvan V, Jin K. Effect of neural precursor proliferation level on neurogenesis in rat brain during aging after focal ischemia. Neurobiol. Aging. 2009; 30(2): 299-308.

Thompson RF. O cérebro: uma introdução à neurociência. Tradução de Sílvia M. Spada. 3a ed. São Paulo: Livraria Santos Editora; 2005.

Tietze F. Enzymatic method for quantitative determination of nanogram amounts of total and oxidized glutathione: applications to mammalian blood and other tissues. Anal. Biochem. 1969; 27: 502-522.

United States Environmental Protection Agency. Air. EUA: EPA; 2009.

Veras MM, Damaceno-Rodrigues NR, Caldini EG, Ribeiro AACM, Mayhew TM, Saldiva PHN, Dolhnikoff M. Particulate air pollution affects the functional morphology of mouse placenta. Biol. Reprod. 2008; 79: 578-584.

Veras MM, Damaceno-Rodrigues NR, Guimarães Silva RM, Scoriza JN, Saldiva PHN, Caldini EG, Dolhnikoff M. Chronic exposure to fine particulate matter emitted by traffic affects reproductive and fetal outcomes in mice. Environ. Res. 2009; 109 (5): 536-543. 
Win-Shwe TT, Yamamoto S, Fujitani Y, Hirano S, Fujimaki H. Spatial learning and memory function-related gene expression in the hippocampus of mouse exposed to nanoparticle-rich diesel exhaust. Neurotoxicology 2008; 29(6): 940-947.

William A. Oxidative stress status: an introduction. Free Radic. Biol. Med. 1991; 10: 173.

Wolfman C, Da Cunha C, Jerusalinsky D, Levi de Stein M, Viola H, Izquierdo I, Medina $\mathrm{JH}$. Habituation and inhibitory avoidance training alter brain regional levels of benzodiazepine-like molecules and are affected by intracerebral flumazenil microinjection. Brain Res. 1991; 548(1-2): 74-80.

Zanchi AC, Venturini CD, Saiki M, Saldiva PHN, Barros HMT, Rhoden CR. Chronic nasal instillation of residual oil fly ash (ROFA) induces brain lipidperoxidation and behavioral changes in rats. Inhal. Toxicol. 2008; 20: 795-800.

Zanchi AC, Saiki M, Saldiva PHN, Barros HMT, Rhoden CR. Hippocampus lipidperoxidation induced by residual oil fly ash inhalation versus cognitive changes: an experimental study. Inhal. Toxicol. 2010; 22(1): 84-88.

Xia $T$, Kovochich $M$, Nel A. The role of reactive oxygen species and oxidative stress in mediating particulate matter injury. Clin. Occup. Environ. Med. 2006; 5(4): 817-836. 


\section{APÊNDICE A}

Regulamento editorial - periódico Inhalation Toxicology.

Artigo submetido à publicação - periódico Inhalation Toxicology (classificação Qualis: A2). 


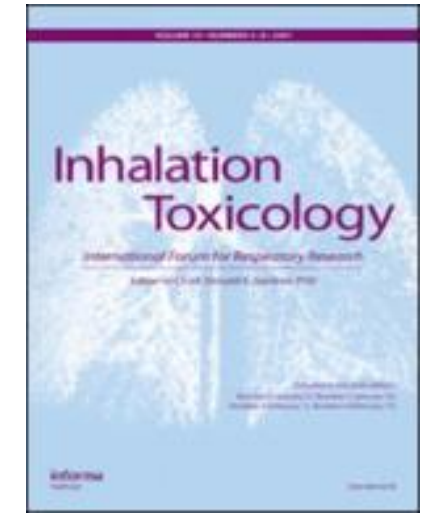

\section{Submission of Manuscripts}

All manuscripts are to be submitted via the Manuscript Central site. Paper manuscripts are not accepted. Authors are responsible for obtaining permission to reproduce copyrighted material from other sources and are required to sign an agreement for the transfer of copyright to the publisher. All accepted manuscripts, artwork, and photographs become the property of the publisher.

\section{Rapid Communications}

Inhalation Toxicology will accept a limited number of highly significant, complete (not a preliminary report), and timely reports that have progressed to the stage at which the science of inhalation toxicology would be significantly advanced by rapid publication. These communications might report discovery of novel effects of inhaled materials or describe novel methodologies that provide insights into responses to inhaled materials. These reports will be designated "Rapid Communications." These communications should be limited to no more than 2 tables and/or 2 figures and be no more than 12 double-spaced, type-written manuscript pages. Rapid Communications, if found acceptable for publication, will have a facilitated publication time appearing in the journal approximately 3 months after acceptance by the Editorial Office. An original and two copies of the manuscript plus a disk should be sent to the Editor's Office with a letter noting the significance of the contribution for a rapid communication.

\section{Letters to the Editor}

These will be accepted for publication subject to the Editor's approval, provided that the content deals with papers published in Inhalation Toxicology and that the comments are of scientific value. Letters should be received within 2 months of mailing of the journal and should be no longer than 250 words in length. Introduction of new data will not be permitted. Each 
letter will be submitted to the author(s) of the original paper in order that any reply may be published simultaneously with the Letter to the Editor.

\section{Preparation of Manuscripts}

All parts of the manuscript should be typewritten, double-spaced, with margins of at least one inch $(2.5 \mathrm{~cm})$ on all sides. Number each line of text as well as each manuscript page consecutively throughout the paper. Authors should also supply a shortened version of the title suitable for the running head, not exceeding 50 character spaces. Each article should be summarized in an abstract of not more that 250 words. Avoid abbreviations, diagrams, and reference to the text within the abstract. The following main sections are suggested as subdivisions of a paper:

\section{Introduction}

Should explain the purpose of the study, cite relevant work, and describe objectives.

\section{Method}

The work and methodology used should be described and referenced.

\section{Results}

Should include a description of what was done, how the experiments were conducted, the analysis of data collected, and the significance of results.

\section{Discussion and Conclusions}

The findings should be related to existing knowledge in the area and the importance of the contribution of this study to the advancement of the field; the conclusion should be based on the experimental data obtained.

\section{References}

Should be alphabetized by author and compiled in a separate section at the end of the manuscript. Cite in text by author and date. Follow the format for scientific references listed in The Chicago Manual of Style, 14th ed., Chicago: University of Chicago Press. Reference lists must be complete, including, for journal articles: initials and surnames of all authors, date, article title, abbreviated journal title, volume number, and inclusive page numbers; for book references: initials and surnames of all authors, date, chapter title, book title, editors, volume number, inclusive page numbers, city of publication, and publisher. 


\section{Illustrations}

Illustrations submitted (line drawings, halftones, photos, photomicrographs, etc.) should be clean originals or digital files. Digital files are recommended for highest quality reproduction and should follow these guidelines:

- 300dpi or higher

- sized to fit on journal page

- EPS, TIFF, or PSD format only

- submitted as separate files, not embedded in text files

Color illustrations will be considered for publication; however, the author will be required to bear the full cost involved in their printing and publication. The charge for the first page with color is $\$ 1000.00$. The next three pages with color are $\$ 500.00$ each. A custom quote will be provided for color art totaling more than 4 journal pages. Good quality color prints or files should be provided in their final size. The publisher has the right to refuse publication of any artwork deemed unacceptable.

\section{Tables and Figures}

Tables and figures should not be embedded in the text, but should be included as separate sheets or files. A short descriptive title should appear above each table with a clear legend, and any footnotes suitably identified below. All units must be included. Figures should be completely labeled, taking into account necessary size reduction. Captions should be typed, doublespaced, on a separate sheet. All original figures should be clearly marked in pencil on the reverse side with the number, author's name, and top edge indicated.

\section{Proofs}

One set of proofs is sent to the corresponding author. Proofs should be carefully checked and returned within 48 hours.

\section{Reprints}

Reprints of an individual article may be ordered from Informa Healthcare by accessing the link powered by Rightslink, a division of Copyright Clearance Center (CCC) at the time article proofs are viewed. Adiscount on reprints is available to authors who order before print publication. 


\section{Declaration of Interest}

It is the policy of all Informa Healthcare, to adhere in principle to the Conflict of Interest policy recommended by the International Committee of Medical Journal Editors (ICMJE). (http://www.icmje.org/index.html\#conflict)

All authors must disclose any financial and personal relationships with other people or organisations that could inappropriately influence (bias) their work. It is the sole responsibility of authors to disclose any affiliation with any organisation with a financial interest, direct or indirect, in the subject matter or materials discussed in the manuscript (such as consultancies, employment, paid expert testimony, honoraria, speakers bureaus, retainers, stock options or ownership, patents or patent applications or travel grants) that may affect the conduct or reporting of the work submitted. All sources of funding for research are to be explicitly stated. If uncertain as to what might be considered a potential conflict of interest, authors should err on the side of full disclosure.

All submissions to the journal must include full disclosure of all relationships that could be viewed as presenting a potential conflict of interest. If there are no conflicts of interest, authors should state that there are none. This must be stated at the point of submission (within the manuscript after the main text under a subheading "Declaration of interest" and where available within the appropriate field on the journal's Manuscript Central site). This may be made available to reviewers and will appear in the published article at the discretion of the Editors or Publisher.

If no conflict is declared, the following statement will be attached to all articles:

Declaration of interest: The authors report no conflicts of interest. The authors alone are responsible for the content and writing of the paper.

The intent of this policy is not to prevent authors with these relationships from publishing work, but rather to adopt transparency such that readers can make objective judgements on conclusions drawn.

\section{NIH Public Access Policy}

In consideration of the National Institutes of Health $(\mathrm{NIH})$ Public Access Policy, Informa Healthcare acknowledges that the broad and open dissemination of $\mathrm{NIH}$-funded research results may benefit future scientific and medical research. Because we value the current and future contributions our journals make to the scientific body of knowledge, we have made certain that our policies accommodate those authors who wish to submit to PubMed Central. 
Informa Healthcare's position with respect to public access to NIH-funded work published in Informa Healthcare journals is as follows:

- Informa Healthcare authors may voluntarily submit their funded work to PubMed Central after a 12 month embargo period.

- "Funded work" shall be defined as the final, peer-reviewed manuscript that is accepted by the Editor in Chief of the journal. This manuscript must not be altered by Publisher's copyediting and typesetting services.

- This embargo period begins the day the work is published online at www.informaworld.com 
Pre and post-natal exposure to ambient level of air pollution impairs memory of rats: the role of oxidative stress

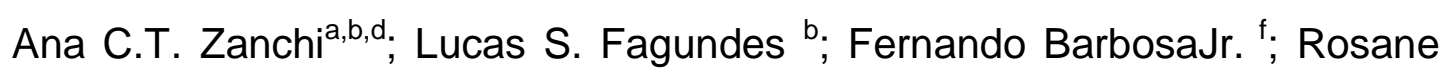

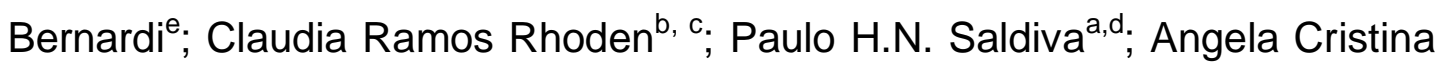
do Valle ${ }^{d}$

a Laboratory of Experimental Air Pollution. Department of Pathology, School of Medicine, University of São Paulo, SP, Brazil

b Laboratory of Oxidative Stress and Atmospheric Pollution, Health Basic Sciences Department, Federal University of Health Sciences of Porto Alegre (UFCSPA), RS, Brazil

${ }^{c}$ Pos-Graduate Course in Medical Sciences. Federal University of Health Sciences of Porto Alegre, (UFCSPA), RS, Brazil.

${ }^{d}$ Pos-Graduate Course in Physiopathology. School of Medicine, University of São Paulo (USP). São Paulo, SP, Brazil.

e Pharmacology Division, Basic Health Sciences Department, Federal University of Health Sciences of Porto Alegre, (UFCSPA), RS, Brazil.

${ }^{f}$ Trace Elements Lab - Faculty of Pharmaceutical Sciences of Ribeirão Preto - University of São Paulo (USP), Ribeirão Preto, Brazil

Correspondence

Ana Claudia Tedesco Zanchi

Rua Gonçalves Ledo, 129. Partenon, Porto Alegre

RS - Brazil - Zipcode: 90610-250

e-mail: aczanchi@gmail.com 


\section{Abstract}

The aims of this study were to evaluate whether air pollution during pre-natal and post-natal phases change habituation and short-term discriminative memories and if oxidants are involved in this process. Rats were divided into 4 groups ( $n=12$ / group): control: pre and post-natal exposure until adulthood in filtered air; pre-natal: pre-natal period in non-filtered air until PND21 and post-natal in filtered air until adulthood; post-natal: pre-natal in filtered air until PND 21 and post-natal in non-filtered air until adulthood; pre-post: pre and post-natal in non-filtered air. After 150 days spontaneous recognition object test was applied to evaluate short-term discriminative and habituation memories. Rats were euthanized; blood was collected for metal determination; cortex dissected for oxidative stress evaluation. There was a significant increase in malondihaldeyde levels in the pre-post group when

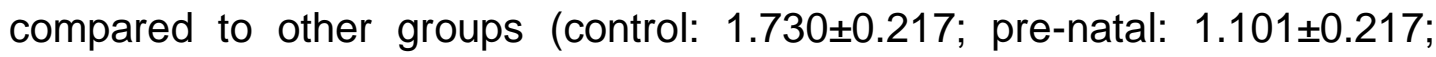
post-natal: $1.014 \pm 0.300$ pre-post: $5.978 \pm 1.920 \mathrm{nmol} \mathrm{MDA} / \mathrm{mg}$ total proteins; $P=0.007)$.Pre-post group presented a significant decrease in short-term discriminative (control: $0.603 \pm 0.106$; pre-natal: $0.669 \pm 0.0666$; post-natal: $0.374 \pm 0.178$; pre-post: $-0.00631 \pm 0.106 \mathrm{sec} ; \mathrm{P}=0.006$ ) and an improvement in habituation memories when compared to other groups. Therefore, exposure to air pollution during both those periods impairs short-term discriminative memory and cortical oxidative stress may mediate this process.

Key words: air pollution, memory, oxidative stress. 


\section{Introduction}

Air pollution is an emergent public health problem. Clinical and preclinical studies indicate a positive correlation between the levels of pollutants and human health damage $[40,41]$. Prenatal exposure to air pollutants induces low birth weight, decreases newborn height and increases the risk of miscarriage in the first three months of pregnancy $[15,20,28,52]$. Moreover, Perera et al. (2009) [36] have demonstrated that continuous exposure of pregnant women to aromatic polycyclic hydrocarbons caused a decrease in their children IQ.

Recently, Calderón-Garcidueñas et al. have shown air pollution as one of the factors that determine prefrontal cortex brain inflammation found in children with sudden death [9] or with signs of cognitive impairment [10]. Other epidemiological studies have shown that the exposure to environmental lead is an important risk factor for Attention Deficit Hyperactivity Disorder [Needham, 2005]. Moreover, Zanchi et al. [54] have shown that toxic particles, administered through the respiratory route, induce oxidative stress in the striatum and cerebellum and a decreased motor activity in adult rats although the one month inhalation of residual oil fly ash did not modify the rats habituation to open field test [53].

Therefore, air pollution challenges the CNS to create adjustment mechanisms in order to prevent damages. Regarding this, learning and memory abilities are essential tools and the higher these abilities the better chance of survival [45]. Habituation, characterized by the decline of the 
behavioral reaction induced through the repeated presentation to a stimulus, is a kind of memory closely related to the interaction of the organisms with the environment $[45,49]$. The study of air pollution effects on habituation parameters is justified since this memory helps to protect the individuals from irrelevant stimuli and allows directing the attention to meaningful events [39, 42]. Additionally, the evaluation of pollutant effects in cognition as short and long term memory is important as these kinds of memories are responsible for one's knowledge and autobiography [45].

The aim of this research paper was to study memory changes determined by air pollution exposure during pre-natal and early post-natal phases and if these changes were dependent of oxidants. The Spontaneous non-matching-to-sample recognition test (SORT) was used because such paradigm allows investigating discriminative memory and habituation. In this context, the term discriminative memory refers to the ability of discriminating between familiar and non-familiar objects which could experimentally be represented as a form of episodic memory dependent on cortical circuits. Habituation is quantified by the difference of time spent in exploring both objects between sessions. This kind of memory is more automatic and classified by some authors as a form of procedural memory dependent on sub-cortical structures. 


\section{Materials and Methods}

\subsection{Animal care}

This study was approved by the review board for human and experimental studies of the University of the São Paulo School of Medicine (CAPPesq-0067/07) and by the Ethical Committee for Research of the Federal University of Health Sciences of Porto Alegre (CPA 084/03). The study was carried out in accordance with international and national guidelines for animal welfare [18].

\subsection{Animals}

Male Wistar rats $(n=8), 45$ days old, from the Biological Research Institute Facility of Rio Grande do Sul, Brazil, were hold in polluted or clean chambers up to 72 days old, in other words, one spermatogenesis cycle. Females $(n=40)$ were from the same Facility and lived in both chambers for 15 days to adjust to the environment before mating. Inside the chambers, six rats per cage, classified by sex, were housed in plastic cages $(47 \mathrm{~cm} \times 34 \mathrm{~cm}$ x $18 \mathrm{~cm})$, at controlled temperature $\left(22^{0}+2^{0} \mathrm{C}\right), 12$-hour-light/dark cycles (light from 7:00 a.m. to 7:00 p.m.), food (conventional laboratory diet Supra-lab, Alisul Alimentos S.A., Brazil) and_water were available ad libitum.

After the adjustment of the rats, one male mated with five females for

13 days inside both chambers. Pregnancy was confirmed by visual inspection. Approximately, 18 females from filtered and 20 females from non- 
filtered chambers were pregnant and separated from males. On gestational days, two female rats were left undisturbed in each cage. At delivery ( $1^{\circ}$ day), pups were weighted. Then, the number of neonatal deaths, total number of rats (both gender) and the number of animals separated by gender were counted. Later, on the $7^{\text {th }}$ day, offsprings were weighed again; during the time of exposure in both chambers, the development of the animals followed two parameters: essential time (days) for the emergence of the first hair and opening their eyes. Puppies from six litters were weaned on the $21^{\text {st }}$ postnatal day (PND21) and segregated by gender.

\subsection{Site of exposure}

The experiments were carried out in exposure chambers located in the garden of the Federal University of Health Sciences of Porto Alegre, south of Brazil, which is located on a high traffic density avenue where the source of air pollution is predominantly automotive.

\subsection{Exposure Chambers}

Two $11.8 \mathrm{~m}^{3}$ exposure chambers, covered with a plastic ultraviolet protection film, were built on a metallic structure, assembled in the courtyard of the University in Porto Alegre. The air of each exposure chamber was supplied by a filtration air unit at a flow rate of $33 \mathrm{~L} / \mathrm{min}$. The filtered air (FAC) unit consisted of two pre-filters (PP-30 and pleat pre-filter of 18"), chemical 
(Puracarb $\circledast$ and PK-12) and HEPA filters stages (Purafil ${ }^{\circledR}$ side access TAG B07-8338, Borges-Katayama, SP, Brazil). The PP-30 had a 30\% average efficiency and the pleat pre-filter of $18 ", 60 \%$. average efficiency These prefilters were mechanical barriers to remove the dust and avoid obstruction of the surface of the pores of pellets in the next stage of this unit. The next stage consisted of Puracarb® (activated coal) and PK-12 in "V" which is made from ABS plastic, that contains Purafil@ CHEMI SELECT (alumen impregnated with potassium permanganate). Moreover, there were two stages of HEPA PH-97 which had a $99.97 \%$ highest efficiency (BorgesKatayama, SP, Brazil). Puracarb® presents the neutralization capacity to $\mathrm{H}_{2} \mathrm{~S}, \mathrm{SO}_{2}, \mathrm{Cl}_{2}$ of $20 \%, 5 \%$ and $8 \%$, respectively and the Purafilß CHEMI SELECT, the neutralization capacity to $\mathrm{H}_{2} \mathrm{~S}, \mathrm{SO}_{2}, \mathrm{NO}$, and $\mathrm{O}_{3}$, of $14 \%, 7 \%$, $4.9 \%$ and $90 \%$, correspondingly (Borges-Katayama, SP, Brazil). The HEPA filters retain $99.97 \%$ of dust and $\mathrm{PM}_{2.5}$, besides the microorganisms (BorgesKatayama, SP, Brazil). The non-fitered (NFAC) air chamber presented only the mechanical filter. Additionally, the pressure inside the chambers did not

exceed the atmospheric pressure by more than $3 \mathrm{~cm} \mathrm{H}_{2} \mathrm{O}$. Approximately, $1,960 \mathrm{~L} / \mathrm{h}$ of air flow was provided by a fan assembled between the filtration unit outlet and the chamber inlet (figure 1).

\subsection{Pollutant determination}

Samples were taken dayly to measure $\mathrm{PM}_{2.5}$ concentrations in the chambers during the exposure period. The 24-hour concentration was determined gravimetrically [26] using Harvard impactor (Air Diagnostics and 
Engineering Inc., Harrison, ME, 151, USA) at a flow rate of 10L/min and equipped with polycarbonate filters. Results were expressed as $\mu \mathrm{g} / \mathrm{m}^{3}$. The total monthly $\mathrm{PM}_{2.5}$ mass from February to June 2008 is shown in table 1 [26]. During the exposure period, humidity in Porto Alegre was between 50 and $95 \%$ and temperature, between 10 and $25^{\circ} \mathrm{C}$ [26].

\subsection{Experimental design}

Male rats, 21 days old, from each group (filtered and non-filtered) were distributed in 4 experimental groups according to the following protocol (12 animals per group): 1) control: - pre and post-natal exposure until adulthood in filtered air; 2) pre-natal: pre-natal period in non-filtered air until PND21 and post-natal in filtered air until adulthood; 3) post-natal: pre-natal period in filtered air until PND 21 and post-natal period in non-filtered air until adulthood; 4) pre-post: pre and post-natal periods in non-filtered air.

For the next 150 days (February to June 2008) rats were exposed or not to air pollution 24 hours daily inside the chambers. Rats were kept in plastic cages $(47 \mathrm{~cm} \times 34 \mathrm{~cm} \times 18 \mathrm{~cm}), 6$ animals per cage at controlled temperature $\left(22^{0}+2^{0} \mathrm{C}\right), 12$-hour-light/dark cycles (light from 7:00 a.m. to 7:00 p.m.), food (conventional laboratory diet Supra-lab, Alisul Alimentos S.A., Brazil) and water were available ad libitum.

On the $151^{\text {st }}$ day, animals ( $\mathrm{n}=12$ per group) were submitted to the behavioral test. At the end of the experiment, animals were euthanized by 
decapitation and troncular blood was collected in order to analyze trace elements. The brain was removed and the cortex was dissected, immediately frozen and stored in a $-80^{\circ} \mathrm{C}$ freezer for oxidative stress evaluation.

\subsection{Spontaneous non-matching-to-sample recognition test (SORT)}

The SORT was applied in a gray-painted wooden test box $(60 \times 45 \times$ $45 \mathrm{~cm})$ and the floor was covered with paper that was removed between each session. Two sets of different objects, heavy enough to prevent displacement, were used. The behavioral procedure was always conducted from 9:00 a.m. to 1:00 p.m. On the first day of test, the rats were placed in the middle of the box for 3 min (environmental habituation session), without any objects. The rats were removed from the box and returned to their home cages. Twenty four hours later, the rats were placed in the middle of the box, facing two identical objects arranged in the opposite side and allowed to explore them for 3 min and then returned to their cages. Forty five minutes later, the rats were reintroduced into the box for the test session where the objects had been replaced by one clean familiar object and one novel or nonfamiliar object and the animals were allowed to explore both objects for 3 min $[2,5]$. The two sessions were recorded in a DVD recorder. The videos were analyzed by a blind trained observer through direct computer keyboard input BASIC-written software (Kevin Willioma, KD Ware Computer, and Boston, MA, modified by Thomas Vatne). 
Sniffing the objects from a distance of less than $2 \mathrm{~cm}$ or touching them with the nose were the behavioral parameters used to determine the discrimination index. The discrimination index was determined by the ratio between the difference of time exploring the novel and the familiar objects and the total time spent in sniffing both objects during the choice session (novel - familiar/novel + familiar). Habituation to the test environment was obtained by the difference of time sniffing both objects in the training session and in the test session $[2,5]$.

\subsection{Oxidative stress analysis}

\subsubsection{Tissue preparation}

Dissected cortex was homogenized in 9 volumes of $120 \mathrm{mM} \mathrm{KCl}, 30$ $\mathrm{mM}$ sodium phosphate buffer $(\mathrm{pH} 7.2)$ added with protein inhibitors $(1 \mu \mathrm{g} / \mathrm{ml}$ leupeptin, $1 \mu \mathrm{g} / \mathrm{ml}$ aprotinin, $10 \mu \mathrm{g} / \mathrm{ml}$ soybean trypsin inhibitor, $1 \mu \mathrm{g} / \mathrm{ml}$ pepstatin, and $0.5 \mathrm{mM}$ PMSF). The suspension was centrifuged at $600 \mathrm{~g}$ for $10 \mathrm{~min}$ at $0-4^{0} \mathrm{C}$ to remove nuclei and cell debris. The pellets were discarded and the supernatants were used as homogenates [31].

\subsubsection{Determination of TBARS - Lipid Peroxidation}

The determination of lipid peroxidation (LP) was performed using the thiobarbituric acid reactive substances (TBARS) method [8], as a measurement for oxidative stress. Homogenates were precipitated with $10 \%$ 
TCA, centrifuged, and incubated with thiobarbituric acid (Sigma Chem. Co., St. Louis, USA) for 15 minutes at $100^{\circ} \mathrm{C}$. TBARS were extracted using butanol $(1: 1 ; \mathrm{v} / \mathrm{v})$. After centrifugation, the absorbance of the butanol layer was measured at $535 \mathrm{~nm}$. The concentration of TBARS was expressed in nmol malondialdehyde (MDA)/ mg of total proteins [8, 31]. MDA standard was prepared from 1.1.3.3-tetramethoxypropane. Protein concentration was measured using the Bradford Protein Assay at $595 \mathrm{~nm}$ [43] considering bovine serum albumin $(1 \mathrm{mg} / \mathrm{mL})$ as standard.

\subsubsection{Determination of Superoxide Dismutase (SOD)}

SOD activity was performed according to Marklund and Marklund [27]. The reaction consists in inhibiting the pyrogallol autoxidation by SOD activity. In a cuvet, $930 \mu \mathrm{l}$ of TRIS buffer (TRIS $50 \mathrm{mM}$, EDTA $1 \mathrm{mM}, \mathrm{pH} 8.2$ ), $4 \mu \mathrm{l}$ of catalase $(30 \mu \mathrm{M})$ and $50 \mu \mathrm{l}$ of homogenate were added and mixed. After, pyrogallol (24mM in $\mathrm{HCl} 10 \mathrm{mM}$ ) was added and SOD activity determined at $25^{\circ} \mathrm{C}$ at $420 \mathrm{~nm}$ in 60 and $120 \mathrm{~s}$. One unit of SOD is defined as the quantity of enzyme that is capable of inhibiting $50 \%$ of the reaction. The results were expressed in Units of SOD/ mg total proteins.

\subsubsection{Determination of Catalase (CAT)}

Catalase concentration was performed accordingly to Aebi [1]. In a quartzo cuvet, $30 \mu \mathrm{l}$ of homogenate, $2865 \mu \mathrm{l}$ of phosphate buffer $(50 \mathrm{mM}, \mathrm{pH}$ 7.4) were mixed. Afterwards, $105 \mu \mathrm{l}$ of hydrogen peroxide $(0.01 \mathrm{M})$ was 
added and mixed. The decomposition of hydrogen peroxide by catalase activity was determined at $25^{\circ} \mathrm{C}$ at $240 \mathrm{~nm}$ (UV) for $120 \mathrm{~s}$. The results were expressed in $\mathrm{pmol} / \mathrm{mg}$ of total proteins.

\subsubsection{Total gluthatione (tGSH)}

The total gluthatione (glutathione reduced + glutathione disulfide) was assayed using an available glutathione kit at $412 \mathrm{~nm}$ (Sigma CS0260, Saint Louis, Missouri, USA), following Tietze [50] the protocol. The measurement of tGSH consists in a kinetic assay with catalytic amounts (nmoles) of GSH causing a continuous reduction of 5, 5'- dithiobis (2-nitrobenzoic acid) (DTNB) to 5 - thio -2- nitrobenzoic acid (TNB). The results were expressed in $\mathrm{nmol} / \mathrm{mg}$ of total proteins.

All measurements were carried out in a Perkin-Elmer Lambda 35 spectrophotometer (Perkin-Elmer do Brasil, SP, Brazil).

\subsubsection{Index of oxidative stress}

The index of oxidative stress was calculated by the ([SOD]/[CAT]) rate.

\subsubsection{Trace elements determination}

Blood samples were analyzed for trace elements determination according to the method proposed by Batista et al. (2009) [4]. Briefly, $100 \mu \mathrm{l}$ of blood were diluted $1: 50 \mathrm{v} / \mathrm{v}$ in a solution containing $0.01 \%(\mathrm{v} / \mathrm{v})$ Triton® X100 and $0.05 \%(\mathrm{v} / \mathrm{v}) \mathrm{HNO}_{3}$. After that, analysis were carried out with an 
inductively coupled plasma mass spectrophotometer equipped with a reaction cell (DRC-ICP-MS ELAN DRC II, Perkin Elmer, SCIEX, Norwalk, CT, USA) operating with high purity argon (99.999\%, Praxair, Brazil) and ammonium as the reaction gas $(99.999 \%$. Praxair, Brazil). Subsequent experiments were performed in order to select the internal standard. Rhodium (Rh), iridium (Ir) and $\mathrm{Y}$ (Yttrium) were evaluated as internal standards. Rhodium (103) exhibited better or equal performance compared to other internal standards, regarding precision and accuracy for the determination of As, $\mathrm{Cd}, \mathrm{Co}, \mathrm{Cr}, \mathrm{Mn}, \mathrm{Pb}, \mathrm{Se}, \mathrm{TI}$ and $\mathrm{V}$ and iridium (193) for $\mathrm{Cu}$ and $\mathrm{Zn}$ determinations in blood reference samples (QMEQAS07B03 and QMEQAS07B06). Then, all blood samples and matrix-matching standards were prepared containing $10 \mu \mathrm{gL}^{-1} \mathrm{Rh}$ or Ir. Method detection limits for ${ }^{114} \mathrm{Cd}$, ${ }^{63} \mathrm{Cu},{ }^{55} \mathrm{Mn},{ }^{208} \mathrm{~Pb},{ }^{82} \mathrm{Se}$ and ${ }^{64} \mathrm{Zn}$ were 3.0, 280, 9.0, 3.0, 264, $800 \mathrm{ng} / \mathrm{L}$, respectively. Results were expressed in $\mu \mathrm{g} / \mathrm{L}$ blood [4].

\subsection{Statistical Analysis}

Results were expressed as mean \pm standard error of the mean (SEM), unless otherwise stated. Student $t$ test was used to compare pups development parameters between both chambers. One Way Analysis of Variance (ANOVA) followed by post-hoc Student-Newman-Keuls test was used to compare means of MDA, CAT, SOD, tGSH, [SOD]/[CAT], trace elements blood concentrations and behavioral parameters among control, pre-natal, post-natal and pre-post groups. Two Way ANOVA followed by all pair wise multiple comparison Procedures (Student-Newman-Keuls test) was 
used to evaluate the impact of birth environment (until PND21) and its changes on habituation and discrimination (novel object - familiar object/novel object + familiar object ratio) indexes as dependent variables. All statistical analysis were performed using Sigma-Stat 3.11 Software (Systat Software Inc. 2004, Point Richmond, CA, USA). The level of significance was set at $5 \%$. 


\section{Results}

In table 1, we presented the litters development parameters. There were no statistically significant differences in development parameters even though the pregnant rats had lived in a non-filtered air chamber.

In tables 2 and 3 , the monthly total mass and trace elements concentration of $\mathrm{PM}_{2.5}$ during the exposure period (February to June, 2008) were presented, respectively.

As demonstrated in table 4 there was an increase in Cd concentration when comparing post-natal to control and pre-post to control groups $(P=0.005)$. Furthermore, there was a statistically significant increase in trace elements concentration $(\mathrm{Cu}, \mathrm{Se}, \mathrm{Zn})$ in pre-natal group $(\mathrm{P}<0.05)$ when compared to control, post-natal and -pre-post (table 4).

The oxidative stress level, an imbalance between oxidant and antioxidant processes, was evaluated by the cortical concentrations of MDA, SOD, CAT and tGSH. A significant increase in MDA levels was found in the pre-post group when compared to control, pre-natal and post-natal groups $(P=0.007$; figure $2 A)$. Accordingly, the index of oxidative stress was lower in pre-post when compared to pre-natal group $(P=0.046)$ (figure $2 B)$. A statistically significant decrease in the tGSH levels was found in the postnatal group when compared to control, pre-natal and pre-post groups $(P=0.003$; figure $2 C)$.

The results of the SORT test are shown in figure 3 . The habituation was higher in the pre-post group when compared to control, pre-natal and 
post-natal groups. Rats from pre-post group showed a significant increase $(P=0.001)$ in total exploration time of both objects in the training session when compared to total exploration time in the test session (habituation test) (figure $3 \mathrm{~A}$ ). In terms of habituation index, there was a significant interaction between the place of birth and the change of environment $(P=0.035)$. The pre-post group showed a significant decrease $(P=0.006)$ in the discrimination index of objects when compared to control, pre-natal and post-natal groups (figure 3B). 


\section{Discussion}

In the current study, it was shown that pre and post-natal (first childhood) exposure to environmental air pollution (tables 2 and 3) induces an increase in cortex oxidative stress (figures $2 \mathrm{~A}, 2 \mathrm{~B}$ and $2 \mathrm{C}$; tables 4 and 5 ) as well as an impairment of short-term discriminative memory (figure 3B). However, it was not observed any differences in the litters developmental parameters.

There were no differences between litters from FAC and litters from NFAC (figure 1 and table 1) related to all development parameters. In the literature, Veras et al. (2008) [51] demonstrated that animals exposed to PM in the city of São Paulo, Brazil, presented lower weight after delivery. Lichetenfels et al (2007) [25] demonstrated, in the same city, that mice females were the majority when compared to the number of males born in polluted environment. However, the animals in this study did not present lower weight after delivery and any differences in development or in sex ratio. Clearly, the chemical composition of air pollution influenced these biological effects.

Exposure to metals during organogenesis may give rise to fetal anomalies, and exposure during other periods of development may result in embryo or fetal lethality or other developmental effects. Data on the concentration of cadmium in maternal blood, placental and fetal blood indicate that $\mathrm{Cd}$ accumulates in the placenta, reaching the human fetus in detectable amounts. Several studies in rats and mice indicate that $\mathrm{Cd}$ may be fetotoxic before and during gestation. This fetotoxicity is most often 
manifested as reduced fetal weight and neurobehavioral toxicity (Nordberg et al. 2007a) [32]. The effects produced by metals depend on the timing and duration of exposure, on their distribution and accumulation in various organs such as the nervous system, and on the ability to interfere with specific developmental processes. Effects may be enhanced by biochemical, physiological and anatomical changes occurring during development, which may result in a modified metabolism of the metal (or trace element) itself. Neurodevelopment impairment in humans may range from serious mental retardation and other overt clinical syndromes to subclinical deficits as sensory, motor and cognitive impairment that are difficult to identify [3]. In rats treated with $\mathrm{Cd}$ during pregnancy, lactation and for 8 weeks after weaning (at doses ranging from 3, 5, $14 \mathrm{mg} / \mathrm{Kg}$ ), there were behavioral and neurotoxicological changes. Open-field behavior and spontaneous and evoked cortical activity were investigated at the age of 12 weeks. Vertical exploration activity and open-field center exploration were increased; spontaneous and evoked electrophysiological variables showed dosedependent and generation-dependent changes, thus indicating that low-level of inorganic Cd can affect some nervous system functions [3].

It is known that oxidative stress is potentially able to trigger brain damage during any stage of its development, which is demonstrated by a diversity of pathological manifestations [47]. Veras et al. (2008) [51] have shown that gestational exposure to particulate urban air pollution was associated with reduced volumes, calibers and surface areas of maternal placenta blood spaces and increased fetal capillary surfaces and diffuse 
conductance. Damasceno-Rodrigues et al. (2009) [14] have shown a positive interaction between pre and post-natal exposure to air pollution with MDA levels in heart, indicating that there is a reinforcement of the deleterious effects of pollutants on myocardial cells.

Humans and animals utilize an antioxidant defense system composed of the enzymes CAT, copper-zinc and manganese superoxide dismutases (CuZnSOD and MnSOD) and glutathione peroxidase (GPx) as well as nonenzymatic substances like reduced glutathione (GSH) to neutralize the biological oxidative damage and protect the organs by scavenging the reactive oxygen species (ROS) [21]. Khan and Black (2003) [22] have demonstrated that rat brain protein levels of GSH, CuZnSOD, MnSOD, total SOD as well as GPx and CAT activity increase at the end of gestation and in newborns up to PND21 (post-natal day 21). These developmental-induced modifications are parallel to the metabolic demand and to free radical generation during myelination and synaptogenesis, which occur at approximately PND10-14 days in the mouse brain. Nevertheless, some studies related a decrease of antioxidant endogenous system responses to aging [24] exacerbated by the interaction of aging and restraint stress [11]. In this study, the pre-post group showed a significant increase in MDA levels (figure 2A). A decrease in tGSH concentration could also be observed when post-natal to control, pre-natal and pre-post groups were compared suggesting a consumption of tGSH by the antioxidant enzymatic system when rats were moved from filter to non-filtered environment. This group presented an increase in tGSH levels and possibly, there was a reversal 
effect of biochemical parameters as these animals final environment was filtered (clean air) (figure 2C). Oxidative index is the ratio between [SOD] and [CAT]. The different results of oxidative index from pre-natal and pre-post groups may be explained by the model of oxidative stress levels [56]. The index of oxidative stress was lower in pre-post when compared to the prenatal group, which demonstrates the consumption of SOD and catalase enzymes to protect against oxidative damage (level 2 of oxidative stress) (figure 2B). Furthermore, oxidative stress index from the pre-natal group proved that these rats antioxidant system adjusted to the oxidative stress state (level 1 of oxidative stress) and reinstated the balance between the oxidants and antioxidants substances. Possibly, the pre-post group will present, after a period of time, an increase in oxidative stress index because rats might adjust themselves to the oxidative stress state. Therefore, the results show that the change from a pollutant to a non-pollutant air (pre-natal group) environment reversed the biochemical changes induced by reactive oxygen species (ROS), as shown by the recovery to normal level of MDA.

Some of non-essential toxic metals such as cadmium (Cd) and lead $(\mathrm{Pb})$ are adsorbed by the surfaces of particulate matter (PM) [33]. Their sources are predominantly automotive [17]. Chow et al. (2008) [13] showed the toxic properties of this metal in red blood cells during zebrafish embryonic brain development, in which $\mathrm{Cd}$ increased MDA levels and induced neurotoxicity by impairing neurogenesis, neuronal differentiation and axonogenesis. Cadmium is also involved in apoptotic cell death of endothelial cells of blood brain barrier (BBB) through the depletion of antioxidant 
substances and enhanced lipid peroxidation [44]. In the present study, higher blood levels of Cd were found in the post-natal group, maybe because of the inhalation of $\mathrm{Cd}$ adsorbed in the PM surface until adult age. It was also found significantly higher blood levels of $\mathrm{Cd}$ in the pre-post group that may reflect the combination of the direct exposure to $\mathrm{Cd}$ on primitive nervous tissue which seems possible at early stages of gestation, before blood-brain barrier is established [33]. Furthermore, Takeda (2000) [48] showed that BBB is in development 2 weeks and 4 months after delivery in rats and humans, respectively, which permits that toxic substances to pass to CNS. The inhalation of $\mathrm{Cd}$ adsorbed in the PM surface during life time was also influenced by an indirect pathway (through systemic inflammation) the CNS $[34,35]$.

Essential metals such as $\mathrm{Cu}, \mathrm{Se}, \mathrm{Mn}$ and $\mathrm{Zn}$ (table 5) are important cofactors to the antioxidant enzyme system. Zinc is a cofactor for ZnCuSOD. This enzyme catalyzes the dismutation of superoxide anion resulting in hydrogen peroxide and oxygen. Selenium is a cofactor for CAT and GPx. Both enzymes catalyze the next step of this biochemical pathway by breaking the hydrogen peroxide and generating water and oxygen [19]. In the present study, it was observed that the animals exposed to air pollution in the prenatal period and then moved into a non-polluted environment presented significant higher blood concentration of $\mathrm{Zn}$ and Se. Cd may interfere in essential metals metabolism. The inhibition of SOD activity might be a consequence of an interaction between $\mathrm{Cd}$ and $\mathrm{Zn}$ in SOD molecules. $\mathrm{Cd}$ might be able to occupy the site of $\mathrm{Zn}$ in the CuZnSOD, creating an inactive 
form of this enzyme [12]. In the same way, reduced (GSH) glutathione is essential for the antioxidant defense of the organism. An atom of $\mathrm{Cd}$ conjugated with two molecules of GSH is excreted by the bile that reduces the antioxidant capacity of the same [38]. Cd also interacts with Se and disrupts glutathione peroxidase activity [12] (tables 4 and 5). Moreover, Cd could displace $\mathrm{Fe}$ and $\mathrm{Cu}$ from storing proteins such as ferritin and ceruplasmin causing ROS increase through Fenton reaction $\left(\mathrm{Fe}^{+2}\right.$ or $\mathrm{Cu}^{+1}$ reduced reacts with hydrogen peroxide which results in hydroxyl radical and $\mathrm{Fe}$ or $\mathrm{Cu}$ oxidized $-\mathrm{Fe}^{+3}$ or $\mathrm{Cu}^{+2}$ ). Even though $\mathrm{Cd}$ interferes in essential metals metabolism, that metal induces the mellathionin synthesis. This protein stores $\mathrm{Cd}$, which might decrease its bioavaliability in the CNS [12, 32, 33].

There are evidences showing that the CNS is a target of air pollution induced damage $[9,10,46]$. Recently, it has been demonstrated that chronic residual oil fly ash (ROFA) instillation promoted lipid peroxidation in striatum and cerebellum of adult rats. This damage was protected by $n$-acetylcysteine (NAC) treatment [54]. It has also been verified that ROFA instillation decreased animal' motor activity and that NAC did not reverse this effect [54]. The findings related to the evaluation of memory by SORT corroborate the idea that the exposure to air pollution modifies some of the brain functions. This test was originally described as a test of working memory [16] but it has been modified to study mutant mice, aging deficits, early developmental influences, nootropic manipulations, teratological drug exposure and novelty seeking [6]. A significant impairment of the short-term discriminative memory 
was seen only in the pre-post group. This finding suggests that the exposure to air pollution during the animal lifetime is necessary in order to determine a significant impairment of short-term discriminative memory because the animal exposure during only pre or post-natal period presented a discrimination index similar to the control. The continuous exposure to a polluted environment could predispose the animals to neuronal damage induced by oxidative stress in a way similar to that in the myocardial cells [14]. On the other hand, there was a clear opposite effect of the exposure to air pollution on the habituation parameters. The procedural memory (habituation) parameters of animals exposed to air pollution in both pre and post-natal periods until adulthood and of those exposed only after PND21, was higher compared with the other group of rats. These data suggest that early and continuous exposure to pollutants trigger some mechanisms involved in potentializing the ability to adjust. The results from this research are in agreement with the idea that the mechanisms involved in the modulation of discriminative memory and habituation are dissimilar [42]. Nevertheless, Zanchi et al (2009) [53] have shown that adult rats which were exposed to ROFA for 30 days did not change habituation parameters evaluated by open field test. Since habituation can occur with an unlimited number of behavioral responses, this diversity hinders the establishment of a single mechanism or CNS anatomical site and the apparent conflicting results may be explained by the different paradigms employed in both studies. 
In summary, the data showed that exposure to ambient level of air pollution during pre and post-natal period impairs the short-term discriminative memory, and suggest that gestational and first childhood periods are the key for these effects. Furthermore, cortical oxidative stress may have an important role to mediate the impairment of short-term discriminative memory induced by urban pollutants. The improved habituation secondary to air pollution exposure indicates that those behaviors in which the mechanisms require more primitive physiological, anatomical and cellular processes may be potentiated in response to environmental adversity. This preliminary study opened a myriad of questions that demands further studies for elucidation. 


\section{Conflict of interest}

The authors declare that there are no conflicts of interest.

\section{Acknowledgements}

This work was supported by University of São Paulo, Federal University of Health Sciences of Porto Alegre, FAPESP (Fundação de Amparo a Pesquisa do Estado de São Paulo) and FINEP. A.C. Zanchi is supported by a fellowship from FAPESP, Dr. P.H.N. Saldiva and Dr. C.R. Rhoden supported by - Conselho Nacional de Desenvolvimento Científico e Tecnológico - CNPq. Dr. P.H.N. Saldiva and Dr. A.C. Valle are support by FAPESP. The authors declare they have no conflict of interest.

We would like to thank Dr. Elia Caldini, MSc. Nilsa Damaceno Rodrigues (Cell Biology Laboratory, Medical School, University of São Paulo); Dr. Mariangela Macchione, Dr. Mariana Matera Veras (Laboratory of Experimental Pollution - University of São Paulo). Lucas Sagrillo Fagundes, Lucianna Schmitt, Marcella Ody Piva, Maria Fernanda Hornos Carneiro, Roberto Marques Damiani and Marcelo Rafael Petry (Laboratory of Oxidative Stress and Atmospheric Pollution, Basic Health Sciences Department, Federal University of Health Sciences of Porto Alegre, RS, Brazil) for their technical support. 


\section{References}

[1] Aebi H. Catalase in vitro. Meth. Enzymol.,1984;105:121-126.

[2] Aggleton JP, Keen S, Waarburton EC, Bussey TJ. Extensive cytotoxic lesions involving both the rhinal cortices and area TE impair recognition but spare spatial alteration in the rat. Brain Research. Bull.,1997;43(3):279-287.

[3] Apostoli P, Spomenka T, Sager PR. Reproductive and developmental toxicology of metals. In: Nordberg GF, Fowler BA, Nordberg M, Friberg L. Handbook on the Toxicology of Metals. United States of America: Elsevier, 2007a, Chapter 7, p. 117-139.

[4] Batista BL, Rodrigues JL, Nunes JA, Tormen L, Curtius AJ, Barbosa FJr. Exploiting dynamic reaction cell inductively coupled plasm mass spectrometry (DRC-ICP-MS) for sequential determination of trace elements in blood using a dilute-and-shoot procedure. Anal. Chim. Acta,2009:639:1318.

[5] Bernardi R, Barros HMT. Carbamazepine enhances discriminative memory in rat model o epilepsy. Epilepsy, 2004;45(11):1443-1447.

[6] Bevins RA, Besheer J. Object recognition in rats and mice: a one trial non-matching-to-sample learning task to study "recognition memory". Nat. Prot.,2006;1(3):1306-1311.

[7] Bressler JP, Olivi L, Cheong JH, Kim Y, Maerten A, Bannon D. Metal transporters in intestine and brain:their involvement in metal-associated neurotoxicities. Hum. Exp.Toxicolol.,2007;26(3):221-229. 
[8] Buege JA, Aust SD. Microssomal lipid peroxidation. Meth. Enzymol., 1978;52:302-309.

[9] Calderón-garcidueñas L, Mora-tiscareño A, Ontiveros E, Gómez-garza G, Barragán-Mejía G, Chapman S, Valencia-Salazar G, Jewells V, Maronpot RR, Henriquez-roldán C, Pérez-Guillé B, Torres-jardón R, Herritt L, Brooks D, Osnaya-Brizuela N, Monroy MD, González-Maciel A, Reynoso-Robles R, Villarreal-Calderón R, Solt AC, Engle RW. Air pollution, cognitive deficits and brain abnormalities: a pilot study with children and dogs. Brain Cogn.,2008a;68(2):117-127.

[10] Calderón-garcidueñas L, Solt AC, Henriquez-roldán C, Torres-jardón R, Nuse B, Herritt L, Villarreal-Calderón R, Osnaya N, Stone I, García R, Brooks DM, González-Maciel A, Reynoso-Robles R, Delgado-Chávez R, Reed W. Long-term air pollution exposure is associated with neuroinflammation, an altered innate immune response, disruption of the blood-brain barrier, ultrafine particulate deposition, and accumulation of amyloid beta-42 and alpha-synuclein in children and young adults. Toxicol. Pathol.,2008b;36(2):289-310.

[11] Chakraborti A, Gulati K, Ray A. Aged related differences in stress induced neurobehavioral responses in rats: modulation by antioxidants. Behav. Brain Res.,2008;194(1): 86-91.

[12] Chater S, Douki T, Garrel C, Favier A, Sakly M, Abdelmelek H. Cadmium-induced oxidative stress and DNA damage in kidney of pregnant female rats. C.R. Biologies, 2008;331:426-432. 
[13] Chow ES, Hui MN, Lin CC, Cheng SH. Cadmium inhibits neurogenesis in zebrafish embryonic brain development. Aquat. Toxicol.,2008:87(3):157169.

[14] Damaceno-Rodrigues NR, Veras MM, Negri EM, Zanchi AC, Rhoden CR, Saldiva PHN, Dolhnikoff M, Caldini EG. Effect of pre and posnatal exposure to urban air pollution on myocardial lipid peroxidation levels in adult mice. Inhal. Toxicol., 2009;21(13):1129-1137.

[15] Dugandzic R, Dodds L, Stieb D, Smith-Doiron M. The association between low level exposures to ambient air pollution and term low birth weight: a retrospective cohort study. Environ. Health., 2006;17(5):3.

[16] Ennaceur A, Delacour J. A new one-trial for neurobiological studies of memory in rats. 1: Behavioral data. Behavioral Brain Res.,1988:31:47-59.

[17] Environmental Protect Agency. Air. In: http://www.epa.gov/; 2006.

[18] Goldim JR. Pesquisa em saúde: Leis, normas e diretrizes. Porto Alegre: Grupo de Pesquisa e Pós-Graduação, 1995.

[19] Halliwell B, Gutteridge JMC. Free Radicals in Biology and Medicine. London: Oxford University Express, 1998.

[20] Hansen CA, Barnett AG, Pritchard G. The effect of ambient air pollution during early pregnancy on fetal ultrasonic measurements during midpregnancy. Environ. Health Perspect., 2008;116(3):362-369. 
[21] Hussain S, Slikker WJr., Ali SF. Age-related changes in antioxidant enzymes, superoxide dismutase, catalase, glutathione peroxidase and glutathione in different regions of mouse brain. Int. J. Dev. Neurosci.,1995;13(8):811-817.

[22] Khan JY, Black S. Developmental changes in murine model antioxidants enzymes. Ped. Res.,2003:54(1):77-82.

[23] Kim DW, Kim KY, Choi BS, Youn P, Ryu DY, Klaassen CD, Park JD. Regulation of metal transporters by dietary iron, and the relationship between body iron levels and cadmium uptake. Arch. Toxicol.,2007;81(5):327-334.

[24] Lahiri DK, Chen D, Lahiri P, Rogers JT, Greig NH, Bondy S. Melatonin, metals and gene expression: implication in aging and neurodegenerative disorders. Ann. N. Y. Sci.,2007;1035:216-230.

[25] Lichtenfels AJF, Gomes JB, Pieri PC, Miraglia SG EI K, Hallak J, Saldiva PHN. Increased levels of air pollution and a decrease in the human and mouse male-to-female ratio in São Paulo, Brazil. Fertil. Steril.,2007;87(1):230-232.

[26] LPAE, LAPAt. Projeto de avaliação ambiental em regiões metropolitanas. São Paulo: Laboratório de Poluição Atmosférica Experimental, Laboratório de Análise de Processos Atmosféricos,2009.

[27] Marklund S, Marklund G. Involvement of the superoxide anion radical in the autoxidation of pyrogallol and a convenient assay for superoxide dismutase.Eur. J. Biochem., 1974;47:469-474. 
[28] Maroziene L, Grazuleviciene R. Maternal exposure to low level air pollution and pregnancy outcomes: a population-based study. Environmental Health: a global access science source I. In: http://www.ehjournal.net/content/1/1/6, 2002.

[29] Moshtaghie AA, Ani M, Aghadavod E, Fazilati M. Protective effects of selenium and zinco $\mathrm{n}$ changes in catecholamines levales in brain regions in lead intoxified rat. Pak. J. Biol. Sci.,2007;10(17):2694-2697.

[30] Needham LL, Barr DB, Caudill SP, Pirkle JL, Turner WE, Osterloh J, Jones RL, Sampson EJ. Concentrations of environmental chemicals associated with neurodevelopmental effects in US population. Neurotoxicology, 2005;26:531-545.

[31] Neves CMM. Lipoperoxidação no encéfalo de rato submetido à isquemia global transitória. Porto Alegre: Universidade Federal do Rio Grande do Sul, 1997.

[32] Nordberg GF, Gerhardsson L, Broberg K, Mumtaz M, Ruiz P, Fowler B. Interactions in metal toxicology. In: Nordberg GF, Fowler BA, Nordberg M, Friberg L. Handbook on the Toxicology of Metals. United States of America: Elsevier, 2007a, Chapter 7, p. 117-139.

[33] Nordberg GF, Nogawa K, Nordberg M, Friberg LT. Cadmium. In: Nordberg GF, Fowler BA, Nordberg M, Friberg L. Handbook on the Toxicology of Metals. United States of America: Elsevier, 2007b, Chapter 23, p. 117-139. 
[34] Oberdörster G, Maynard A, Donaldson K, Castranova V, Fitzpatrick J, Ausman K, Carter J, Karn B, Kreyling W, Lai D, Olin S, Monteiro-Riviere N, Warheit D, Yang $\mathrm{H}$ and a report from the ILSI Research Foundation/Risk Science Institute Nanomaterial Toxicity Screening Working Group. Principles for characterizing the potential human health effects from exposure to nanomaterials: elements of screening strategy. Particle and Fibre Toxicology, 2005a. In: www.particleanfibretoxicology.com/content/2/1/8.

[35] Oberdörster G, Oberdörster E, Oberörster J. Nanotoxicology: an emerging discipline evolving from studies of ultrafine particles. Environ. Health Perspect., 2005b;113 (7):823-839.

[36] Perera FP, Zhigang L, Whyatt R, Hoepner L, Wang S, Camann D, Rauh V. Prenatal airborne polycyclic aromatic hydrocarbon exposure and child IQ at age 5 years. Pediatrics, 2009;124(2):195-202.

[37] Pinho RA, Andrades ME, Oliveira MR, Pirola AC, Silveira PC, Dal-Pizzol F, Moreira JC. Imbalance in SOD/CAT activities in rat skeletal muscles submitted to treadmill training exercise. Cell Biol. Int.,2008;30(10):848-853.

[38] Quig D. Cysteine metabolism and metal toxicity. Altern. Med. Rev.,1998;3(4): 262-270.

[39] Rankin C. Habituation: the foundation of learning and attention, international workshop on Habituation, Vancouver. J. Neurogenet., 2008;22(1):15-16. 
[40] Saldiva PH, Lichtenfels AJ, Paiva PS, Barone IA, Martins MA, Massad E, Pereira JC, Xavier VP, Singer JM, Bohm GM. Association between air pollution due to respiratory diseases in children. Environ. Res.,1994;65:218225.

[41] Saldiva PH, Pope CA, Shwarz J, Dockery DW, Lichtenfels AJ, Salge JM, Barone I, Bohm GM. Air pollution and mortality in elderly people: a timeseries study in São Paulo, Brazil. Arch. Environ. Health., 1995; 50:159-163.

[42] Salomons AR, van Luijk JA, Reinders NR, Kirchhoff S, Arndt SS, Ohl F. Identifying emotional adaptation: behavioral habituation to novelty and immediate early gene expression. Genes Brain Behav., 2009; in press.

[43] Schleicher E, Wieland OH. Evaluation of Bradford method for protein determination in body fluids. J. Clin. Chem. Clin. Biochem.,1978;16(9):533534.

[44] Shukla A, Shukla GE, Srimal RC. Cadmium-induced alterations in bloodbrain barrier permeability and its possible correlation with decreased microvessel antioxidant potential in rat. Hum. Exp. Toxicol.,1996;15(5):400405.

[45] Squire LR, Kandel ER. Memória: da mente às moléculas. Porto Alegre: Artmed, 2003.

[46] Suglia SF, Gryparis A, Wright RO, Schwartz J, Wright RJ. Association of black carbon with cognition among children in a prospective cohort study. Am. J. Epidemiol., 2008;167:280-286. 
[47] Sunyer J. The neurological effects of air pollution in children, Eur. Resp. J.,2008; 32:535-537.

[48] Takeda A. Movement of zinc and its functional significance in the brain. Brain Res. Brain Res. Rev., 2000;34(3):137-148.

[49] Thompson RF. O cérebro: uma introdução à neurociência. São Paulo: Livraria Santos Editora, 2005.

[50] Tietze F. Enzymic method for quantitative determination of nanogram amounts of total and oxidized glutathione: applications to mammalian blood and other tissues. Anal. Biochem.,1969;27:502-522.

[51] Veras MM, Damaceno-Rodrigues NR, Caldini EG, Ribeiro AACM, Mayhew TM, Saldiva PHN, Dolhnikoff M. Particulate urban air pollution affects the functional morphology of mouse placenta. Biol. Reprod.,2008:79:578-584.

[52] Wang L, Cao J, Chen D, Liu X, Lu H, Liu Z. Role of oxidative stress, apoptosis and intracellular homeostasis in primary cultures of rat proximal tubular cells exposed to cadmium. Biol. Trace Elem. Res., 2009;127(1):5368.

[53] Zanchi AC, Saiki M, Saldiva PHN, Barros HMT, Rhoden CR. Hippocampus lipid peroxidation induced by Residual Oil Fly-Ash inhalation versus cognitive changes: An experimental study. Inhal. Toxicol., 
[54] Zanchi AC, Venturini C, Saiki M, Saldiva PHN, Barros HMT, Rhoden CR. Chronic nasal Instillation of Residual-Oil Fly Ash (ROFA) induces brain lipid peroxidation and behavioral changes in rats. Inh. Toxicol., 2008;20:795-800. [55] Zheng W, Aschner M, Ghersi-Egea JF. Brain barrier systems: a new frontier in metal neurotoxicological research. Toxicol. Appl. Pharmacol., 2003:192:1-11.

[56] Xia T, Kovochich M, Nel A. The role of reactive oxygen species and oxidative stress in mediating particulate matter injury. Clin. Occup. Environ. Med. 2006;5(4) 817-36. 


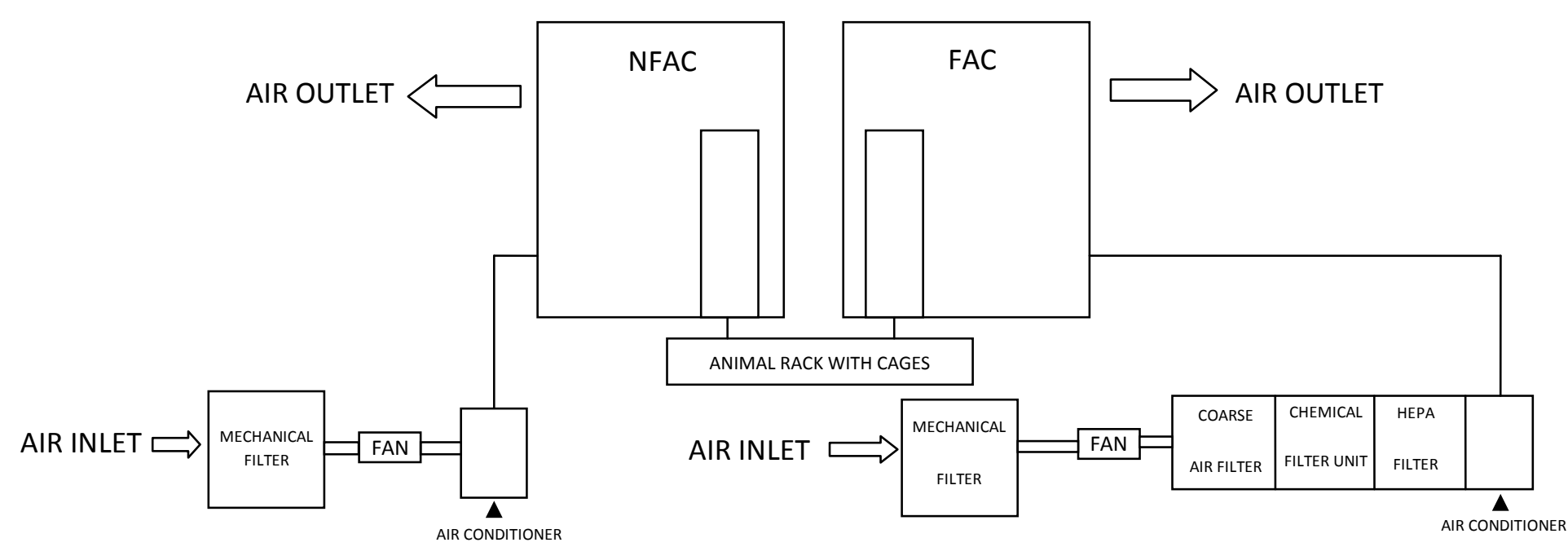

Figure 1. Chambers structure. NFAC (non-filtered air chamber); FAC (filtered air chamber). 


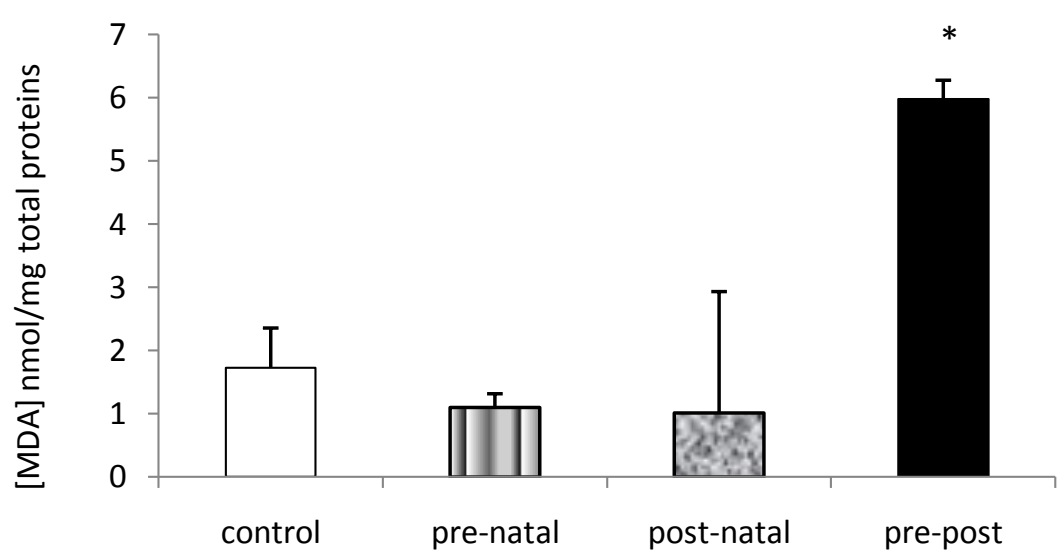

Groups

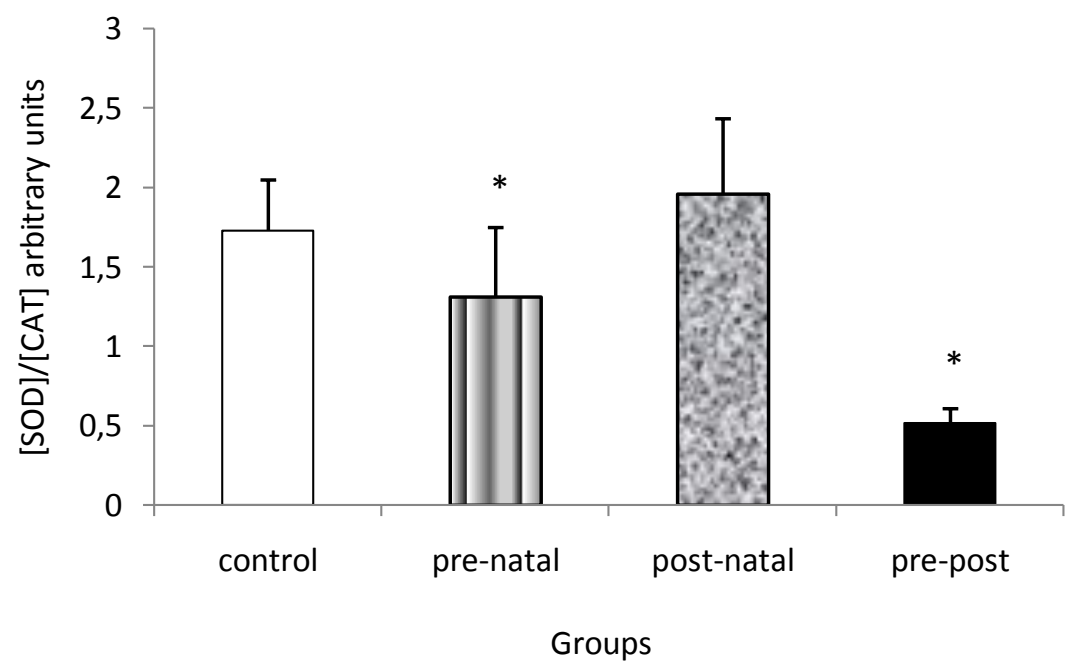

B

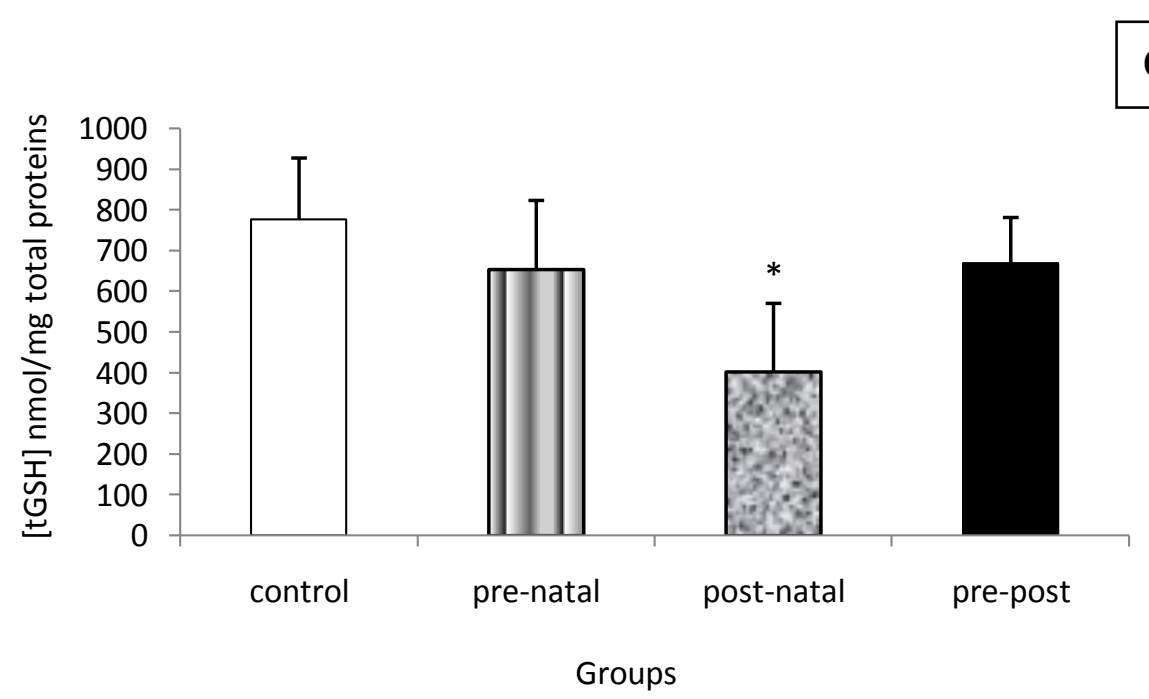


Figure 2: Oxidative stress in cortex of rats exposed to ambient level of air pollution. Groups: control: pre and post-natal in filtered air; pre-natal: pre-natal in non-filtered air until PND21 and post-natal in filtered air until adulthood; post-natal: pre-natal in filtered air until PND21 and post-natal in non-filtered air until adulthood; pre-post: pre and post-natal in nonfiltered air. Values represent the mean of 12 rats per group \pm SEM. ANOVA - One Way followed by post hoc Student Newman Keuls: A: [MDA] nmol/mg proteínas totais, ${ }^{*} \mathrm{P}=0.007$; $F_{(3 ; 26)}=5.219$ when compared pre-post to control, pre-natal and post-natal groups; $B$ : [SOD]/[CAT] ratio, ${ }^{*} \mathrm{P}=0.046$ when compared pre-natal to pre-post; $\mathrm{C}$ : [tGSH] nmol/total proteins, ${ }^{*} \mathrm{P}=0.003 ; \mathrm{F}_{(3 ; 24)}=6.464$ when compared post-natal to control, pre-natal, and prepost groups. 


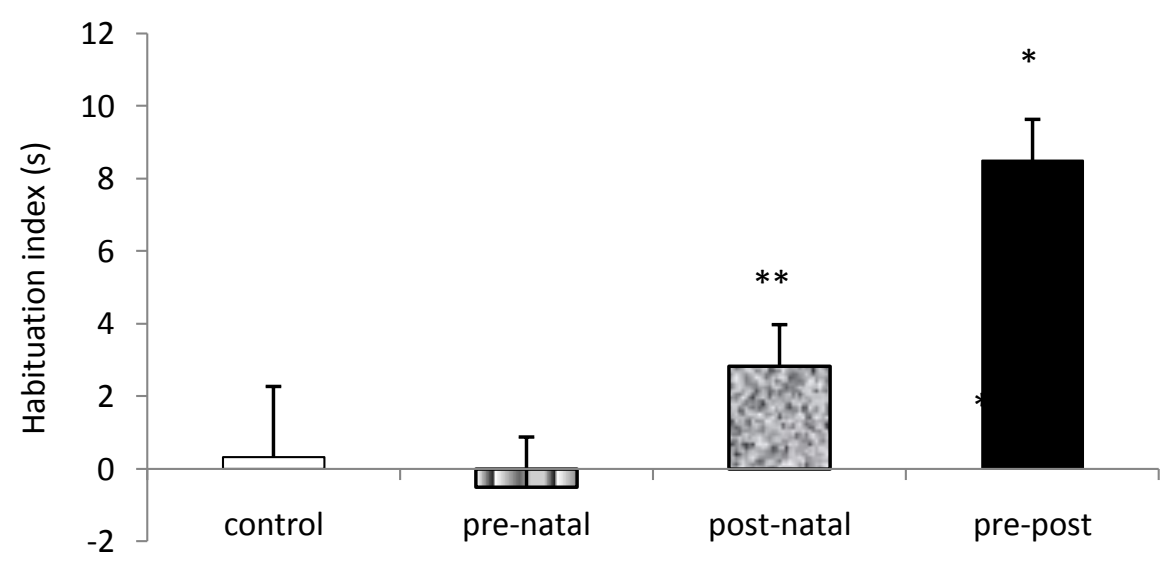

Groups

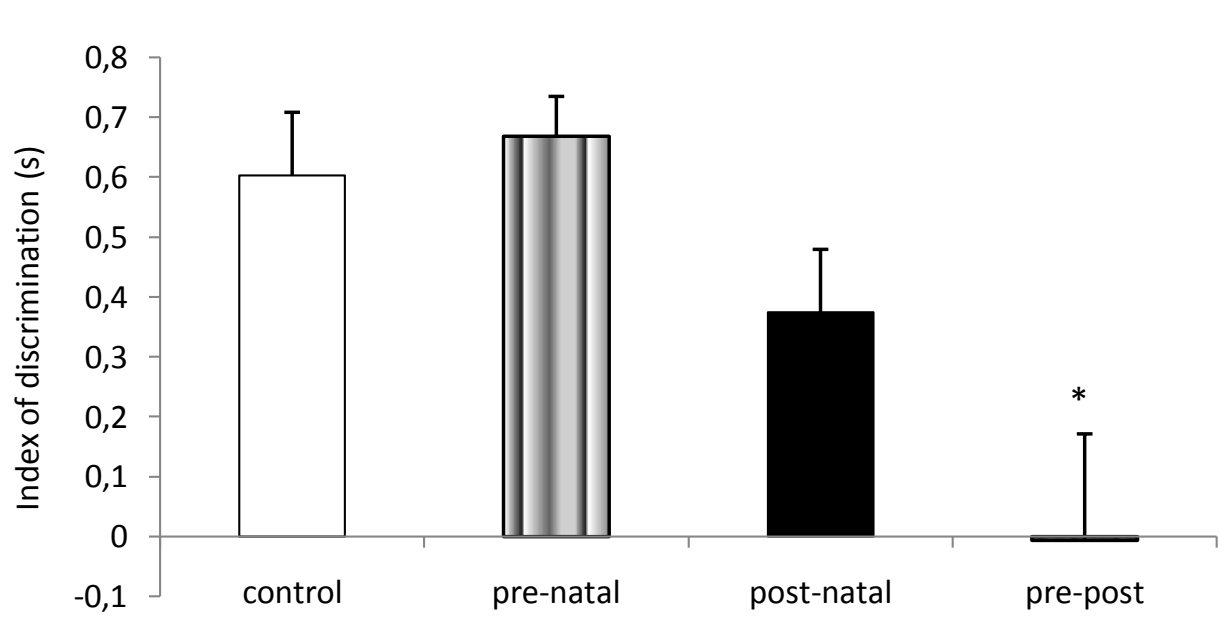

Groups

Figure 3: Indexes of short-term discriminative memory and habituation of rats exposed to ambient level of air pollution. Groups: control: pre and post-natal in filtered air; pre-natal: pre-natal in non-filtered air until PND21 and post-natal in filtered air until adulthood; post-natal: pre-natal in filtered air until PND21 and post-natal in non-filtered air until adulthood; pre-post: pre and post-natal in non-filtered air. Values represent the mean of 12 rats per group \pm SEM. ANOVA-One Way followed by post hoc Student Newman Keuls to compare the habituation to test environment and discrimination indexes of control, pre-natal, post-natal and pre-post groups: A: habituation (s), ${ }^{*} \mathrm{P}=0.001 ; \mathrm{F}_{(3 ; 30)}=4.197$ when compared pre-post to control, pre-natal and post-natal; $B$ : discrimination index (s), ${ }^{*} P=0.006 ; F_{(3}$; 23) $=5.479$ when compared pre-post to control, pre-natal and post-natal. ANOVA - Two Way ANOVA followed all pair wise multiple comparison procedures (Student-Newman-Keuls test) was used to determine the interaction between the place of birth and change of environment after PND21 to index of habituation as the dependent variable when compared post-natal to control, pre-natal and post-natal: ${ }^{* *} P=0.035$ (there is an interaction between the place of birth and change of environment). ANOVA - two way analyses was used to determine the interaction between the place of birth and change of environment after PND21 to the index of 
discrimination as dependent variable: there was no interaction between these two parameters $(\mathrm{P}=0.095)$. 
Table 1: Litters development parameters

\begin{tabular}{|c|c|c|c|}
\hline Development parameters & FAC & NFAC & $P$ \\
\hline Total number of pups & $8.7 \pm 0.603$ & $8.8 \pm 0.526$ & $\mathrm{P}=0.691^{\mathrm{a}}$ \\
\hline $\begin{array}{c}\text { Number of post-natal } \\
\text { deaths }\end{array}$ & 0 & 0 & $\mathrm{P}=1.000^{\mathrm{a}}$ \\
\hline Time to open their eyes & $13.771 \pm 0.646$ & $13.200 \pm 0.569$ & $\mathrm{P}=0.565^{\mathrm{a}}$ \\
\hline $\begin{array}{c}\text { Time to emerge the first } \\
\text { bristles }\end{array}$ & $8.373 \pm 0.527$ & $7.864 \pm 0.417$ & $\mathrm{P}=0.461^{\mathrm{a}}$ \\
\hline Litters Weight (g): day 0 & $55.000 \pm 3.441$ & $55.000 \pm 3.839$ & $\mathrm{P}=1.000^{\mathrm{a}}$ \\
\hline Litters Weight (g): day 7 & $108.750 \pm 8.750$ & $114.500 \pm 6.229$ & $\mathrm{P}=0.596^{\mathrm{a}}$ \\
\hline \multirow[t]{2}{*}{ Pup mean Weight (g) } & Weight $_{\text {FAC }(0)}: 6.587 \pm 0.224$ & Weight $_{\text {NFAC (o) }}: 6.230 \pm 0.368$ & $\mathrm{P}=0.413^{\mathrm{a}}$ \\
\hline & Weight $_{\text {FAC }(7)}: 12.485 \pm 0.605$ & Weight $\operatorname{NFAC}(7): 13.160 \pm 0.459$ & $\mathrm{P}=0.379^{\mathrm{a}}$ \\
\hline \multirow{2}{*}{$\begin{array}{c}\text { Number of females and } \\
\text { males }\end{array}$} & $\mathrm{FAC}_{\text {(females) }}: 3.978 \pm 0.427$ & $\mathrm{NFAC}_{\text {(females) }}: 4.333 \pm 0.427$ & \multirow[t]{2}{*}{$\mathrm{P}=0.891^{\mathrm{b}}$} \\
\hline & $\mathrm{FAC}_{\text {(males) }}: 4.022 \pm 0.341$ & $\mathrm{NFAC}_{\text {(males) }}: 3.944 \pm 0.380$ & \\
\hline
\end{tabular}

Values were expressed in mean \pm SEM. ${ }^{\text {a }}$ Student $t$ test: to compare the development puppies parameters between FAC (filtered air chamber) and NFAC (non-filtered air chamber); ${ }^{a}$ Student $t$ test to compare total number of pups, number of post-natal deaths, time to open their eyes (in days), time to emerge the first bristles (in days) from FAC and NFAC. Student $t$ test to compare weight ${ }_{F A C}(0)$ (weight of pup at day 0 in FAC with weight NFAC (0) (weight of pupa $t$ day 0 in NFAC); weight FAC (7) (weight of pup at day 7 in FAC with weight NFAC (7) (weight of pupa t day 7 in NFAC) ${ }^{b}$ One way ANOVA to compare number of females and males in both chambers: $F A C_{\text {(females) }}$ (number of females from filtered air chamber), $\mathrm{NFAC}_{\text {(females) }}$ (number of females from non-filtered chamber), $\mathrm{FAC}_{\text {(males) }}$ (number of males from filtered chamber) and $\mathrm{NFAC}_{\text {(males) }}$ (number of males from non-filtered chamber). There were no significant differences between pups development parameters from both chambers, $P>0.05$. 
Table 2: Total monthly $\mathrm{PM}_{2.5}$ mass.

\begin{tabular}{l|c|c}
\hline Year & Month & $\mathrm{PM}_{2.5}\left(\mu \mathrm{g} / \mathrm{m}^{3}\right.$ air $)$ \\
\hline 2008 & February & $9.6 \pm 1.6$ \\
& March & $14.1 \pm 5.7$ \\
& April & $15.7 \pm 8.4$ \\
& May & $26.7 \pm 19.2$ \\
& June & $14.5 \pm 12.6$ \\
\hline
\end{tabular}

Values were expressed as mean \pm Std. 
Table 3. Trace elements concentrations determined by X-Ray fluorescence of samples colected in polycarbonate filters in Porto Alegre.

\begin{tabular}{l|l|l}
\hline Year 2008 & Trace elements & Concentration $\left(\mathrm{ng} / \mathrm{m}^{3}\right.$ air $)$ \\
\hline Porto Alegre & $\mathrm{Mg}$ & $40.5 \pm 28.8$ \\
(N=134) & $\mathrm{Al}$ & $39.9 \pm 33.0$ \\
& $\mathrm{Si}$ & $75.2 \pm 94.9$ \\
& $\mathrm{P}$ & $5.8 \pm 6.3$ \\
$\mathrm{~S}$ & $383.4 \pm 355.8$ \\
$\mathrm{Cl}$ & $54.5 \pm 113.7$ \\
$\mathrm{~K}$ & $227.4 \pm 266.5$ \\
$\mathrm{Ca}$ & $36.1 \pm 35.7$ \\
& $\mathrm{Ti}$ & $3.9 \pm 4.2$ \\
$\mathrm{~V}$ & $0.7 \pm 0.8$ \\
$\mathrm{Cr}$ & $1.0 \pm 2.2$ \\
$\mathrm{Mn}$ & $2.8 \pm 3.3$ \\
& $\mathrm{Fe}$ & $63.9 \pm 63.3$ \\
& $\mathrm{Co}$ & ----- \\
& $\mathrm{Ni}$ & $0.7 \pm 1.6$ \\
& $\mathrm{Cu}$ & $2.6 \pm 4.0$ \\
& $\mathrm{Zn}$ & $14.9 \pm 19.5$ \\
& $\mathrm{Se}$ & $1.4 \pm 1.1$ \\
& $\mathrm{Br}$ & $2.4 \pm 2.4$ \\
& $\mathrm{~Pb}$ & $5.8 \pm 5.5$ \\
\hline
\end{tabular}

Values were expressed as Mean \pm Std. 
Table 4: Essential trace elements blood concentration of rats exposed to ambient level of air pollution.

\begin{tabular}{c|l|l|c}
\hline Trace elements & \multicolumn{1}{|c|}{ Groups } & \multicolumn{1}{|c}{ Concentration $(\mu \mathrm{g} / \mathrm{L})$} & $\mathrm{P}$ \\
\hline $\mathrm{Cd}$ & Control & $0.133 \pm 0.0516$ & 0.005 \\
& Pre-natal & $0.217 \pm 0.0983$ & $\mathrm{~F}_{(3 ;}$ \\
& Post-natal & $0.293 \pm 0.0750^{*}$ & $23)=5.870$ \\
& Pre-post & $0.283 \pm 0.0659^{* *}$ & \\
\hline $\mathrm{Pb}$ & Control & $1.983 \pm 1.113$ & 0.496 \\
& Pre-natal & $2.650 \pm 2.214$ & $\mathrm{~F}_{(3 ;}$ \\
& Post-natal & $3.817 \pm 3.022$ & $23)=0.823$ \\
& Pre-post & $2.650 \pm 1.290$ & \\
\hline
\end{tabular}

Values were expressed as mean \pm Std. ANOVA One Way followed by Student Newman Keuls to compare control, pre-natal, post-natal and prepost groups: "significant difference between post-natal and control groups; ${ }^{* *}$ significant difference between pre-post and control groups. 
Table 5: Non-essential trace elements blood concentration of rats exposed to ambient level of air pollution.

\begin{tabular}{|c|c|c|c|}
\hline $\begin{array}{l}\text { Non-essential } \\
\text { trace elements }\end{array}$ & Groups & Concentration $(\mu \mathrm{g} / \mathrm{L})$ & $\mathrm{P}$ \\
\hline $\mathrm{Cu}$ & $\begin{array}{l}\text { Control } \\
\text { Pre-natal } \\
\text { Post-natal } \\
\text { Pre-post }\end{array}$ & $\begin{array}{l}927.833 \pm 145.074 \\
1148.500 \pm 89.229^{*} \\
1002.833 \pm 90.418 \\
908.667 \pm 34.500\end{array}$ & $\begin{array}{c}0.002 \\
F_{(3 ; 23)}=7.416\end{array}$ \\
\hline $\mathrm{Mn}$ & $\begin{array}{l}\text { Control } \\
\text { Pre-natal } \\
\text { Post-natal } \\
\text { Pre-post }\end{array}$ & $\begin{array}{l}13.633 \pm 4.878 \\
15.500 \pm 5.244 \\
9.867 \pm 2.267 \\
9.767 \pm 5.148\end{array}$ & $\begin{array}{c}0.104 \\
F_{(3 ; 23)}=2.345\end{array}$ \\
\hline Se & $\begin{array}{l}\text { Control } \\
\text { Pre-natal } \\
\text { Post-natal } \\
\text { Pre-post }\end{array}$ & $\begin{array}{l}407.333 \pm 74.712 \\
535.333 \pm 17.317^{\star} \\
449.167 \pm 61.655 \\
404.333 \pm 40.471 \\
\end{array}$ & $\begin{array}{c}0.001 \\
F_{(3 ; 23)}=7.904\end{array}$ \\
\hline $\mathrm{Zn}$ & $\begin{array}{l}\text { Control } \\
\text { Pre-natal } \\
\text { Post-natal } \\
\text { Pre-post }\end{array}$ & $\begin{array}{l}5674.833 \pm 720.524 \\
7145.000 \pm 268.274^{*} \\
6274.500 \pm 664.331 \\
5958.500 \pm 478.797\end{array}$ & $\begin{array}{c}0.001 \\
F_{(3 ; 23)}=7.715\end{array}$ \\
\hline
\end{tabular}

Values were expressed as mean \pm Std. ANOVA One Way followed by Student Newman Keuls to compare control, pre-natal, post-natal and prepost groups: Cu: *significant difference between pre-natal and post-natal; pre-natal and control; pre-natal and pre-post groups; Se: *significant difference between pre-natal and post-natal; pre-natal and control; pre-natal and pre-post groups; $\mathrm{Zn}$ : "significant difference between pre-natal and postnatal; pre-natal and control; pre-natal and pre-post groups. 